\title{
Animal Communities of the Level Sea-bottom in the Waters adjacent to Plymouth.
}

\author{
By \\ E. Ford, A.R.C.Sc., \\ Naturalist at the Plymouth Laboratory. \\ With 1 Chart, and 6 Figures in the Text.
}

From May, 1922, onwards the $\frac{1}{10}$ sq. metre bottom-sampler has been used to collect samples of the bottom-deposits with their animals, in the waters off Plymouth. The animals have been removed as soon as possible after capture by passing the samples through a series of sieves, and have been preserved in alcohol, to be identified and counted ashore. The present report deals with the distribution of the species represented, in the light of Petersen's Community investigations in Danish waters.

I express my thanks to Dr. Allen, Dr. Orton, Mr. Hunt, and Mr. Smith, of the Plymouth Laboratory, for their kind help in the identification of the material. I am particularly indebted to my friend, Mr. R. Winckworth, a late member of the staff, who has not only gone over with me the bulk of my collection of lamellibranchs, but has provided me with an excellent type series as complete as the material would allow.

The extensive use of his bottom-sampler in Danish waters and elsewhere has enabled Dr. C. G. Joh. Petersen to advance an opinion that " as a rule it is best to regard the animals living on the sea-bottom as communities, just as botanists group together the vegetation of the land into plant communities, even though in the present state of our knowledge it is impossible to show how intimate the mutual relations are between the animals of the sea in the single cases."

It will probably assist the reader if I commence with a short summary recalling the more important points, concerning the recognition of communities, which have been advanced by Petersen, and in doing so I shall adhere closely to his own words.

When dealing with animal life on the sea-bottom distinction must be made between two classes :-

(i) The animals of the level sea floor which, with the exception of the predatory species, live as a rule buried in the bottom.The Fauna of the Level Bottom or Infauna.

(ii) The animals which live upon or are attached to other objects.The Epifauna. 
The animals taken in the bottom-sampler from the Level Bottom are not of equal importance either for characterisation of a community as such, or for characterisation of the outer conditions on which the existence of that community is dependent. Some species are seasonal, only occurring in quantity at certain times of the year; others, which may be regarded as attendant species, may be found at greatly varying depths and in very different communities, often in considerable numbers; others occur so sparsely in the hauls that they must be considered as being so scarce that they only exceptionally come into the small areas investigated, and no importance can therefore be attached to their absence or presence. The animals which are not seasonal, and which compose an important part of the whole mass of a community, owing to number or weight, will presumably be best suited for characterising the community and must also be considered as giving a good idea of the outer conditions on which the community is dependent. It necessarily follows, then, that only by experience gained from different places can these characteristic species be determined. A limited number of the characteristic species may be selected quite arbitrarily, and their names, or convenient abbreviations, utilised for the naming of the animal communities for which they are characteristic. By means of some 10-12 such species, Petersen has enumerated 9 communities on the level bottom in Danish waters $(6$, page 13); but for present purposes attention may be restricted to 5 of these :-

1. The Macoma or Baltic community, d.

Macoma baltica, d, Cardium edule, Mya arenaria, and Arenicola marina are the most evenly distributed species.

2. The Abra community, $\mathrm{b} \pm \mathrm{E}$.

Abra alba, b, is the main characteristic species, but at times Macoma calcarea, c, and Astarte sp. a, may be present in great numbers. Echinocardium cordatum, E., as the signs indicate, may be present or absent.

3. The Venus community, $\mathrm{v} \pm \mathrm{E}$.

Characterised by Venus gallina, $v$, Tellina fabula, and several other allied sand-dwelling lamellibranchs. As in 2, Echinocardium cordatum may be present or absent.

4. The deep Venus community, (v).

Related to 3, but Echinocardium cordatum is replaced by E. flavescens, and Spatangus purpureus, while Psammobia faerœensis, Abra prismatica, and Mactra elliptica occur. This community is only feebly represented in Danish waters, and has not therefore received such detailed attention as the remainder. 
5. The Echinocardium-filiformis community, E. fil.

Echinocardium cordatum, E., and Amphiura filiformis fil., are the leading species, but Turritella terebra $\mathrm{T}$, is very often present. Indeed, in the earlier work Turritella was utilised instead of Amphiura filiformis for the descriptive name of this community.

The occurrence of these communities is dependent on the depth and degree of shelter and enclosure of the water area (5, page 9) :-

In the MORE SHELTERED waters, $d$ communities occur nearest to land, which may be followed by $\mathrm{v}$, or E.v, although frequently these last-named animals may be outnumbered by Abra alba b, or Macoma calcarea c, and in the Danish Belts and Western Baltic, by the Astarte species a.

In open WATER from the coast out to greater depths, $\mathrm{v} \pm \mathrm{E}$ communities are followed by E. fil.

In more CLOSED waters, from the coast outwards, $\mathrm{d}$ communities are followed by $\mathrm{b} \pm \mathrm{E}$, and these by $\mathrm{c} \pm \mathrm{E}$.

Having identified the communities in Danish and neighbouring waters, Petersen has directed his attention to the consideration of the distribution of animals in other areas, and has arrived at the conclusion that very similar communities to those discovered in Denmark occur in fardistant waters, and in Chart I attached to Appendix to Report XXI from the Danish Biological Station he has given a graphic prediction of the distribution of his animal communities in waters outside the Danish area, which he submits as a rough skeletal basis. In the communities he has utilised, however, he has ignored various subdivisions known to him from Danish waters, and the Abra, Venus and deep Venus communities (above) are in consequence grouped together under one main heading of Venus Communities with Spatangidæ. More recent work, also, has resulted in the suggested addition of two further communities, one, the E. fil., to be included as the next deepest community to the Venus group (6, page 13). Interpreting the chart, then, on the broadest lines, it would indicate that the level bottom in the waters off Plymouth is populated chiefly by Venus communities with, however, some representation of $\mathrm{E}$. fil., as well as a possible influence from the little known Lusitanian group. It would also be fair to expect the Macoma community to be represented on the shore areas of Plymouth Sound, although the chart does not actually indicate this, probably owing to the limitations imposed by the small scale of the drawing.

I may now conveniently proceed to the study of the results of the actual 


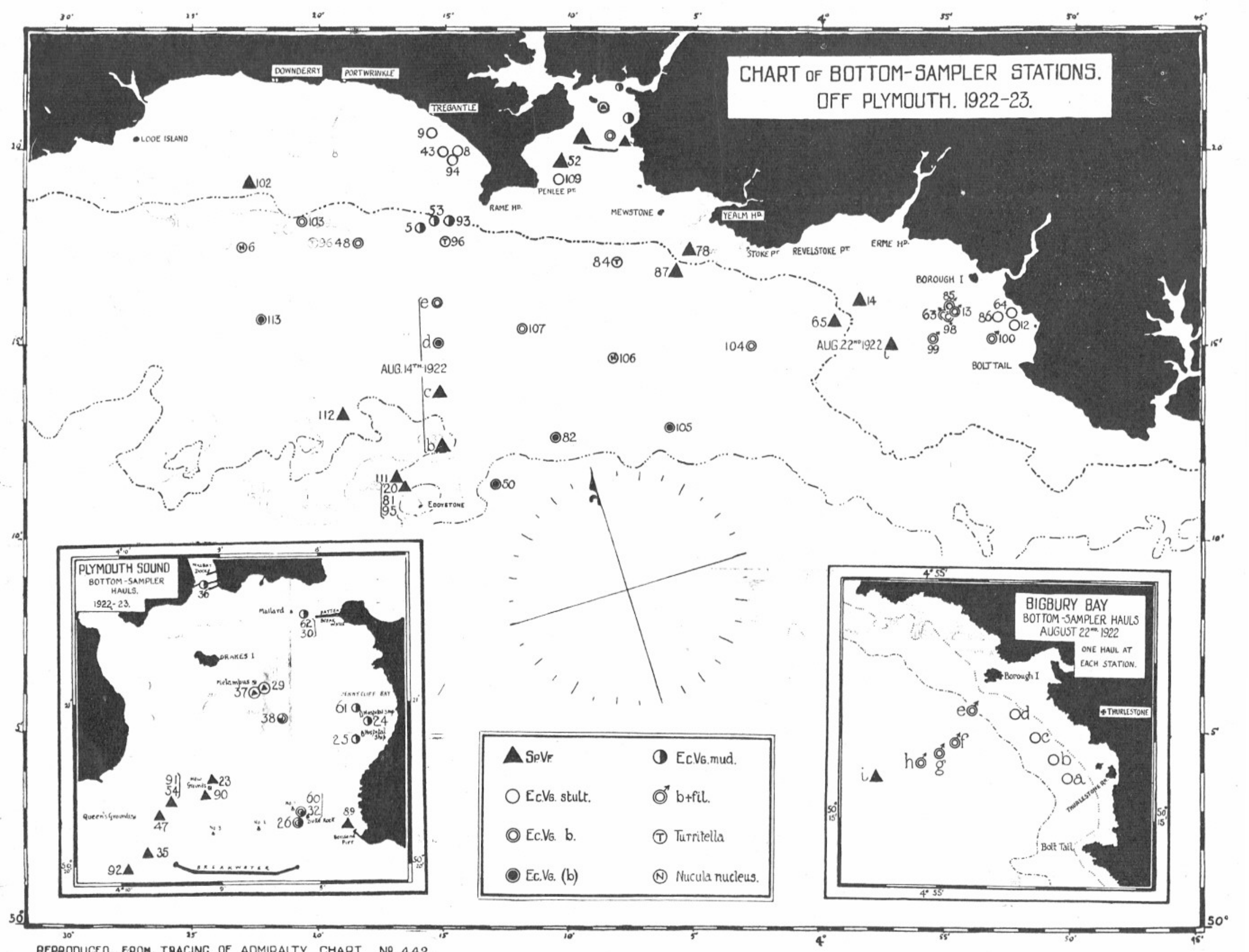

REPRDDUCEO FROM TRACING OF ADMIRALTY CHART NO 442 . 
working of the bottom-sampler in the Plymouth area, the extent of which is shown on the accompanying Charts.

In the first place, it will be seen that the Plymouth Breakwater practically shuts off the Sound from the more open Channel waters, so that, in accordance with experience in Danish waters, the effects of this enclosure should be reflected in the constitution of the respective animal communities. It is, therefore, of interest to note that the leading Spatangids, Echinocardium cordatum, Spatangus purpureus, and Echinocardium favescens do not occur characteristically anywhere in the Sound, whereas they are regularly met with in the open Channel-in the case of Echinocardium cordatum from the shore outwards to the limits of the area. Again, outside the Breakwater varying degrees of sheltering are exhibited, so that a corresponding variation in community variation should be evident. With regard to the sea-bottom itself, there is the most important factor that the bottom deposits both in the Sound and outside are far from being uniform either in texture or in the distribution of the various grades of texture. Leaving out of account such questions as to what extent differences in bottom soil in themselves control animal distribution, or to what degree such differences are merely the expression of other influences such as tides and currents, there can be no doubt that this variation and "patchiness" of the bottom deposits add very considerably to the difficulties in determining a satisfactory faunistic picture. Variation in soil involves changes in the efficiency of the bottomsampler, and on such stony ground as may be met with, for instance, on the Looe-Eddystone fishing grounds, the latter instrument is almost useless. "Patchiness" in ground necessitates many more hauls than would be necessary on a uniform bottom to ensure that nothing of importance is being overlooked; a number of instances could be given from the work now under review, where a slight alteration in the position of the ship has resulted in a most striking change, both in the nature of deposit and the proportion of the animals contained in the successive hauls of the bottom-sampler. With regard to the fauna, it is noticeable that a number of species generally occurring together in one particular kind of soil become split up into smaller groups under other bottom conditions. Thus, then, if one accepts the conception of animal communities, one must be prepared in practice to discover, on uneven ground as regards bottom soil, fewer or more groups of possibly quite different kinds of animals, while the typical community formation may only occur in localised areas. It is just this experience which leads me to suggest that clearly defined information as to the general constitution of a community, as well as its leading characteristic species, is necessary in order that the smaller groups due to " non-typical " conditions may be correctly identified. 
From the results so far obtained I am of the opinion that at least two distinct main series of level bottom animals exist alongside one another in Plymouth waters, the one expressing itself in several recognisable forms in deposits in which fine grades predominate, and the other being restricted to coarser soil, with its typical form restricted to clean shell-gravel. Adopting the system of soil-grading utilised by Allen (1, page 378), it may be stated that the first series is found where Grades VI, VII, and VIII predominate ; and the second where Grades II, III, and IV are of the greatest importance, and consist largely of shell fragments. That the difference between these series is a real one is shown by the fact that each has its own characteristic spatangids and lamellibranchs, which do not occur in the other. For the reason already given above, Table 1 has been drawn up purposely to show fairly fully the species which have proved most useful in the recognition of the two series and of the various smaller groups met with in the general survey of the grounds. The selection of the species has been governed by three factors : their facility in identification, their relative abundance, and their observed distribution.

The choice of specific names raised some difficulty, but it was eventually decided to adhere to the name recorded in the published fauna lists of the Marine Biological Association, where references are given to good descriptions of the animals concerned, and supplementing, when neces sary, from well-known and accessible works. The names utilised will therefore be found in one or other of the following:-

1. Plymouth Marine Invertebrate Fauna.-Journ. Mar. Biol. Assoc., Vol. VII, No. 2, 1904.

2. Polychaeta of Plymouth and the South Devon Coast, including a list of the Archiannelida.-E. J. Allen, Journ, Mar. Biol. Assoc., Vol. X, No. $4,1915$.

3. List of British Marine Mollusca and Branchiopoda.-Journal of Conchology, Vol. 10, No. 1, 1901.

4. Gammaridea.-T. R. R. Stebbing, Das Tierreich. Lief 21, 1906.

5. Crustacea of Norway.-G. O. Sars.

6. History of British Stalk-eyed Crustacea.-T. Bell.

7. Faune de France-Échinodermes.-R. Kœhler, 1921.

It is a little unfortunate that the specific names adopted are not in complete agreement with those used by Petersen, and in order to avoid confusion, the following important differences should be noted :- 


\begin{tabular}{|c|c|}
\hline Names used in present work. & Names used by Petersen. \\
\hline $\begin{array}{l}\text { Syndosmya alba (Wood). } \\
\text { Syndosmya prismatica (Montagu) } \\
\text { Thyasira flexuosa (Montagu). } \\
\text { Tellimya ferruginosa (Montagu) } \\
\text { Spisula elliptica (Brown). } \\
\text { Spisula subtruncata (da Costa). } \\
\text { Gari ferroensis (Chemnitz). } \\
\text { Cultellus pellucidus (Pennant). } \\
\text { Ensis ensis (Linnæus). } \\
\text { Turritella communis (Lamarck.) }\end{array}$ & $\begin{array}{l}\text { Abra alba. } \\
\text { Abra prismatica. } \\
\text { Axinus flexuosus. } \\
\text { Montacuta ferruginosa. } \\
\text { Mactra elliptica. } \\
\text { Mactra subtruncata. } \\
\text { Psammobia faeroensis. } \\
\text { Solen pellucidus. } \\
\text { Solen ensis. } \\
\text { Turritella terebra. }\end{array}$ \\
\hline
\end{tabular}

TABLE 1

\begin{tabular}{|c|c|c|}
\hline Series A. & $\begin{array}{l}\text { Species occurring in both } \\
\text { classes of soil. }\end{array}$ & Series B. \\
\hline $\begin{array}{l}\text { Typical animals found in } \\
\text { bottom deposits in which } \\
\text { grades VI, VII, and VIII } \\
\text { predominate. }\end{array}$ & & $\begin{array}{l}\text { Typical animals found in } \\
\text { bottom deposits in which } \\
\text { shelly gravel of grades II, } \\
\text { III, and IV predominates. }\end{array}$ \\
\hline $\begin{array}{l}\text { Nucula nitida } \\
\\
\text { Thyasira flexuosa } \\
\text { Montacuta bidentata } \\
\text { Tellimya ferruginosa } \\
\text { SYNDOSMYA ALBA* } \\
\text { SYNDOSMYA } \\
\text { PRISMATICA* } \\
\text { TELLINA FABULA* } \\
\text { Donax vittatus } \\
\text { Mactra stultorum } \\
\text { SPISULA } \\
\text { SUBTRUNCATA* } \\
\text { Lutraria elliptica }\end{array}$ & $\begin{array}{l}\text { *SPISULA } \\
\text { ELLIPTICA } \rightarrow \\
\stackrel{\text { Dosinia lupina }}{\text { Dosinia exoleta } \rightarrow} \\
\text { Venus (Timoclea) ovata } \\
\text { Tapes virgineus } \rightarrow\end{array}$ & $\begin{array}{l}\text { Amphioxus lanceolatus } \\
\text { Nucula radiata } \\
\text { Glycimeris glycimeris } \\
\text { Lima loscombi } \\
\text { Montacuta substriata } \\
\\
\text { Tellina crassa } \\
\text { Tellina pusilla }\end{array}$ \\
\hline
\end{tabular}

NorE.-The arrow-head opposite certain species in middle column indicates the series to which there is a tendency.

* The species in bolder type are characteristic species for certain of Petersen's com munities. 
TABLE 1-continued.

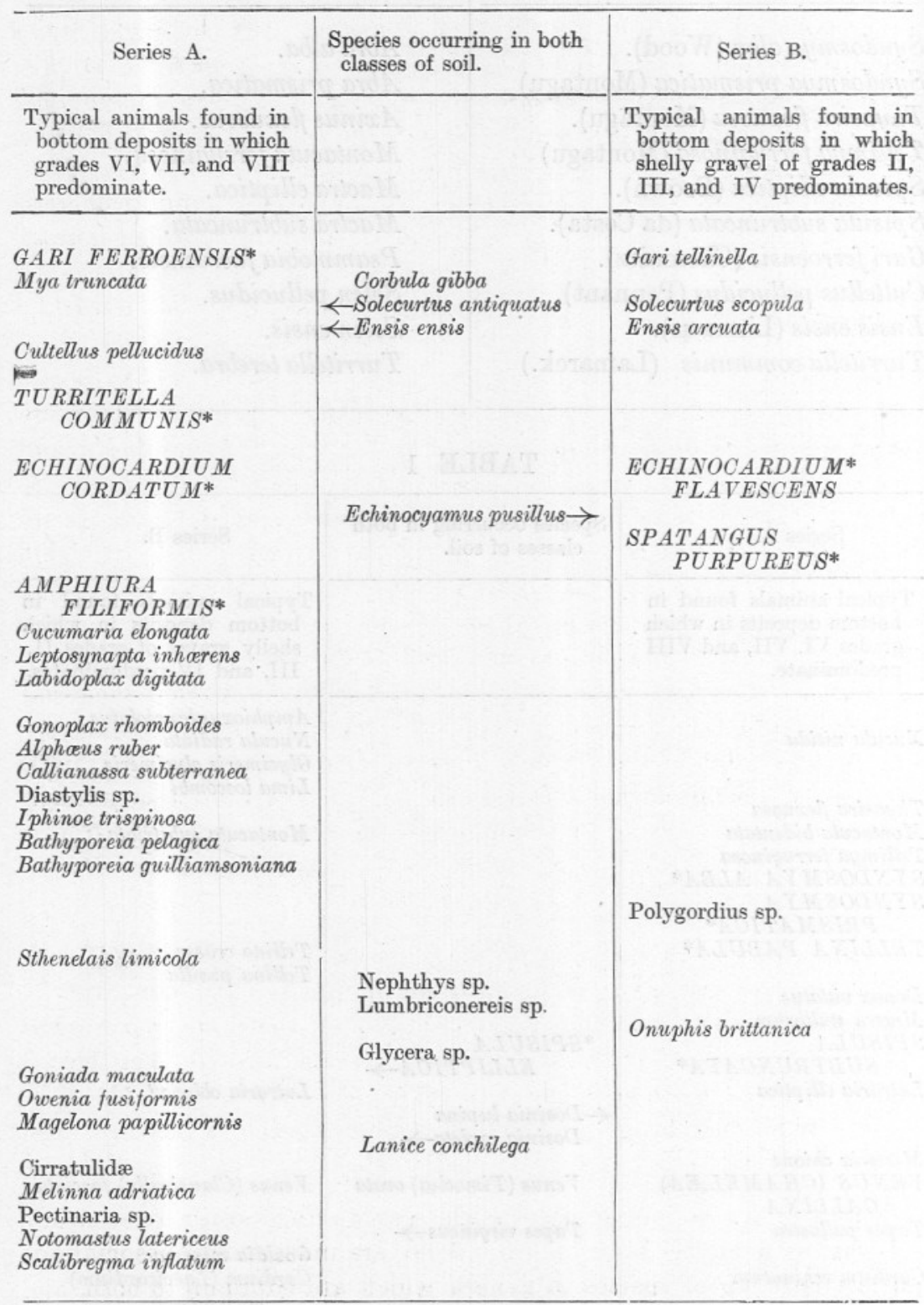

Note.-The arrow-head opposite certain species in middle column indicates the series to which there is a tendency.

* The species in bolder type are characteristic species for certain of Petersen's com. munities. 
Some explanation is necessary with regard to the species which are shown in the table as occurring in both kinds of soil. It is naturally to be expected that some overlapping will occur, and the arrow-heads opposite certain species indicate to which series present experience suggests that the species should be referred. A number of animals, however, appear regularly and commonly in both series, e.g. Corbula gibba, which may be reasonably regarded as the equivalent of Petersen's attendant species. Such polychaetes as Nephthys, Lumbriconereis, and Glycera present difficulties in specific identification which detract from their value as possible type forms, so that their prevalence on certain stations cannot be made of as much use as could be desired.

With the two series thus set out it is convenient to make a first comparison with Petersen's communities. It is interesting first to notice that the characteristic species shown in bolder type in Table 1 are those of the Echinocardium-filiformis and Venus communities; and second, that nine of the total of twelve are included under Series A. A closer analysis shows that the remaining three species which are included under Series B are characteristic for Petersen's (v), although other (v) species occur under A. It is evident, therefore, that the proper significance of the two series requires to be determined before further comparisons with Petersen's communities can be made. If we compare the animals classified in Table 1 , we become aware of the somewhat striking way in which genera present different species in the two series, e.g. Nucula, Montacuta, Tellina, Spisula, Venus, Cardium, and Gari among the lamellibranchs. Petersen (5, page 17), in a discussion on the factors in the formation of communities, makes mention of a similar circumstance noted by him in earlier days on the cruises of the Hauch, and writes :-

". . . that closely related species, especially those of the same genus, are scarcely ever found living in one and the same area of a given water ; they may meet and fight out their war on a frontier line, but are never found to cover the same area of distribution altogether. Each has its own region, its own community. * The competition must be greatest between those species which are most closely related."

This appears to me to provide the key to the proper relationship existing between Series A and B. They are independent associations largely built up of species of genera which are common to both, and possess equal potentiality for expressing minor associations under certain circumstances. Each has its own characteristic species, including a Spatangid and a Venus. Series A is an Echinocardium cordatum-

\footnotetext{
* The italics are my own.-E. F.
} 
Venus gallina association, EeVg, and Series B a Spatangus purpureusVenus fasciata association, SpVf. They occur in similar depths of water, but differ in the type of bottom deposit in which they thrive. It will be observed that the symbols $\mathrm{EcVg}$ and SpVf have been used here for the first time. While it is admitted that the introduction of new terms makes the reading of papers of this kind more difficult to those unacquainted with previous work, yet such additions seems unavoidable. The following summary of the symbols used herein may therefore prove useful for reference :-

\section{SYMBOLS USED.}

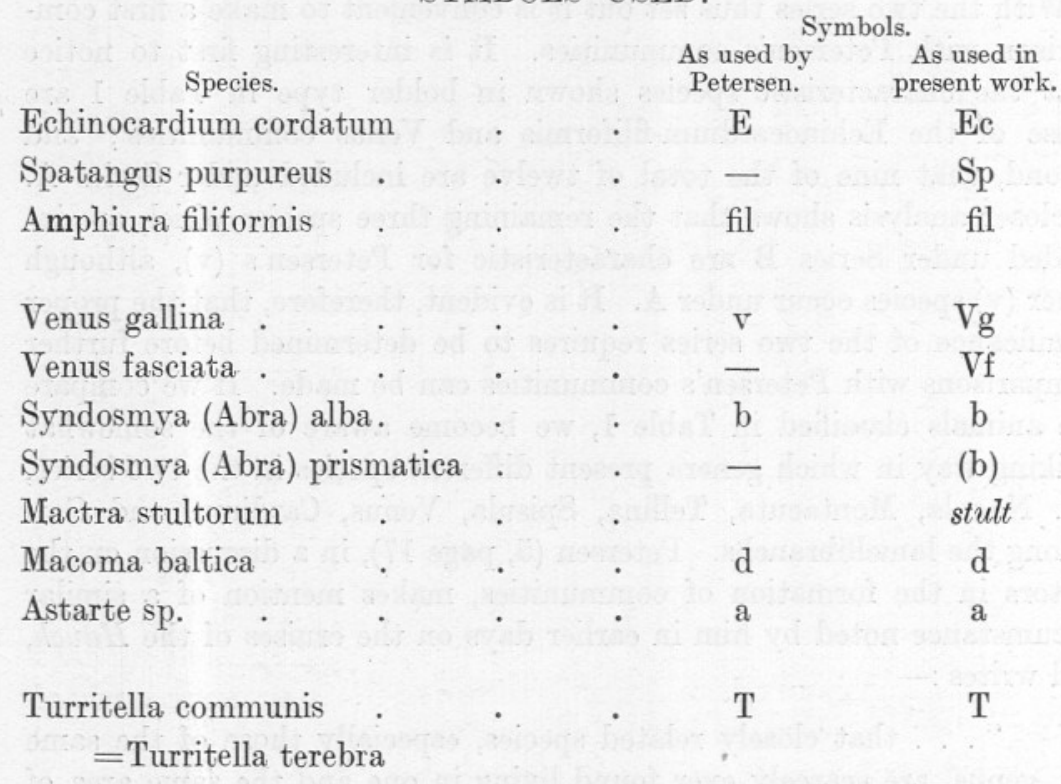

Returning now to the consideration of Petersen's (v) it becomes apparent that it is characterised by five species, of which two belong to an Echinocardium cordatum-Venus gallina association, and three to a Spatangus purpureus-Venus fasciata association. This, to my mind, necessitates the discarding of (v), on account of its composite structure, and the substitution of deeper water formations for each of the two Spatangid-Venus associations.

It has been shown above that the three species utilised by Petersen for characterising his E-fil. community are included under Series A. No ground has yet been located, however, where Amphiura filiformis and Turritella communis occur together characteristically, although fil. has been taken regularly and in numbers at Bigbury, and T. occurs in dense 


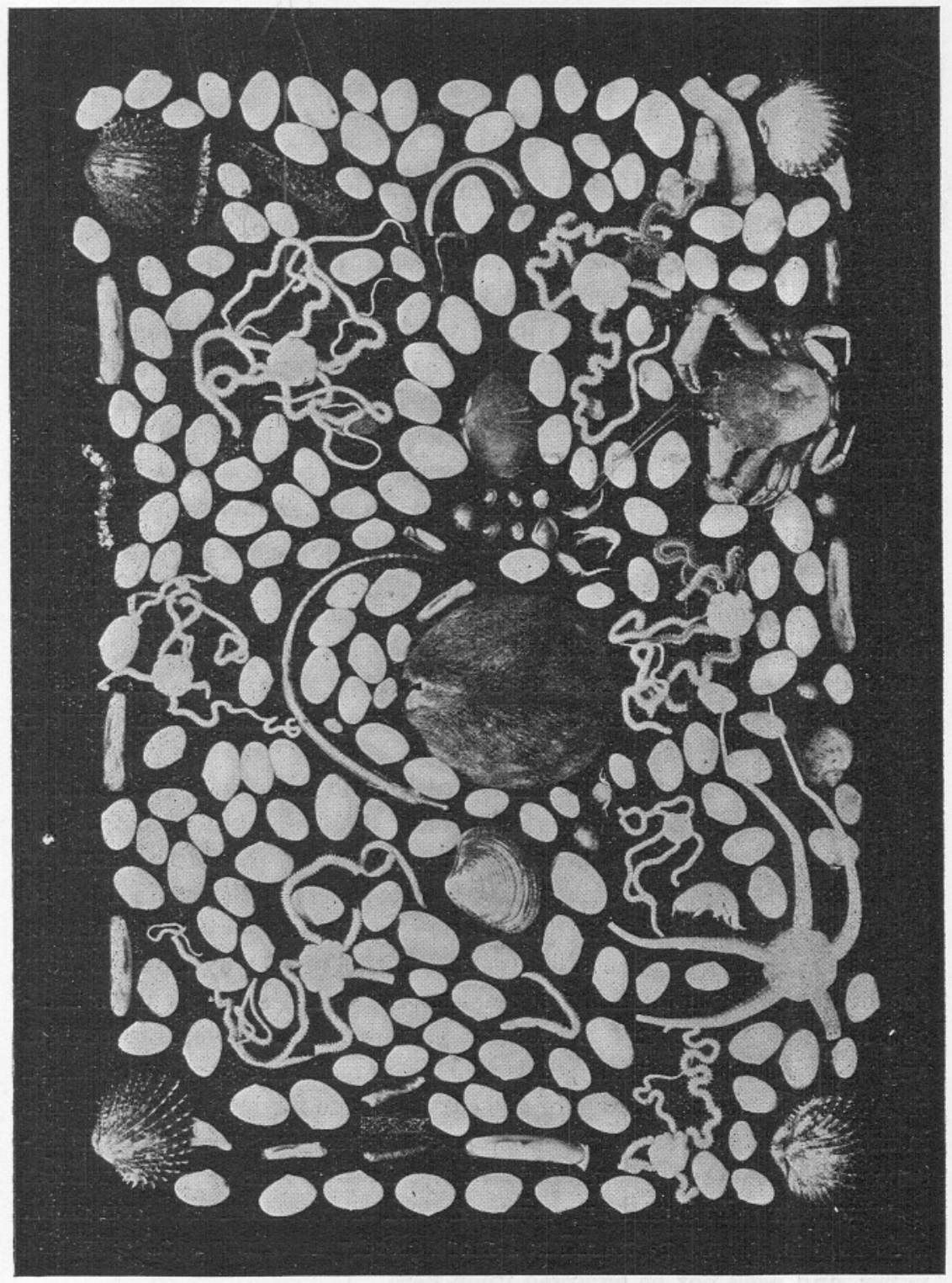

Fig. 1. EcVG COMMUNITY. $b+$ Ec. + fil.

Number of animals per $1 / 10$ sq. metre $\left(7 / 10^{7}\right.$ natural size).

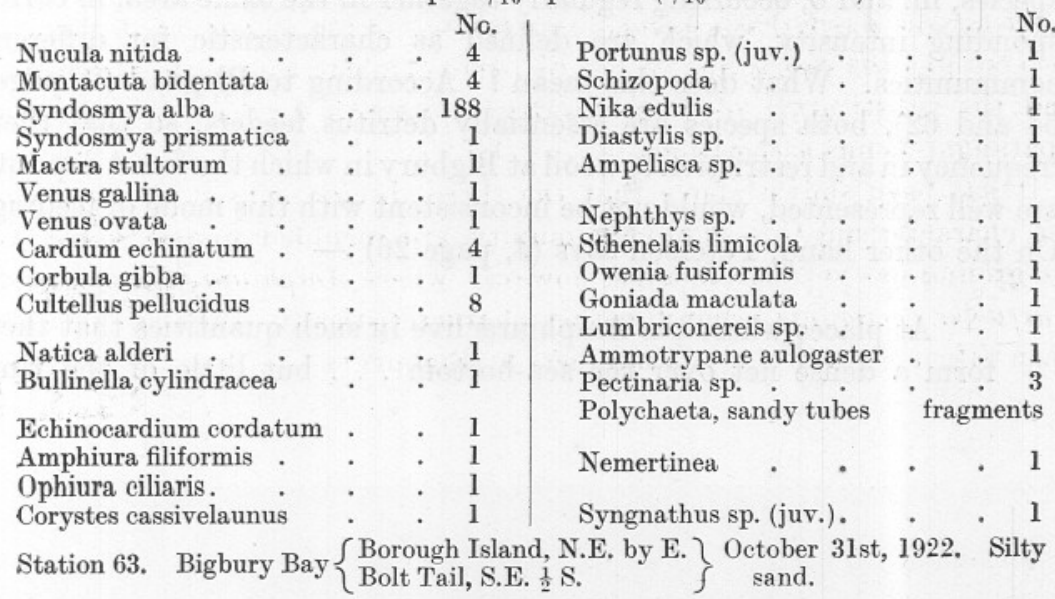


patches on the Rame-Eddystone grounds. It is to be noted that both of these localities lie in the heart of the Venus zone, whereas E. fil. is regarded by Petersen as the next deepest community to the Venus. Dealing with fil. first, it is a striking fact that the one ground on which it has been found in numbers is also inhabited by a dense population of many Series A animals, of which Syndosmya alba is the most frequent (see Fig. 1). This occurs in Bigbury Bay off Borough Island in a bottom soil of silty sand, one estimation of which showed 98 per cent of Grades VI, VII, and VIII, with Grade VIII claiming 18 per cent. The ground is limited in extent so that considerable differences in soil and numerical proportions of animals are obtained in successive hauls taken, say, at half-a-mile intervals. Frequent samples of from 1 to 10 dips of the sampler each have been taken from June 9th, 1922, onwards, and the results show a pronounced correlation between the numbers of fil. and those of the more important lamellibranchs present. How close this agreement is may be gathered from the accompanying graphic comparison between fil. and b (Fig. 2).

In the figure the actual numbers of individuals taken in the same sample at thirty-seven stations in Bigbury Bay from June, 1922, to the end of May, 1923, are recorded, irrespective of the number of hauls of the bottom-sampler at each station. The latter varies from 1 to 10 hauls per sample, so that the curves do not represent relative frequencies for either stations or time of the year, but this in no way detracts from the evidence of the striking agreement between the two curves indicated. Thus, whenever $\mathrm{b}$ is present in numbers, fil. is well represented, and when $b$ is at a minimum, fil. is also low in numbers. It may be added that the marked irregularity of the curves is due far more to differences in the percentage of silt in the bottom soil at the stations than to differences in the number of hauls per station; both species occur in greatest density where silt is most pronounced, and are absent from clean sand. This fact is, however, considered more closely in a late section of the paper, and need not be enlarged upon here.

We are, therefore, faced by the important fact that here are two species, fil. and b, occurring regularly together in the same area, in corresponding intensity, which are defined as characteristic for different communities. What does this mean? According to Blegvad (2, pages 54 and 62 ), both species are essentially detritus feeders, so that their frequency in and restriction to a soil at Bigbury in which the finest deposits are well represented, would not be inconsistent with this mode of feeding. On the other hand, Petersen says (4, page 26) :-

"At places where the Amphiuræ live in such quantities that they form a dense net over the sea-bottom . . . but little of the tiny 


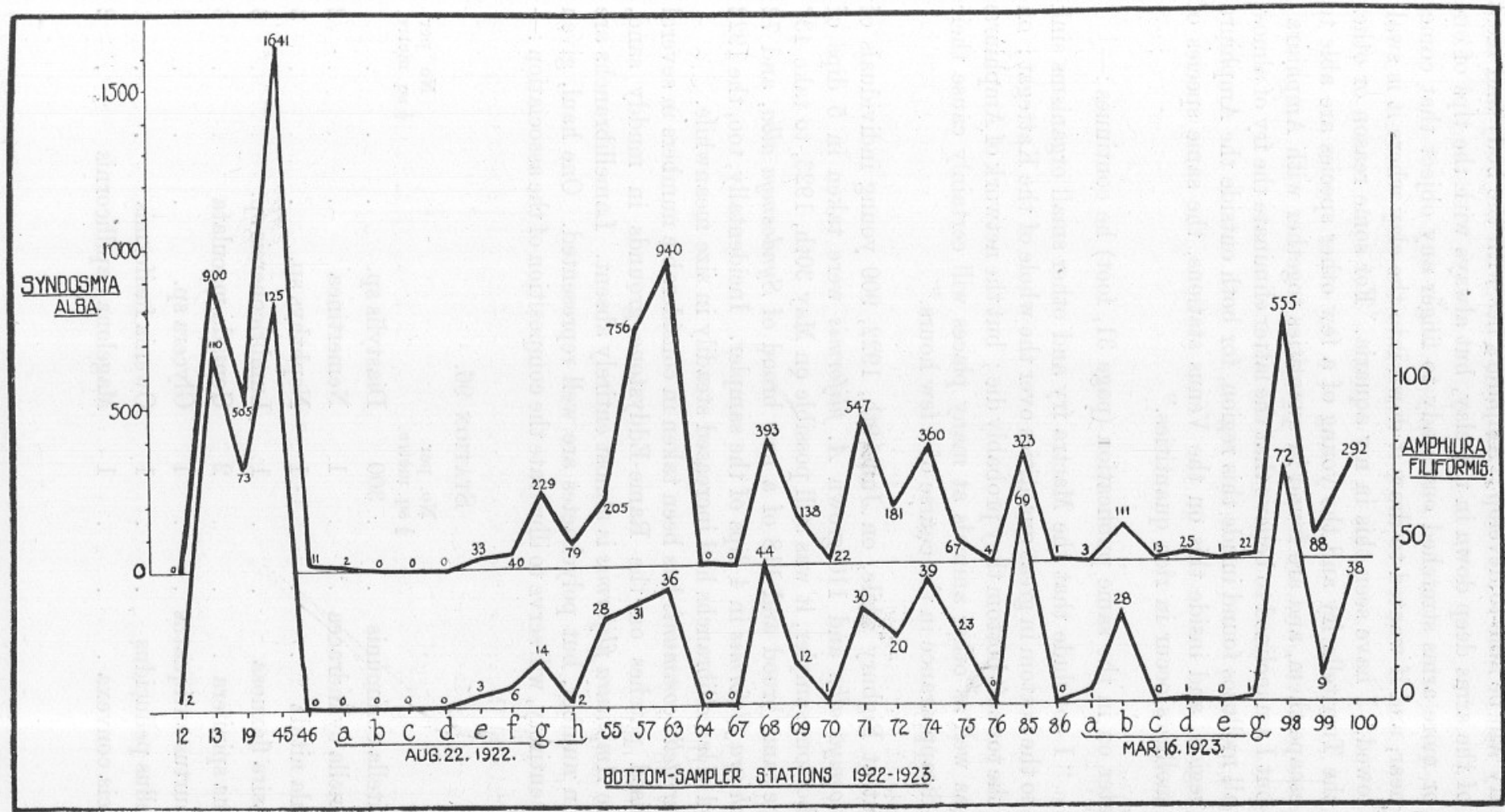

葛

Fig. 2.-Number of individuals of Syndosmya alba and Amphiura filiformis in the same sample of from 1 to 10 hauls of the $\frac{1}{10} \mathrm{~m}^{2}$ bottom sampler, at each of 37 stations in Bigbury Bay, from June 9th, 1922, to May 30th, 1923. 
fry will be able to develop; Amphiura lies with the body and most of the arms deep down in the clay, but always with the tips of one or more arms stretched out ready to finger any object that comes near, and if wanted to draw it down into the clay where it is swallowed. I have seen this in my aquaria. For some reason or other the Turritella fry and the young of a few other species are able to escape them, and are found in quantities together with Amphiura; but I am inclined to believe that the latter eliminate the fry of almost all molluses found inside this region, for both outside the Amphiura region, and inside this on the Venus stations, the same species of molluses occur in rich quantities."

Later on in the same publication (page 31, foot) he continues:-

"I conclude that the Mactra fry and other small organisms sink to the bottom in great quantities over the whole of the Kattegat; on the too soft bottom they probably die; but the network of Amphiuræ as well as other animals at many places will certainly cause their disappearance in the course of a few hours."

But at Bigbury while, on June 9th, 1922, 900 young individuals of Syndosmya alba and 110 grown $A$. filiformis were taken in 5 dips of the bottom-sampler, it was still possible on May 30th, 1923, to take 437 of the same brood and 118 of a new brood of Syndosmya alba, and 72 Amphiura filiformis in 4 dips of the sampler. Incidentally, too, the 1922 brood of lamellibranchs had increased steadily in size meanwhile.

Turritella communis has been taken in considerable numbers in several localised patches on the Rame-Eddystone grounds in muddy sand, where Amphiura filiformis is almost entirely absent. Lamellibranchs are few in number, but polychaetes are well represented. One haul, given in its entirety, will serve to illustrate the composition of the association :-

Station 96.

No. per

$\frac{1}{2}$ sq. metre.

Turritella communis . . $\quad .300$

Bullinella cylindracea

Nucula nitida

Thyasira flexuosa

Lucina spinifera .

Solecurtus antiquatus

Cultellus pellucidus

Thracia convexa

. 300

Diastylis sp.

Nemertinea

Nephthys sp.

Lumbriconereis sp.

Goniada maculata

Glycera sp.

Owenia fusiformis

Magelona papillicornis
No. per $\frac{1}{2}$ sq. metre. 
No. per

$\frac{1}{2}$ sq. metre.
No. per

$\frac{1}{2}$ sq. metre.

Cucumaria elongata . . 4 Notomastus latericeus . fragments

Cucumaria sp. . . . 1 Melinna adriatica . . 1

Amphiura filiformis . . 1 Ammotrypane aulogaster . 1

Gonoplax rhomboides . . 1 Aricia sp. . . . . 1

Alphæus ruber . . . 1 Cirratulidæ . . . 1

Ampelisca sp. . . . 7 Terebellidæ. $\quad$. $\quad . \quad 3$

In a later section of this paper, a subdivision of the EcVg community designated as $\mathrm{EcVg} m u d$ will be described, and without entering into the question of its composition, it may here be pointed out that this haul 96 includes its essential animals. Thus, as with A. filiformis, $T$. communis occurs in association with Venus animals (see Fig. 3). It is also of interest to note that large numbers of the shells of $T$. communis are frequently met with on the Rame-Eddystone grounds at Venus stations. In some cases, the shells are quite empty, but in others they may be occupied by either Anapagurus lcevis and Eupagurus sp. juv., or Phascolion strombi, and form the most important item in the fauna. Frequently, also, individuals of Sagartia sp. are to be found attached to the shells.

From the results of present work then, matters must rest in the position that although the two leading species of $\mathrm{E}$. fil. both occur in the Plymouth district, they are not in association, but appear to live separately in localised areas, which are not only surrounded by Venus formations, but are themselves populated by Venus animals.

Of the ten species selected by Petersen for characterising his Venus associations, we have already seen that seven are included under our Series A or EeVg association, and three under Series B or SpVf association :-

\begin{tabular}{|c|c|}
\hline Series $\mathrm{A}(\mathrm{EcVg})$ & Series B (SpVf) \\
\hline $\begin{array}{l}\text { Echinocardium cordatum. } \\
\text { Venus gallina. } \\
\text { Tellina fabula. } \\
\text { Spisula subtruncata. } \\
\text { Syndosmya alba. } \\
\text { Syndosmya prismatica. } \\
\text { Gari ferroensis. }\end{array}$ & $\begin{array}{l}\text { Spatangus purpureus. } \\
\text { Echinocardium flavescens. } \\
\text { Mactra elliptica. }\end{array}$ \\
\hline
\end{tabular}




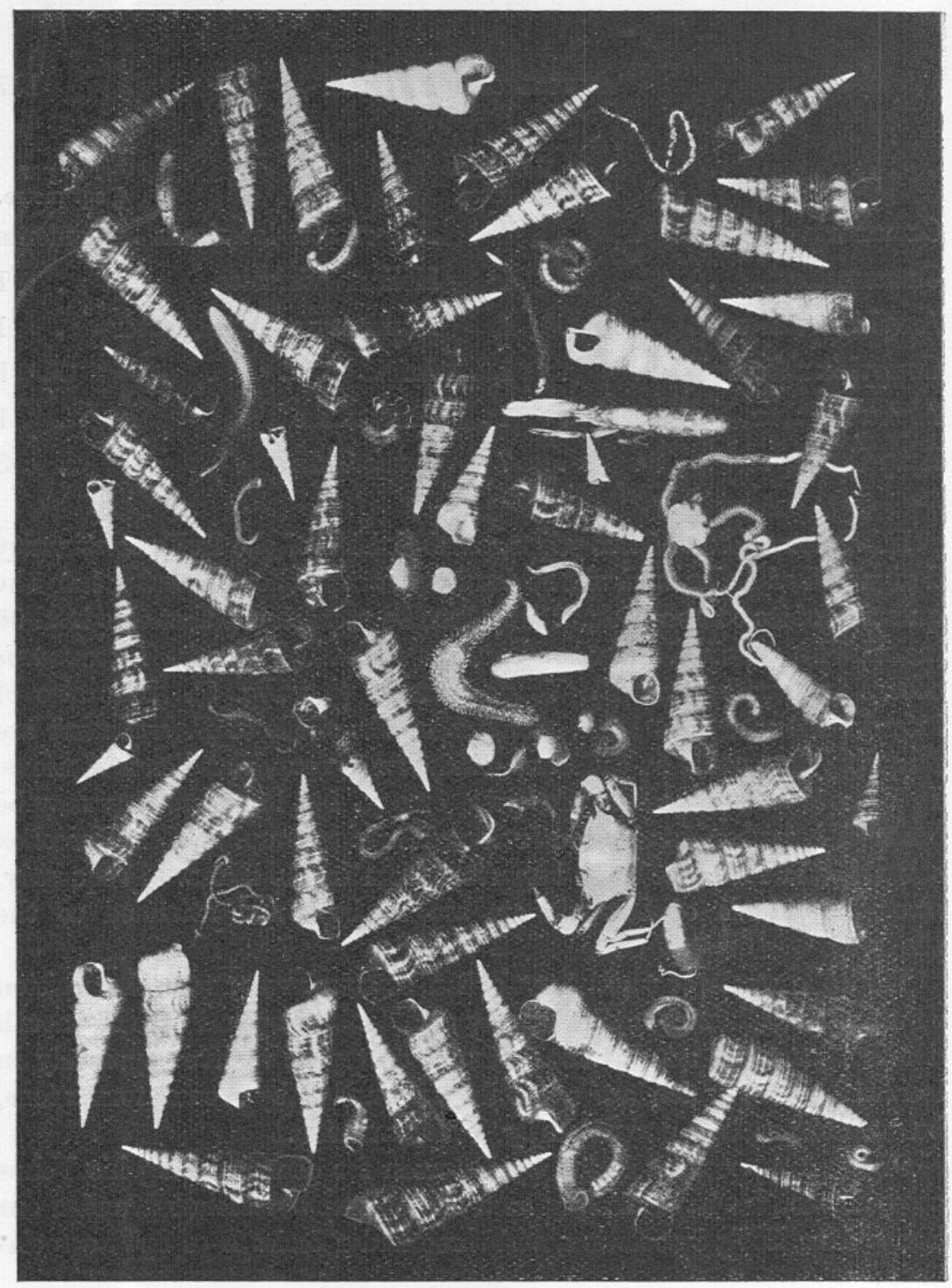

Fig. 3.

$\mathrm{VG}_{\mathrm{G}}+$ TURRITELLA COMMUNIS.

Number of animals per $1 / 10$ sq. metre $(6 / 10$ natural size).

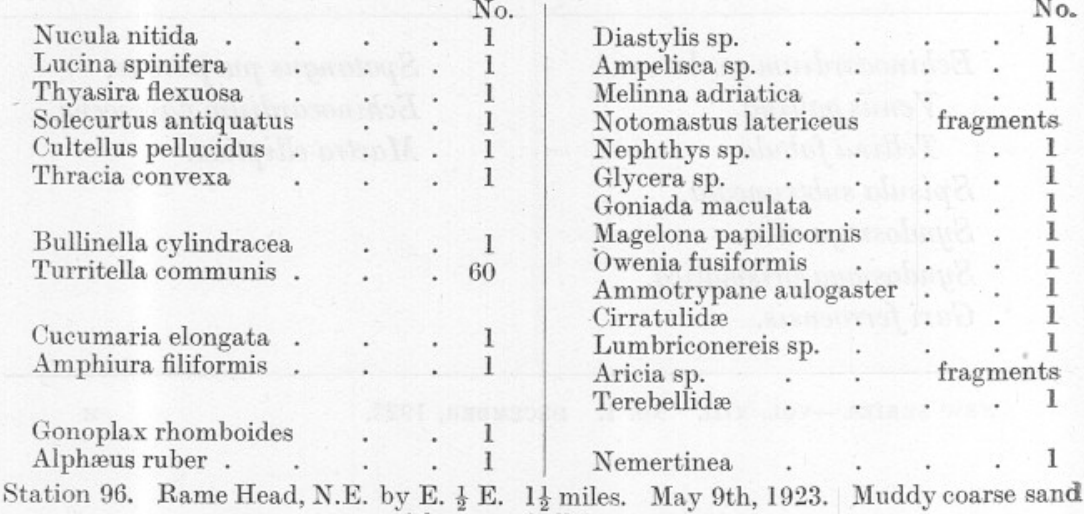
with some shell fragments. 
Of the seven species included under EcVg, Tellina fabula, Spisula subtruncata, and Gari ferroensis have not been taken in sufficient numbers to warrant their use as leading species; but the fact remains that when they are present, they occur under EcVg conditions. E. cordatum occurs quite generally on the sandy grounds outside the Breakwater from the shore outwards to the limits of the area, but not within Plymouth Sound. Venus gallina is likely to be met with both inside and outside the Breakwater on any of the EcVg stations, although it has never been taken in numbers comparable to those experienced in Danish waters. Its general distribution, however, is significant in the consideration of the Venus communities, for its presence in Series A and absence from B affords evidence of the distinction between the series. Syndosmya alba and $S$. prismatica are both well represented in outside waters, and the former also within the Sound, and there is a good indication that $S$. prismatica is more typical of deeper water, thereby confirming the reasonableness of its use by Petersen for the characterisation of a deeper Venus formation.

Owing to the varied nature of the bottom in Plymouth waters, and to the corresponding patchiness in fauna resulting from it, it will be realised that the fullest expression of $\mathrm{EcVg}$ will not be generally distributed. Examination of the results suggests, however, that silty sand is most favourable for the most typical expression of $\mathrm{EcVg}$, and that a change to either fine clean sand, or in the opposite direction to black mud, produces a more specialised association. Remembering the "depth" distinction between the two species of Syndosmya, also, we may therefore refer to four distinct sub-groupings of the EcVg series :-

Mactra stultorum

Venus gallina

Ensis ensis

(Meretrix chione)

(Donax vittatus)

(Lutraria elliptica juv.)
Sub-Groups of Series A (EcVg).
Sub-group 1.
Clean sand.

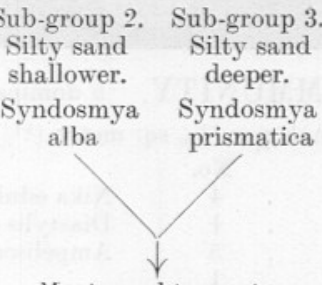

Mactra subtruncata Venus gallina Cultellus pellucidus Nucula nitida

Cardium echinatum

Montácuta bidentata
Sub-group 4.

(Syndosmya alba)

(Cultellus pellucidus)

(Thyasira flexuosa) Black mud. 


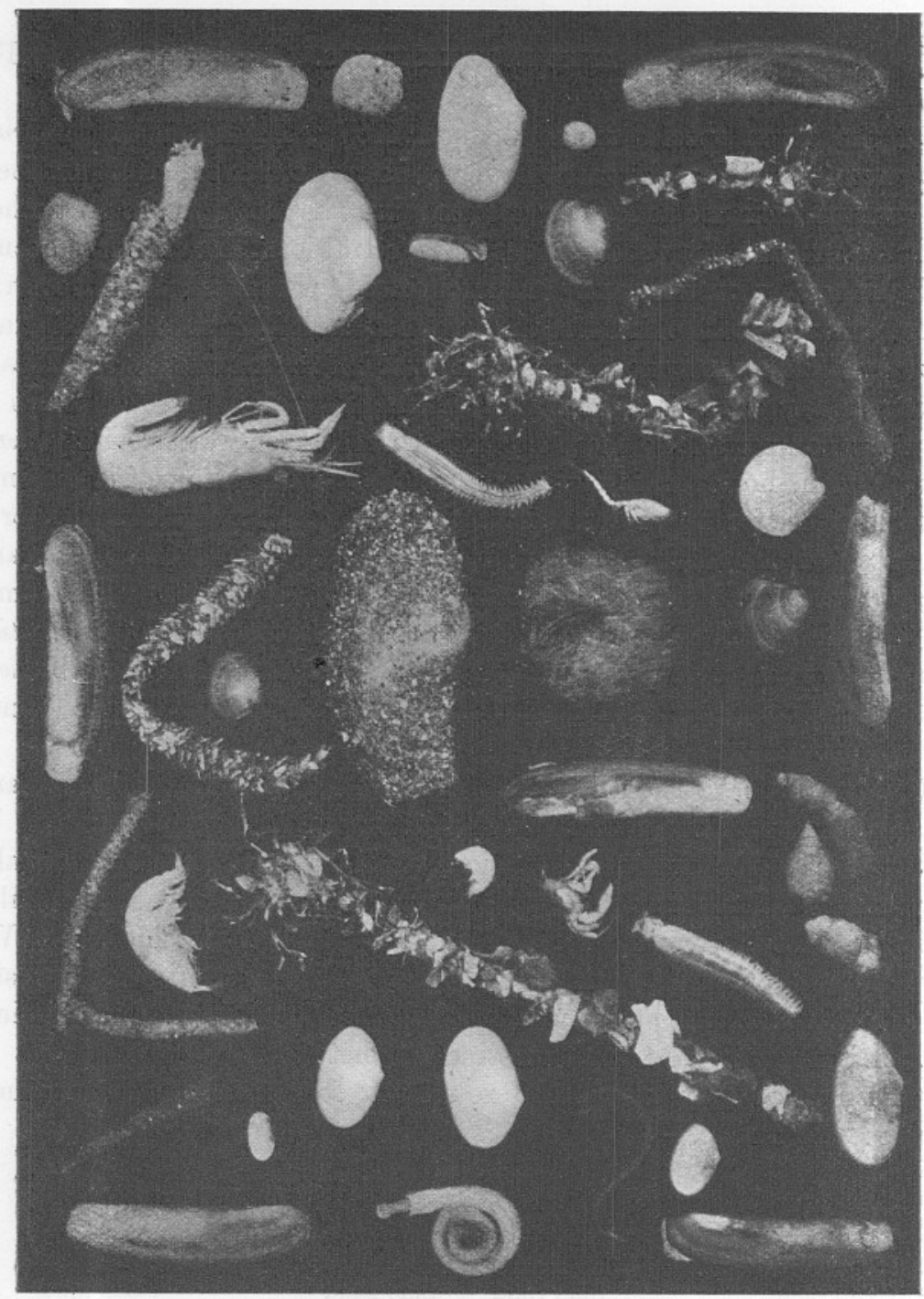

Fig. 4. EcVG COMMUNITY. b dominant over (b).

Number of animals per $1 / 10$ sq. meter $(11 / 10$ natural size).

Nucula nitida $\quad . \quad$. $\quad \begin{gathered}\text { No. } \\ 4\end{gathered} \mid$ Nika edulis . . No.

Tellimya ferruginosa $\quad \cdot \quad \cdot \quad 1 \quad$ Diastylis sp. $\quad \cdot \quad \cdot \quad \cdot \quad \cdot \quad \cdot \quad 1$

Syndosmya alba $\quad . \quad 5 \quad 5 \quad$ Ampelisca sp. $\quad . \quad . \quad . \quad . \quad 1$

Syndosmya prismatica $\cdot \quad \cdot 110$

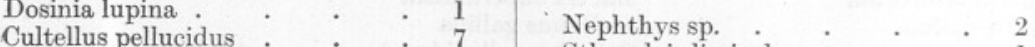

Lyonsia norvegica . $\quad . \quad$ Sthenelais limicola $\quad . \quad$. 1

Owenia fusiformis . 1

Goniada maculata $\quad \cdot \quad \cdot \quad \cdot \quad 1$

Pectinaria sp. $\quad . \quad$. 1

Lanice conchilega, tubes irequent

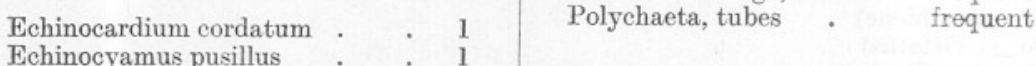

Anapagurus levis . $\quad . \quad$. 1 Nemertinea . . . 1

Station 104. Borough Island E., Revelstoke Point N.E. by N. June 12th, 1923. Silty sand with some flaky shell fragments. 
Stb-Groups of Series A (EeVg)-continued.

Sub-group 1. Clean sand.

Bathyporeia sp. Iphinoe trispinosa

Echinocardium cordatum

Nephthys sp. Owenia fusiformis

Polychæta with sandy tubes

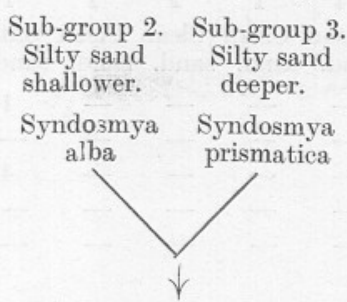

Diastylis sp.

Diastylis sp.

Gonoplax rhomboides

Alphæus ruber

Callianassa

subterranea juv.)

E. cordatum

Cucumaria elongata

Melinna adriatica

Notomastus latericeus

Nephthys sp.

Owenia fusiformis

Pectinaria sp.

Goniada maculata

Glycera sp.

Sthenelais limicola

Cirratulidæ

Nephthys sp.

Goniada maculata

Glycera sp.

Sthenelais sp.

The importance of the nature of the bottom deposits in determining the fauna is thoroughly well illustrated by the results of a series of hauls taken in Bigbury Bay, passing from the clean sand inshore across the silty b fil. patch to relatively clean shell gravel. On August 22nd, 1922, nine separate single dips of the sampler were taken at short distances apart (see Chart facing page 167) and the numbers of certain species are given below which show quite distinctly the passage from animals of Sub-group 1 (above) to those of Sub-group 2 :-

August 22nd, 1922.

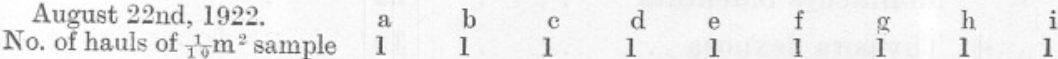

Nature of soil.

Clean Clean Clean Clean Silty Silty Silty Silty Shelly

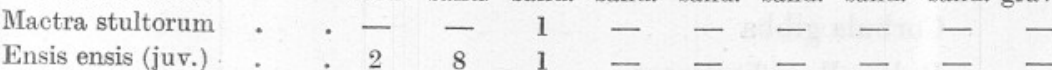

sand. sand. sand. sand. sand. sand. sand. sand, gravel.

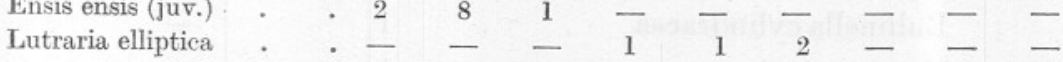

Syndosmya prismatica $\quad-\begin{array}{llll}2 & 1 & - & 2\end{array}-$

Syndosmya alba $\quad . \quad \begin{array}{llllllllll} & 2 & - & - & - & 33 & 40 & 229 & 79 & -\end{array}$

$\begin{array}{llllllllll}\text { Cultellus pellucidus . } & 1 & 3 & - & 2 & 5 & 6 & 23 & 18 & -\end{array}$

Cardium echinatum . $\quad-\quad-\quad-\quad \begin{array}{llllrrr} & 1 & 1 & 2 & 1 & 4 & 3\end{array}$

Venus gallina. $\cdot$ - $-1-1--$

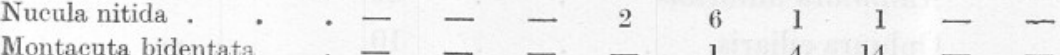




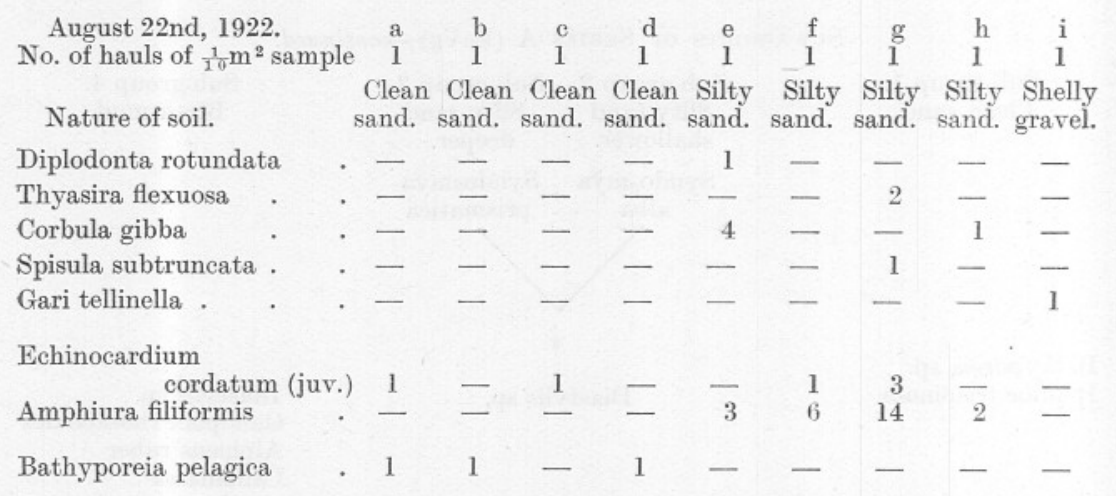

As a second illustration, two hauls of the sampler taken on the same day, February 14th, 1923, at stations separated slightly over one mile may be compared :-

\begin{tabular}{lcc|c} 
& No. of Dips of Sampler & Station 85 & Station 86 \\
[Allen's & Nature of Soil. & 5 & 5 \\
grades] & Grades VI, VII and VIII & $98.0 \%$ & $99 \cdot 0 \%$ \\
Grade VIII & $18 \%$ & $0 \cdot 2 \%$
\end{tabular}

Mollusca.

Mactra stultorum . . . . $\quad$ - $\quad 2$

Ensis ensis (juv.) .

Syndosmya alba $\quad . \quad . \quad . \quad 323 \quad 1$

Syndosmya prismatica . . $\quad 3 \quad 1$

Spisula subtruncata $\quad$. 110

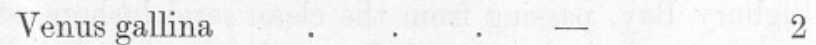

Venus ovata . . . . . $\quad$ - $\quad 1$

Cultellus pellucidus . . $\quad 24$ -

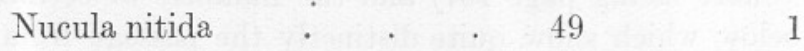

Cardium echinatum . . 10 -

Montacuta bidentata . . 22 -

Thyasira flexuosa . . . 10 -

Diplodonta rotundata . . 11

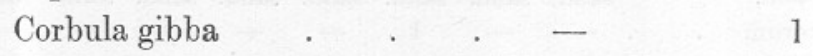

Bullinella cylindracea $\quad . \quad$. 11 -

Nassa reticulata . . . $\quad 1 \quad$ -

ECHINODERMa.

Echinocardium cordatum - 1 -

Amphiura filiformis . . $69 \quad-$

Ophiura ciliaris . . . 10 - 
No. of Dips of Sampler

Station 85

5

Nature of Soil.

Grades VI, VII and VII Grade VII.
$38 \cdot 0^{a} / \mathrm{c}$
$18 \%$
Statiox 86

5

$99 \cdot 0 a_{c}$ $0 \cdot 2^{a}$ c

Crustacea.

Decapoda . . . . 1

Monoculodes carinatus . . 2

Bathyporeia sp. . . . -

Diastylis . . . . 3

Iphinoe trispinosa .

1
2
-
3

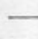

1

3

1

4

Polycheta.

Nephthys sp. $\quad$. $\quad$. 2

6

Owenia fusiformis . . . 12

Pectinaria sp.

Goniada maculata

Sthenelais limicola

Phyllodocidæ

Polynoidæ

Lumbriconereis sp.

Sandy tubes

12

sev.

Sub-group 1, typical of clean sand, shows a marked reduction in the number of commonly occurring lamellibranchs; but those which persist are distinctive, Mactra stultorum being probably the one most generally met with. Venus gallina here assumes relative importance, although possibly more on account of the scarcity of other species than on its own increased intensity. Ensis 'ensis frequently occurs in place of Cultellus pellucidus, which is so frequent in Sub-groups 2 and 3. Two species of Bathyporeia and the Cumacean Iphinoe trispinosa have only as yet been taken regularly and in numbers in clean sand, and would therefore appear to be of use in defining the sub-group. Among the polychaetes, individuals of Nephthys sp. are always taken in numbers, and sandy-tube dwellers are prevalent.

In Sub-group 4, typical of black mud (see Fig. 5), the reduction in lamellibranchs is still more apparent, while Echinocardium cordatum is for all practical purposes absent. Polychaetes are very abundant, however, and the most obvious feature of the hauls is the presence of large numbers of the ampharetid Melinna adriatica and its muddy tubes. The capitellid Notomastus latericeus is also common, and Cirratulids, Glycera, Goniada, Nephthys, Scalibregma, Magelona, and Lumbriconereis are well repre- 


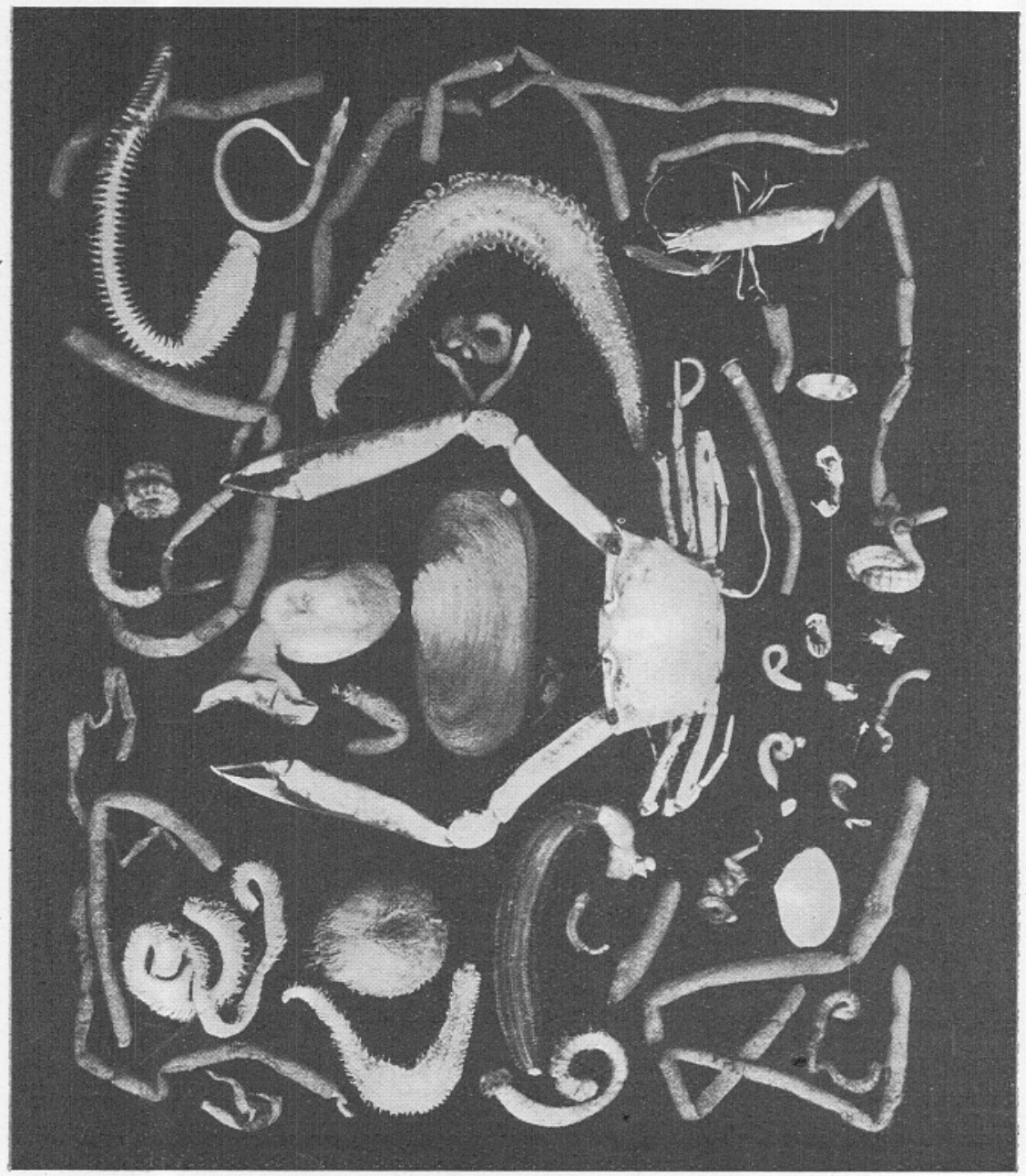

Fig. 5.

EcVG COMMUNITY. EcVG MUD.

Number of animals per ${ }^{1} / 10 \mathrm{sq}$. metre $(8 / 10$ natural size).

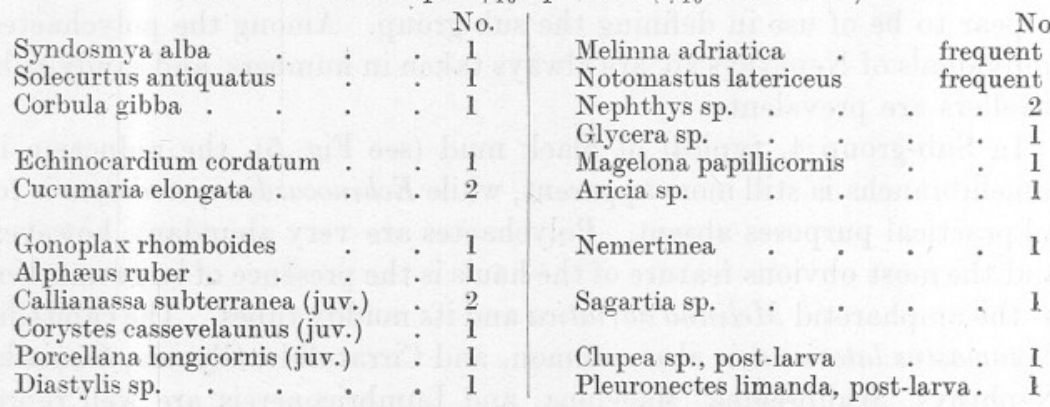

Station 5. Rame Head E. $\frac{1}{4}$ N. 13 miles. May 31st, 1922. Black mud. 
sented. The chief echinoderm is Cucumaria elongata, which is of regular occurrence, while Leptosynapta and Labidoplax are not uncommon. The three decapods, Gonoplax rhomboides, Alphaus ruber, and Callianassa subterranea, are generally taken, thereby adding to the distinctive character of this sub-group. This mud formation is obviously different from the others, although it is still composed of $\mathrm{EcVg}$ animals. It provides an example of a eommunity expression in which the defined characteristic species of the main community are not typically represented, and demonstrates the need for a full description of the general composition of all defined animal communities, in order that such specialised expressions may be recognised.

The naming of these four sub-groups requires some consideration.* The more typical, Nos. 2 and 3 , are to be regarded merely as depth formations of the full EcVg expression. It is to be anticipated that at intermediate depths, Syndosmya alba and S. prismatica may occur in equal and not necessarily large numbers, when the formation may be termed $\mathrm{Vg}+\mathrm{Ec}$ as the equivalent of Petersen's $\mathrm{v}+\mathrm{E}$. In shallower or sheltered waters, when Sub-group 2 is exhibited, the formation may rightly be termed $b+E c$; while in deeper waters (b) seems an appropriate abbreviation, for it indicates the importance of Syndosmya (Abra) prismatica (b), but at the same time avoids any possible confusion with the composite (v) of Petersen. Sub-group 1 merits a distinctive term, for it is a recognisable formation both in Bigbury Bay and Whitsand Bay, and Vg stult. +Ec may be utilised, although it is clearly a reduced form of $\mathrm{Vg}+\mathrm{Ec}$. The naming of Sub-group 4 raises a peculiar difficulty, for Echinocardium and lamellibranchs generally are not sufficiently regular in occurrence to be used for characterisation. EcVg mud may, however, suffice for distinctive abbreviation.

With regard to the SpVf series (see Fig. 6) it must be admitted that no definite sub-community groupings equivalent to those of EcVg have as yet been attempted. The grounds are much more localised, and differ considerably in the number of species which they contain. The distribution of the typical community species is evidently influenced by the degree of coarseness of gravel, the relative amount of shell fragments, and the amount of silt. For instance, Amphioxus and Polygordius may be associated in being restricted to a clean soil almost entirely made up of broken shell fragments of medium and fine grades, whereas Venus fasciata is not so restricted. The important fact remains that the fullest community expression of SpVf occurs only where the soil is relatively clean, and consists of gravels with a big proportion of shell, whereas that of $\mathrm{EcVg}$ is restricted to deposits of silty sand.

* The composition of Petersen's communities is shown on page 165 of this paper; and on page 172 a summary of abbreviations used herein will be found. 


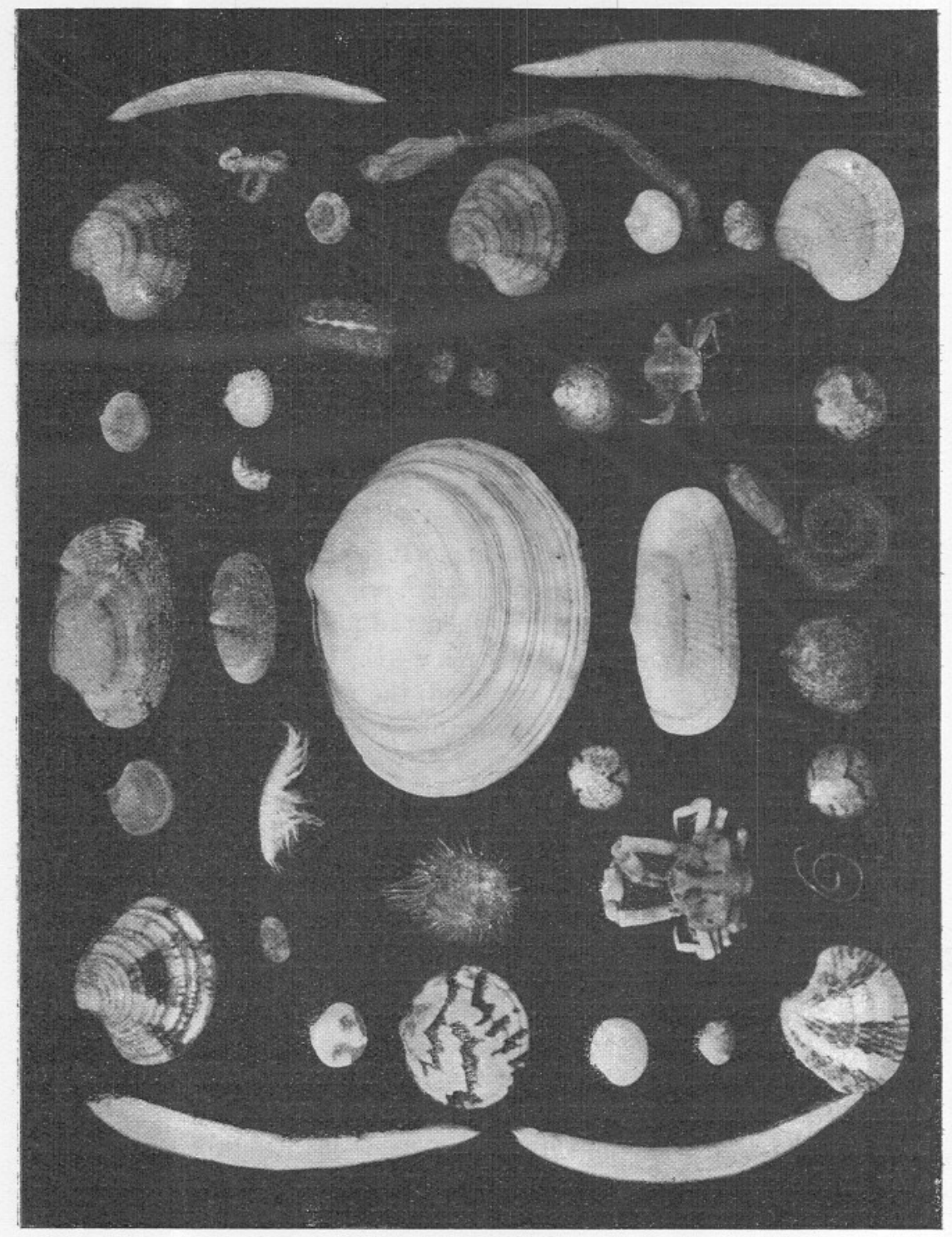

FIG. 6.

\section{SPVF COMMUNITY.}

Number of animals per $1 / 10$ sq. metre $(11 / 10$ natural size).

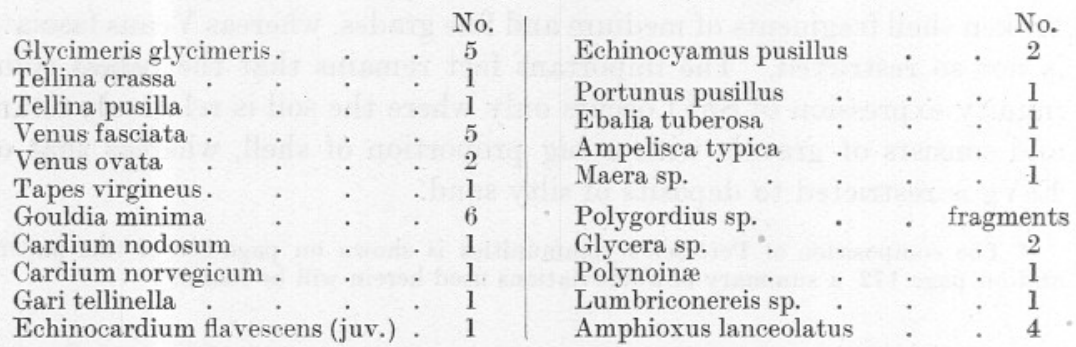

Station 81. Eddystone S.S.E. $\frac{1}{2}$ E. $\frac{1}{2}$ mile. January 25th, 1923. Clean shell gravel. 
Owing, again, to the general irregularity in bottom deposits over the area, a large part of the whole must be regarded as unsuitable for the full expression of either $\mathrm{EcVg}$ or SpVf. In some cases the conditions will permit of some of the species from both communities living together, and "mixed" hauls will be the result. It is also possible that on the rough and stony grounds, where good sampling with the bottom-sampler is practically impossible, there may be another series of animals. In this connection it is worth noting that on two occasions only Nucula nucleus has been taken in fair numbers (Stations 6 and 106), and both from deposits of muddy coarse materials. In haul 6, Astarte sulcata also occurred-the solitary record of this species.

In Plymouth Sound both EcVg and SpVf are well represented, although, as already stated, without their leading Spatangids. SpVf occurs in its most typical form on Queen's Ground, with a dense growth of young Spisula elliptica outnumbering everything else during the summer of 1922. The association (with the exception of the Spisula growth) bears a close resemblance to that of the Eddystone shell-gravel (cf. Stations 23 , 35, etc., with Stations 20 and 81 , etc.), with certain exceptions of the relative frequency of a few species in the two localities. On July 24th, 1922, a dense growth of young Mytilus edulis was located on the shallower more inshore part of this ground. This provides an interesting instance of the invasion, possibly only temporarily, of a Venus community by an Epifaunal species of the inshore Macoma community.

$\mathrm{SpVf}$ is also represented on two other grounds, though in reduced form-off Bovisand Pier, where Mactra elliptica (juv.) also occurred in numbers in 1922; and off Melampus Buoy, but here, to some extent, mixed with a sandy EcVg fauna.

The bottom of the greater part of the Sound is covered with either black mud, or sand, or a mixture of the two in varying proportions, and it is populated essentially by $\mathrm{EcVg}$ animals. The sub-community associations $\mathrm{b}$ and $\mathrm{EcVg}$ mud are undoubtedly the most pronounced, the hauls of the bottom-sampler showing varying degrees of mixing corresponding to the changes in proportion of mud to sand. In Jennycliff Bay, where the deposits are almost wholly black mud, Melinna and other polychaetes occur in abundance, and Syndosmya alba is well represented. There is in addition a rich growth of Thyasira flexuosa. As one leaves the mud and enters muddy sand, such as may occur in moving to the neighbourhood of the anchorage buoys, b becomes more pronounced, until, in sandy mud, it is dominant over the $\mathrm{EcVg}$ mud species, and the fauna may be compared quite fairly with that of the outside $b+$ Ec stations, with, of course, the exception of Ec.

Two other mud grounds are worthy of mention. In the enclosed Millbay Docks, in addition to the typical mud forms, tiny cirratulids 
(Heterocirrus (?) sp.) were in enormous abundance on the occasion of a sampling on July 10th, 1922. Between Batten Breakwater and the Mallard Buoy, Tapes pullastra and Mya truncata occur. These two species are reminiscent of Petersen's Macoma community d, although the station is mainly EcVg. Other d animals, e.g. Arenicola marina, Mytilus edulis live on the shores, and the characteristic species Macoma baltica has been recorded from the river off Saltash, which is sufficient evidence of the presence of this complex community in the district.

Petersen's prediction for the Plymouth area may now be reviewed in light of the foregoing account. Without doubt, the grounds are populated chiefly by Venus communities with Spatangidæ, but by TwO VENUS COMMUNITIEs, each with a characteristic Venus and a characteristic spatangid, and of equal potentiality for expressing subassociations. Several of the sub-communities of Petersen's v are recognisable in the district, but (v) cannot be accepted as it is made up of species of both main communities. There is, however, a distinct deeper sub-association of one of the communities which is comparable to (v), and it is suggested that there may also be a deeper sub-association of the other. The characteristic species of Petersen's E. fil. are both represented, but never associated, and they are found separately with Venus animals.

The composition of the two Plymouth Venus communities may be set out as under :-

\section{VENUS COMMUNITIES WITH SPATANGIDE.}

A. In bottom deposits of fine grades.-Echinocardium cordatumVenus gallina community EcVg.*

A1. In clean sand . . Vg stult \pm Ec.

A2. In silty sand . $\mathrm{Vg} \pm \mathrm{Ec}$.

A2a. In shallower and sheltered waters $\mathrm{b} \pm \mathrm{Ec}$.

A2 $\beta$. In deeper waters . . . (b).

A3. In black mud . . EcVg mud.

B. In bottom deposits of shelly gravel.-Spatangus purpureus-Venus fasciata community SpVf.

N.B.-Fil. and T. may occur separately with sub-associations of A.

In the photographs which accompany the text the number of animals per one haul of the $\frac{1}{10}$ sq. metre bottom-sampler, calculated from the results of the hauls at certain stations, is shown. In the case of many species the actual density is considerably less than 1 per $\frac{1}{10}$ sq. metre,

* See footnote to page 185 . 
but one individual has been included in the photograph to indicate that the species may occur. It should also be noted that in the preparation of the photographs no attempt has been made to represent the actual size of the piece of ground ( $\frac{1}{10}$ sq. metre), and the animals have been arranged to exhibit clearly the general composition of the particular community formation.

During the summer of the year 1921, Mr. J. R. Baker carried out quantitative estimations of the animals found in samples of black mud, fine sand, and shell gravel, taken from certain grounds in the Plymouth district. His samples were collected with an ordinary conical dredge provided with a canvas bag, and either ten, twenty, or thirty litres of bottom deposit, according to the amount brought up, were passed through sieves similar in mesh to those utilised by Petersen. His results, when tabulated on a uniform basic sample of twenty litres, are interesting for comparison with those obtained with Petersen's bottom-sampler and recorded above, with regard both to the community formations and the working efficiency of the two collecting instruments. In Table 2 (page 190) I have arranged a number of selected species in a manner conveniently to show at a glance their frequency of occurrence in the three types of deposit.

It is to be noticed that my SpVf species are confined to the shell gravel, and my EcVg species shared, by the fine sand and mud, with Venus fasciata and Venus gallina regularly occurring. In the fine sand $\mathrm{EcVg}$ stult. species are well represented (although Mactra stultorum itself does not appear). This is to be expected, for three of the five samples were taken from Whitsand Bay and Bigbury Bay. The two remaining samples were collected from the offshore Eddystone Grounds, and include Syndosmya prismatica, and thus afford confirmation for the existence of my (b) :-

Fine Sand Samples.

$\begin{array}{ccc}\text { Whitsaxd } & \text { BIGBURY } & \text { EDdystone W. } \\ \text { Bay. } & \text { Bay. } & \text { ea } 6 \text { miles. } \\ \text { So. of samples } & \text { No. of samples } & \text { No. of samples } \\ \text { in which present } & \text { in which present } & \text { in which present }\end{array}$

$\begin{array}{lcrrrr}\text { Donax vittatus } & \cdot & \cdot & 1 & - & - \\ \text { Meretrix chione } & \cdot & \cdot & 1 & - & - \\ \text { Ensis ensis. } & \cdot & \cdot & 1 & 1 & - \\ \text { Venus gallina } & \cdot & \cdot & 2 & 1 & 1 \\ \text { Cultellus pellucidus } & \cdot & \cdot & - & 1 & 2 \\ \text { Syndosmya prismatica } & \cdot & - & - & 1 \\ \text { Echinocardium cordatum } & \cdot & 1 & 1 & 1 \\ \text { Iphinoe trispinosa } & \cdot & \cdot & 2 & 1 & - \\ \text { Bathyporeia sp. } & . & \cdot & 1 & - & -\end{array}$




\section{TABLE 2.}

Mr. Baker's Conical Dredge Samples. (Summer, 1921.) Plymouth.

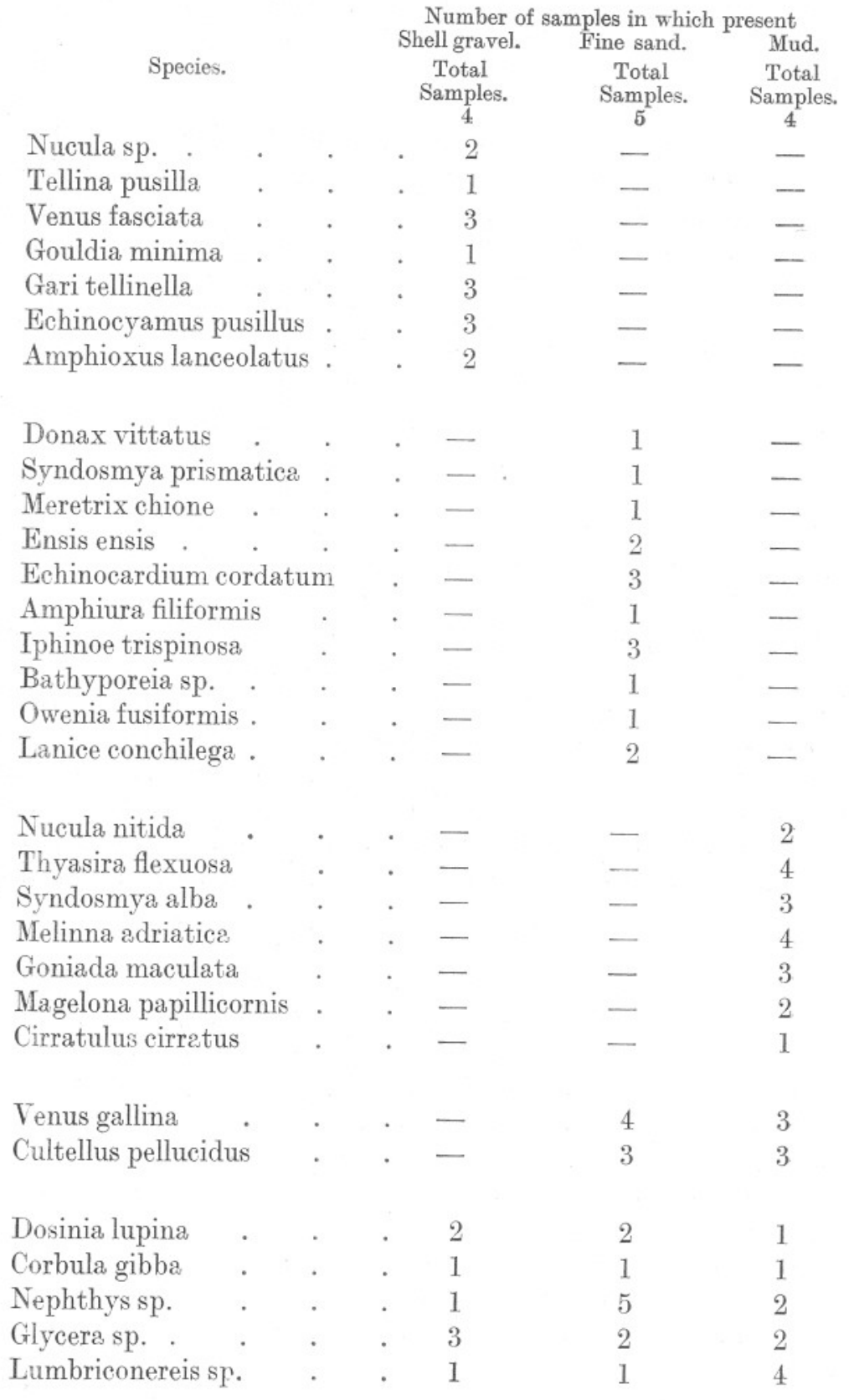


The samples of black mud were obtained exclusively from Plymouth Sound, and compare most favourably with the bottom-sampler hauls in the same localities, the leading EcVg mud polychaetes and Thyasira flexuosa being well represented :-

\begin{tabular}{|c|c|c|c|c|}
\hline Species. & $\begin{array}{l}\text { OFF MALLARD } \\
\text { BuoY. } \\
\text { No. of samples } \\
\text { in which } \\
\text { present }\end{array}$ & $\begin{array}{c}\text { RUM } \\
\mathrm{B}_{\mathrm{AY}} \\
\begin{array}{c}\text { No. of samples } \\
\text { in which } \\
\text { present }\end{array}\end{array}$ & $\begin{array}{l}\text { JENNYCLIFFE } \\
\text { BAY. } \\
\text { No. of samples } \\
\text { in which } \\
\text { present }\end{array}$ & $\begin{array}{l}\text { Average No. of } \\
\text { specimens per } \\
1 \text { sample of } \\
20 \text { litres. }\end{array}$ \\
\hline Thyasira flexuosa & 2 & 1 & 1 & 9 \\
\hline Syndosmya alba & 1 & 1 & 1 & 5 \\
\hline Venus gallina & 2 & 1 & 一 & 4 \\
\hline Cultellus pellucidus & 2 & 1 & - & 3 \\
\hline Melinna adriatica & 2 & 1 & 1 & 114 \\
\hline Goniada maculata & 1 & 1 & 1 & 11 \\
\hline Lumbriconereis sp. & 2 & 1 & 1 & 14 \\
\hline Magelona papillicorni & iis . & 1 & - & 2 \\
\hline
\end{tabular}

It is a little difficult to know how to compare the working efficiency of the conical dredge as used by Mr. Baker with that of the bottomsampler, for the instruments work on fundamentally different principles. It cannot be denied, however, after the examination of the results of the comparatively few hauls made during the summer of 1921 (see Valuation Lists, p. 221), that the conical dredge was able not only to capture the majority of the more important community species on the grounds investigated, but also to indicate in some degree the relative frequency of certain forms. The great disadvantage of the necessity for towing, whereby exactness in determination of position and of area covered is most seriously reduced, can never be overlooked, especially when working in localities where slight changes in position are of vital importance; but in spite of this, it is evident that much good work may be accomplished with this instrument. It may be of interest to include here the results of an experiment conducted at Bigbury Bay on May 30th, 1923, when one haul of the conical dredge of about two minutes' duration was taken as nearly as possible in the same place as four dips of the bottom-sampler. The ground chosen was inhabited by a flourishing growth of b fil., with a good variety in animal life in a soft silty soil at a depth of 15 fathoms. The amount of deposit brought up by the dredge had a volume of two and half times that of the four bottom-sampler hauls put together, or, in other words, one dredge haul was equal in 
volume to ten of the bottom samples. The numbers of the various animals captured were as follows :-

\section{Conical Dredge.}

BOTTOM SAMPLER.

No. per $2 / 5$ haul.

Nucula nitida . $\quad$. $\quad 91$ (calculated). No. per 4 dips.

Thyasira flexuosa . . 14

$36 \cdot 4$

Montacuta bidentata. . 35

$5 \cdot 6$

Syndosmya alba . . . 1130

Mactra stultorum

452

555

Cardium echinatum . . 42

Cultellus pellucidus . $\quad$. $\quad 29$

Garicostulata . . . 6

Tellimya ferruginosa . . - -

Syndosmya prismatica . 5

Spisula subtruncata . . . 1

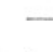

2

Venus gallina . . . . 5

Venus ovata $\quad . \quad$. 3

Dosinia lupina . . . . 5

Corbula gibba . . . 2

Bullinella cylindraces . . 8

Buccinum undatum . . 1

Actæon tornatilis . . -

Nassa reticulata . . . . -

Echinocardium cordatum . 2

Amphiura filiformis . $\quad 144$

Ophiura ciliaris . . . 12

Ophiothrix fragilis . . -

Cucumaria sp. . . .

Decapoda larvæ . $\quad$. 3

Amphipoda . . . 10

Diastylis sp. $\quad . \quad$. $\quad . \quad 10$

Iphinoe trispinosa $\quad$. $\quad$. 1

Caprellidæ . . . . . 1

Pycnogonida . . . . 1 
Conical Dredge.

BotToM SAMPLER.

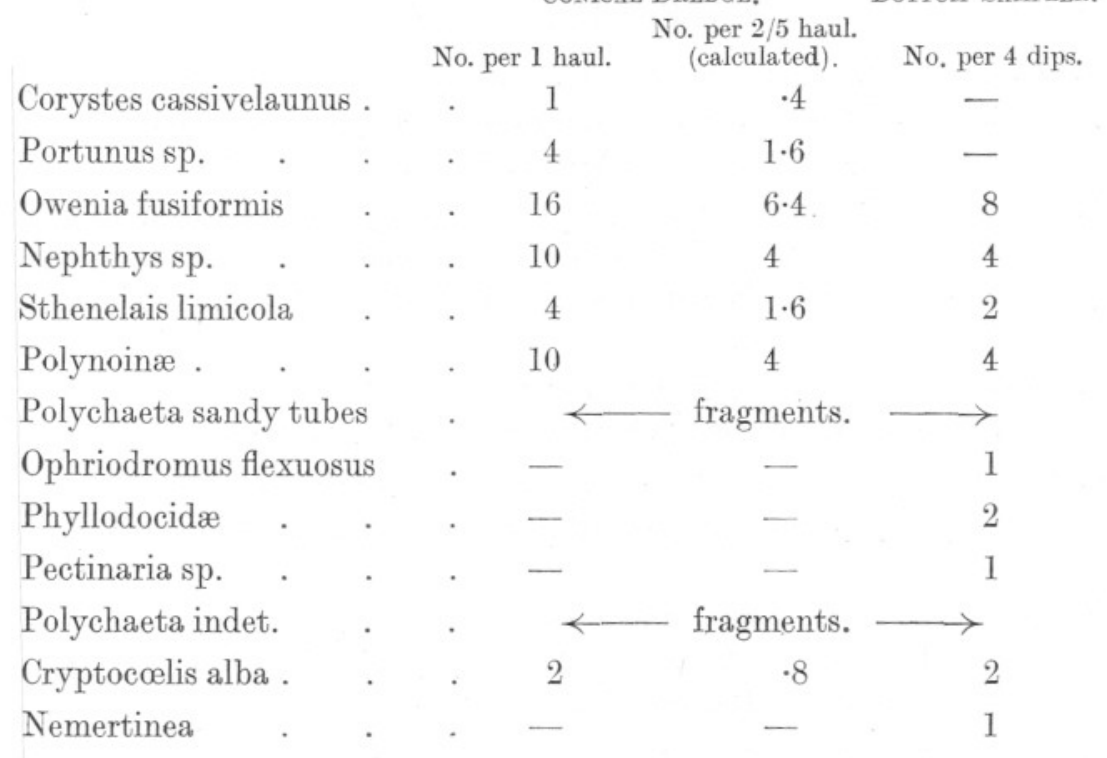

It would probably be unwise to pass too critical a judgment with the data of a single experiment of this kind, but the figures do show that the conical dredge is capable of taking a good sample under favourable circumstances, and will give a good idea of the general community formation. In this particular instance it has captured more species than the bottom-sampler, while none which are important items in the bottomsampler hauls are missing. Two interesting facts were observed which are not obvious from the tables. If age, as revealed by size, is taken into account, then a greater proportion of "O" group, Syndosmya alba, was taken by the conical dredge than by the bottom-sampler. This may indicate that the scraping action of the dredge when in tow may result in the capture of a relatively too high number of the surface animals? In the second place, the specimens of Amphiura filiformis obtained by the dredge were all badly broken, much more so than one would have expected notwithstanding the extreme ease with which these animals break up ordinarily. This may also be explained by the method of working, and serves to illustrate the advantage held by the bottom-sampler that it will bring up in excellent condition delicate organisms which would almost certainly be smashed by the dredge. Specimens of Corymorpha nutans, Virgularia mirabilis, and Cryptocolis alba have been obtained in splendid condition during recent months. 


\section{LITERATURE CITED.}

1. Allen, E. J. 1899. On the Fauna and Bottom Deposits near the Thirty-Fathom Line from the Eddystone Grounds to Start Point. Journ. Mar. Biol. Assoc., Vol. V, No. 4.

2. Bleggvad, H. 1914. Food and Conditions of Nourishment among the Communities of Invertebrate Animals found on or in the Sea Bottom in Danish Waters. Report XXII from the Danish Biological Station.

3. Petersen, C. G. Joh., and Boysen Jensen, P. 1911. Valuation of the Sea. I. Report XX from the Danish Biological Station.

4. Petersen, C. G. Joh. 1913-14. Valuation of the Sea. II. Report XXI from the Danish Biological Station, and Appendix to Report XXI (1914).

5. Petersen, C. G. JoH. 1915. On the Animal Communities of the Sea Bottom in the Skagerak, the Christiania Fjord, and the Danish Waters. Report XXIII from the Danish Biological Station.

6. Petersen, C. G. ЈoH. 1918. A Survey of the Work done in connection with Valuation of the Danish Waters from 1883-1917. Report XXV from the Danish Biological Station.

\section{VALUATION LISTS.}

A. Hauls of 1/10 sq. metre Bottom-Sampler at selected Stations, 1922-23

Plymouth Sound

PAGE

Vf stations

195

Mixed Vf and Vg stations

$\mathrm{Vg}$ stations

1. EcVg mud dominant

2. Mixed $\mathrm{EcVg}$ mud and b

3. $\mathrm{Vg}$

Outside waters

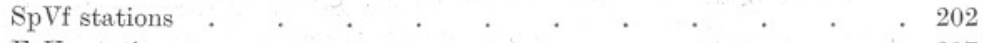

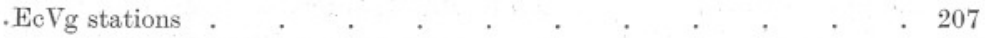

1. Vg stult. $+\mathrm{Ec} \quad$. $\quad$. . . . . . . . . . 207

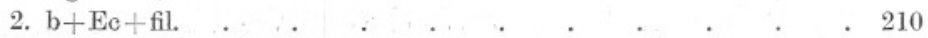

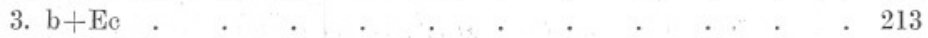

4. (b). . . . . . . . . . . . . . . . . . . 215

5. $\mathrm{EcVg}$ mud . . . . . . . . . . . 218

6. $\mathrm{Vg}+$ Turritella communis . $\quad . \quad$. $\quad . \quad . \quad . \quad . \quad 219$

7. $\mathrm{Vg}+$ Nucula nucleus $\quad . \quad$. $\quad . \quad . \quad . \quad . \quad 220$

B. Mr. J. R. Baker's hauls with Conical Dredge, July-September, 1921

1. Mud . . . . . . . . . . . . . . . 221

2. Sand . . . . . . . . . . . . . . . . 222

3. Shell gravel . . . . . . . . . . . . . . 224 


\section{PLYMOUTH SOUND. VF STATIONS.}

No. 23.

Per $\frac{1}{2} \mathrm{~m}^{2}$.

Nucula radiata

Tellina pusilla

Lutraria oblonga (juv.) .

Spisula elliptica (juv.) .

Dosinia exoleta

Dosinia lupina

Venus fasciata

Venus ovata.

Tapes virgineus

Gari tellinella

Ensis arcuata (juv.

Saxicava arctica

Echinocyamus pusillus

Urothoe marina

Hippomedon sp.

Nototropis vedlomensis

Leucothoe spinicarpa

Schizopoda.

Nephthys sp.

Lanice conchilega

Terebellidæ .

Polychaete tubes

Ascididæ with hydroids .

Off New Grounds Buoy. Shelly gravel. June 22nd, 1922.
No. No. 35 .

Per $\frac{1}{2} \mathrm{~m}^{2}$.

No. $\begin{array}{llll}\text { Nucula radiata } & \text {. } & \text {. } & \text {. }\end{array}$

Barbatia lactea . . . 1

Lima loscombi . . . 1

Lutraria oblonga (juv.) . $\quad .57$

Tellina pusilla . . . 2

Tellina crassa . . . . 1

Spisula elliptica (juv.) . . $\quad$. 287

Dosinia exoleta . . . 3

Venus fasciata . . . 20

Venus casina . . . 1

Cardium nodosum. . . 2

Gari tellinella . . . 1

Corbula gibba . . . 1

Solecurtus antiquatus . . 1

Ensis arcuata (juv.) . $\quad .9$

Natica alderi $\quad$. $\quad$. 1

Echinocyamus pusillus . . 3

Asterias sp. (juv.) . . . 1

Corystes cassivelaunus (juv.) . 1

Eupagurus sp. (juv.) . . 2

Glycera sp. . . . . 3

Lumbriconereis sp. . . 1

Terebellidæ . . . . 1

Ampharetidæ $\quad . \quad$. 1

Ammodytes lanceolatus (juv.). 1

Actinia - . $\quad$. 1

West Channel off Breakwater Lighthouse. Coarse shelly gravel with some stones. July 5th, 1922. 


\section{PLYMOUTH SOUND. VF STATIONS-continued.}

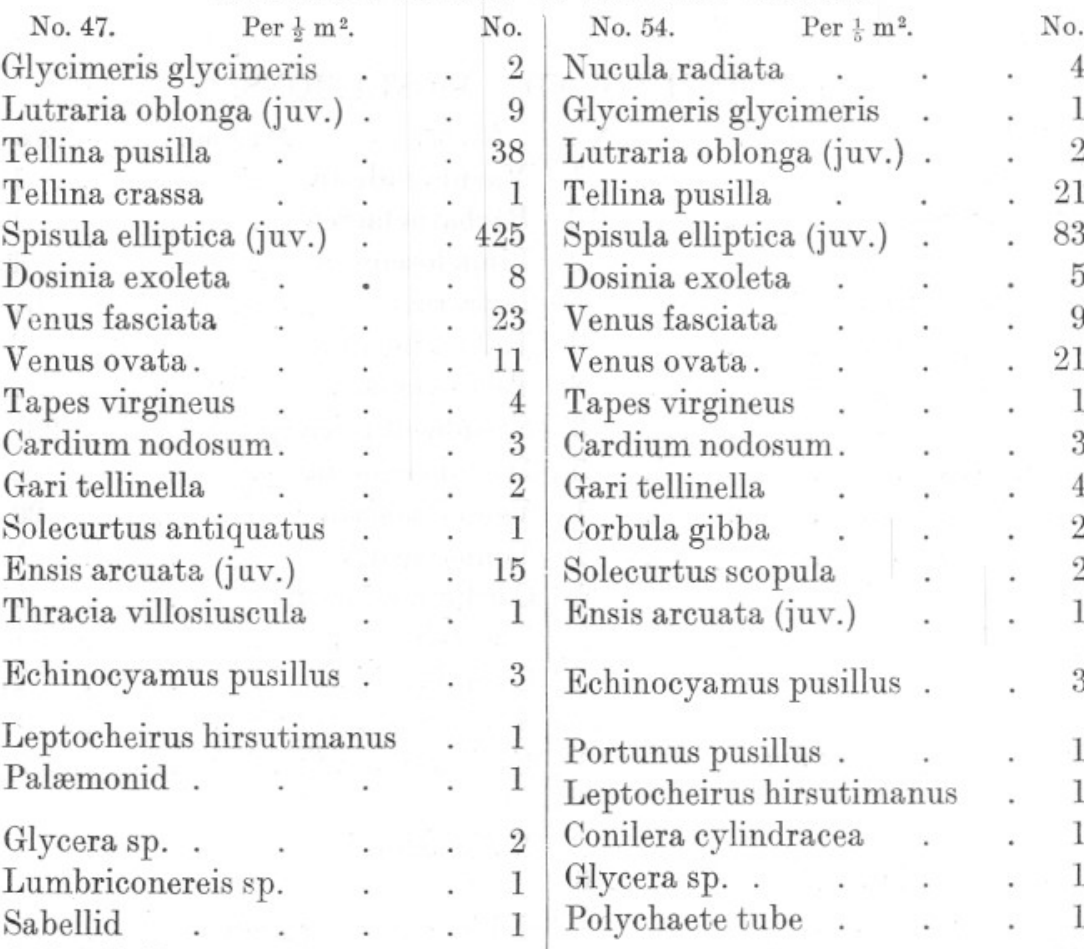

Aphroditidæ $\quad$. $\quad . \quad$. 1

Between New Grounds and Queen's Grounds Buoys. Coarse shelly gravel. July 25th, 1922.
Midway between New Grounds and Queen's Grounds Buoys. Coarse shelly gravel. September 19 th, 1922 .

\begin{tabular}{|c|c|c|c|c|c|c|}
\hline No. 89. & \multicolumn{2}{|c|}{ Per $\frac{1}{2} \mathrm{~m}^{2}$. } & No. & Per ${ }_{5}^{1} \mathrm{~m}^{2}$. & Per ${ }_{5}^{1} \mathrm{~m}^{2}$. & No. \\
\hline Tellina pusilla & . & . & 1 & Nucula radiata & . & 1 \\
\hline Tellina donacina & . & . & 1 & rassa & . & 1 \\
\hline iptica ( & (juv.) & . & 17 & Spisula elliptica (juv.) & . & 5 \\
\hline Gari & . & . & , & $\mathrm{Vel}$ & . & 2 \\
\hline Ensis & . & . & 1 & (juv.) & . & 1 \\
\hline 3 aren & nariu & & & $\mathrm{L}$ & . & \\
\hline & & & & p. : & . & 1 \\
\hline Nephihys sp. & . & $\cdot$ & 2 & crates arenarius & & \\
\hline & & & & Gl & . & \\
\hline & & & & ter & & \\
\hline $\begin{array}{l}\text { Ofif Bovisand } \\
\text { ravel. Februar }\end{array}$ & Pie & & & $\begin{array}{l}\text { Off New } \\
\text { gravel. F }\end{array}$ & 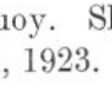 & \\
\hline
\end{tabular}




\section{PLYMOUTH SOUND. VF STATIONS-continued.}

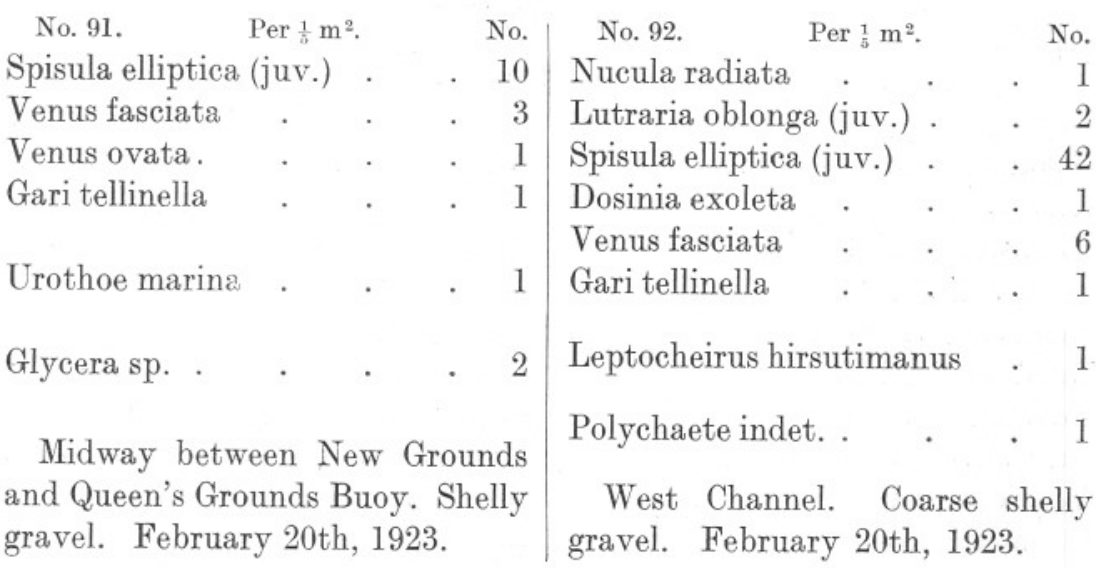

\section{PLYMOUTH SOUND. MIXED VF AND VG STATIONS.}

\section{No. 29. Per $\frac{1}{2} \mathrm{~m}^{2}$.}

Nucula nitida . . . 1

Syndosmya alba . . . 1

Tellina pusilla . . . . 1

Lutraria elliptica (juv.) . . 14

Spisula elliptica (juv.) . . 5

Spisula subtruncata . . 2

Venus ovata. . . . . 1

Tapes virgineus . . . . 1

Cardium echinatum (juv.) . 1

Cardium nodosum. . . 1

Cultellus pellucidus (et juv.) . 11

Ensis ensis (juv.) . . . 14

Ensis arcuata (juv.) . . 23

Schizopoda . . . . 1

Nephthys sp. . . . . 2

Lumbriconereis sp. . . $\quad 3$

Goniada maculata. . . 2

Lanice conchilega (small) • 4

Melinna adriatica (tubes) . 4

Cirratulids (small) . . 2

Off Melampus Buoy. Mixed gravel, sand, and mud. June 26th, 1922.

\section{No. 37.}

Per. $\frac{1}{2} \mathrm{~m}^{2}$.

Lucina borealis (juv.)

Spisula elliptica (juv.)

.

Spisula subtruncata . . 1

Dosinia lupina . . . 1

Dosinia exoleta . . . 1

Venus fasciata . . . 1

Venus casina $\quad . \quad . \quad . \quad 1$

Venus ovata. $\quad . \quad . \quad . \quad 1$

Tapes virgineus . . . 3

Cardium echinatum . . 1

Corbula gibba . . . 1

Cultellus pellucidus (et juv.) . 13

Ensis ensis (juv.) . . . 2

Ensis arcuata (juv.) . $\quad$. 10

Leptocheirus hirsutimanus . 1

Nephthys sp. . . . 3

Lumbriconereis sp. . . 2

Polynoid . . . . 1

Polychaete tubes . . . 3

Nemertini . . . . 1

Off Melampus Buoy. Mixed shelly gravel and sand. July 10th, 1922. 
PLYMOUTH SOUND. STATIONS WHERE EcVG MUD IS DOMINANT.

\section{No. 24. $\operatorname{Per} \frac{1}{2} \mathrm{~m}^{2}$.}

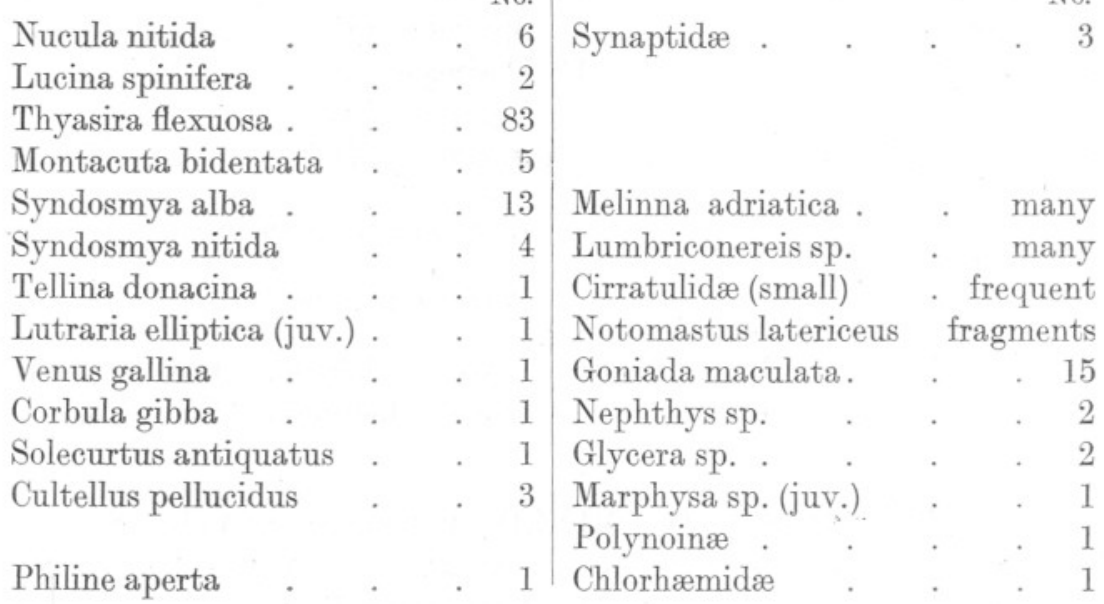

Jennycliff Bay. Off Inner Hospital Ship. Black mud. June 22nd, 1922.

No. 25. $\operatorname{Per} \frac{1}{2} \mathrm{~m}^{2}$.

No. No.

Nucula nitida . . 25

Thyasira flexuosa. . . 43

Montacuta bidentata . . 2 Melinna adriatica . . many

Syndosmya alba . . . 12 Lumbriconereis sp. . many

Spisula subtruncata . . 1 Cirratulidæ . . . . 5

Venus gallina $\quad . \quad$. 11 Notomastus latericeus . fragments

Venus ovata. $\quad . \quad$. 11 Goniada maculata . 8

Cardium echinatum (juv.) . $\quad 1$ Nephthys sp. . . . $\quad 2$

Cardium nodosum. . . 1 Glycera sp. . . . . . 3

Corbula gibba . . $\quad$. 1 Marphysa sp. (juv.) . . 4

Cultellus pellucidus . $\quad . \quad 3$ Nereis sp. . . . . . 2

Magelona papillicornis . 6

Philine aperta . . $\quad 2$ Maldanidæ : ${ }_{\text {Polychaetes indet. }} \cdot 5$

Synaptidæ . . . $\quad 2 \quad$ Nemertini . . . . 1

Jennycliff Bay. Off Outer Hospital Ship. Black mud with some sand. June 26th, 1922. 
PLYMOUTH SOUND. STATIONS WHERE EoVG MUD IS DOMINANT-contd.

No, 30

Lucina borealis

Thyasira flexuosa.

Montacuta bidentata

Syndosmya alba

Lutraria elliptica (juv.) .

Venus gallina

Venus verrucosa

Tapes virgineus

Tapes pullastra

Cardium fasciatum

Gari ferrœensis

Mya truncata

Corbula gibba

Cultellus pellucidus

Calyptræa chinensis

Antedon bifida

Eupagurus sp. (juv.)

Portunus sp. (juv.)

Melinna adriatica . . many

Cirratulidæ (small) . many

Nephthys sp.

Lumbriconereis sp.

Goniada maculata

Magelona papillicornis

Nereis sp.

Marphysa sp.

Sthenelais sp.

Polynoinæ

Nemertini

Cereus pedunculatus . . 4

Sagartia sp. . . . . 2

Midway between Mallard Buoy and Batten Breakwater. Black mud with clinker. June 26th, 1922.

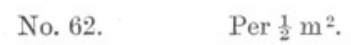

No. 62 .

Per $\frac{1}{2} m^{2}$.

No.

Nucula nitida . . . 3

Modiolaria marmorata . . 1

Lucina borealis . . . 10

Thyasira flexuosa. . . 10

13 Montacuta bidentata . . 1

4 Syndosmya alba . . . 17

1 Dosinia lupina . . . 2

4 Tapes virgineus . . . 3

32 Tapes pullastra . . . . 35

1 Tapes perforans . . . . 1

1 Cardium fasciatum . . 3

7 Corbula gibba $\quad . \quad . \quad 3 \quad . \quad 34$

Mya truncata (juv.) . . 20

Solecurtus antiquatus . . 2

Saxicava rugosa . . . 1

Goniodoris castanea . . 1

Antedon bifida (juv.) . . 8

Ophiura sp. . . . . 1

Cucumaria elongata $\quad . \quad$. 1

Portunus sp. (juv.) . . 2

Carcinus maenas . . . 1

Lysianassa ceratina . . 9

Melinna adriatica . . . 6

Cirratulidæ . . . . 1

Nephthys sp. . . . 14

Lumbriconereis sp. . . 3

Goniada maculata . . 5

Nereis sp. . . . . 7

Polynoinæ . . . . 2

Sthenelais sp. $\quad$. $\quad . \quad$. 2

Notomastus latericeus . . 1

Nemertini . . . . 1

Ascididæ . . . . several

Midway between Mallard Buoy and Batten Breakwater. Black mud with clinker. October 26th, 1922. 
PLYMOUTH SOUND• STATIONS WHERE ECVG MUD IS DOMINANT-contd. No. 36. Per $\frac{1}{2} \mathrm{~m}^{2}$.

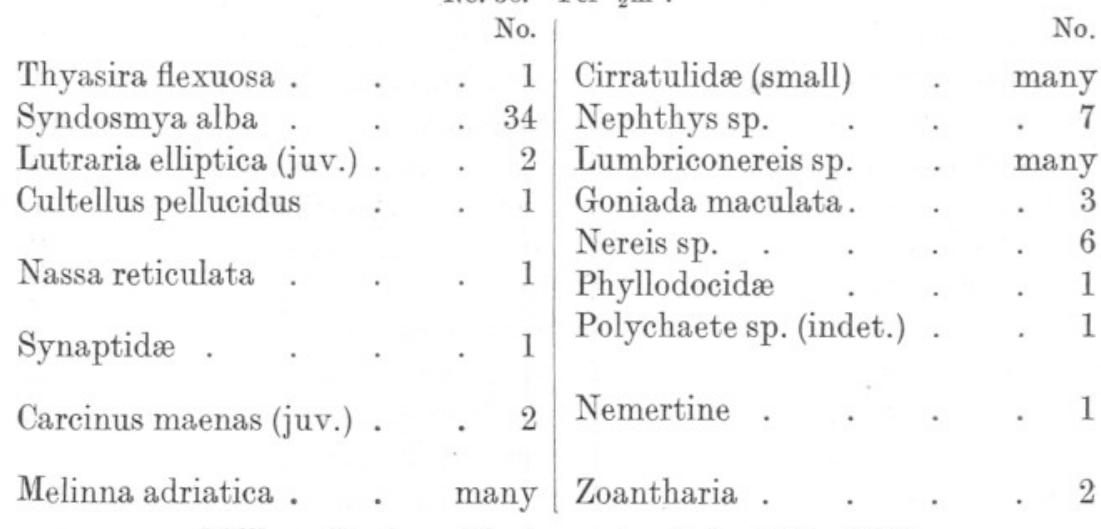

Millbay Docks. Black mud. July 10th, 1922.

No. 61. Per ${ }^{1} \mathrm{~m}^{2}$.

\begin{tabular}{|c|c|c|c|c|c|}
\hline & & & No. & & No. \\
\hline Nucula nitida & . & & 1 & Melinna adriatica . & many \\
\hline Lucina borealis & . & & 1 & Lumbriconereis sp. & . 10 \\
\hline Thyasira flexuosa & . & . & . 23 & Cirratulidæ. & . \\
\hline Syndosmya alba & . & - & 1 & Notomastus latericeus & fragments \\
\hline Dosinia lupina & . & & 1 & Goniada maculata & . \\
\hline Cultellus pellucidu & & - & 2 & Nephthys sp. & . \\
\hline Philine 9 & & & 1 & Owenia fusiformis (tube & \\
\hline Phillne & . & ${ }^{*}$ & 1 & Maldanidæ . & . \\
\hline Pycnogonida & . & & 1 & Myxicola (tube). & . \\
\hline Porcellana longicos & ornis & . & 1 & Nemertini . & . \\
\hline
\end{tabular}

Jennycliff Bay. Off Inner Hospital Ship. Black mud.

October 26th, 1922.

PLYMOUTH SOUND. MIXED EcVG MUD AND b STATIONS. No. 60 . Per $\frac{1}{2} \mathrm{~m}^{2}$.

No. No.

Nucula nitida $\quad . \quad$. $\quad 1$ Venus ovata . $\quad . \quad$. 1

Lucina borealis . . $\quad$. 1 Solecurtus antiquatus . 3

Thyasira flexuosa. . $\quad 13$ Cultellus pellucidus . $\quad$. 9

Syndosmya alba . . . 1 Melinna adriatica . frequent

Spisula subtruncata . . 1 Lumbriconereis sp. frequent

Dosinia lupina . . $\quad$. $7 \mid$ Notomastus latericeus fragments.

Midway between Duke Rock Buoy and No. 1 Anchorage Buoy. Sandy mud. October 26th, 1922. 
PLYMOUTH SOUND. MIXED EcVG MUD AND b STATIONS-continued.

No. 26. Per $\frac{1}{2} \mathrm{~m}^{2}$.

No. $\quad$ No.

Nucula nitida . . 11 Schizopoda . . . . 1

Lucina borealis . . . 3 Isopoda . . . . 1

Thyasira flexuosa. . . 28

Montacuta bidentata . . . 2

Syndosmya alba . . . . 14

Tellina fabula . . . .

Spisula subtruncata . .

Lutraria elliptica (juv.) . 6

Dosinia lupina (et juv.) . . 8

Venus ovata. . . . 12

Tapes virgineus . . . . 1

Corbula gibba . . . 24

Mya truncata (juv.) . $\quad$. 1

Cultellus pellucidus $\quad . \quad$. 10 Nemertini . . . . . 1

Portunus sp. (juv.) . $\quad$. $1 /$ Virgularia mirabilis . . 1

Off Duke Rock Buoy. Muddy sand. June 26th, 1922.

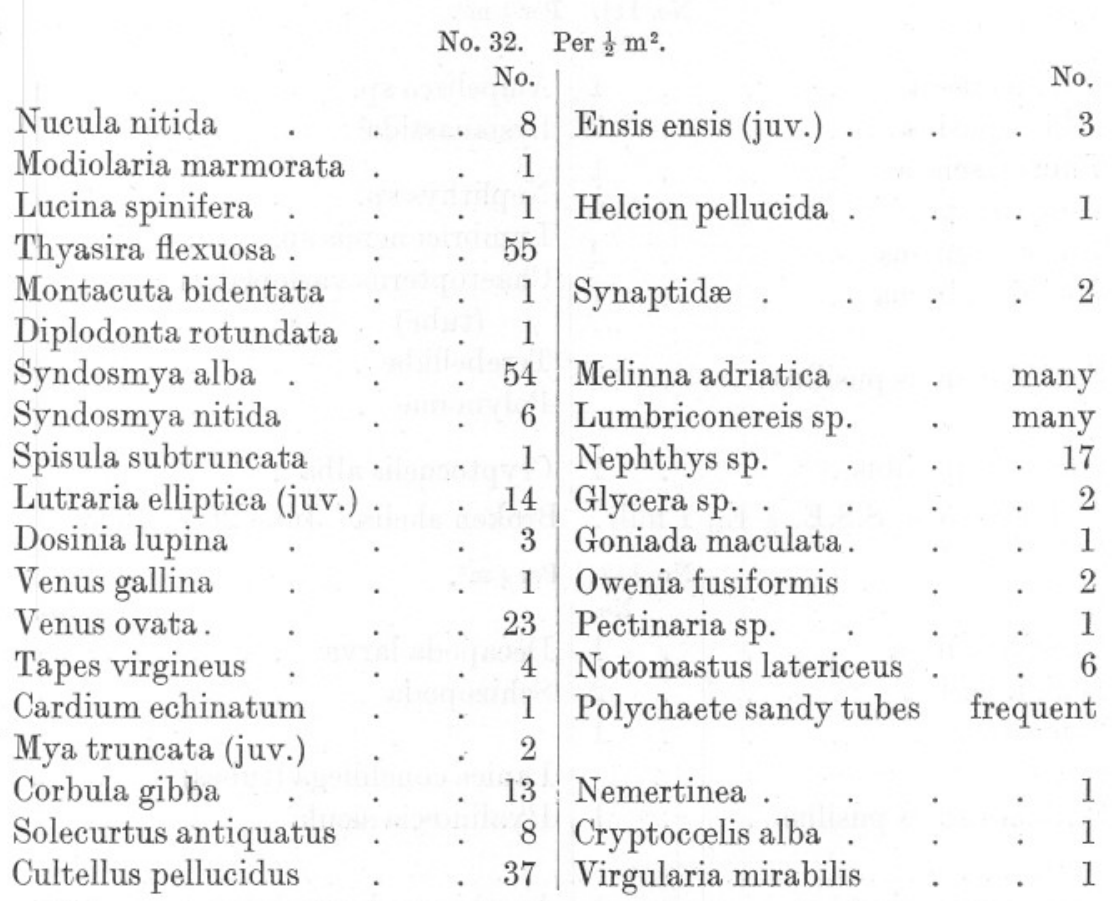

Midway between Duke Rock Buoy and No. 1 Anchorage Buoy.

Sandy mud. July 5th, 1922. 


\section{PLYMOUTH SOUND. VG STATION.}

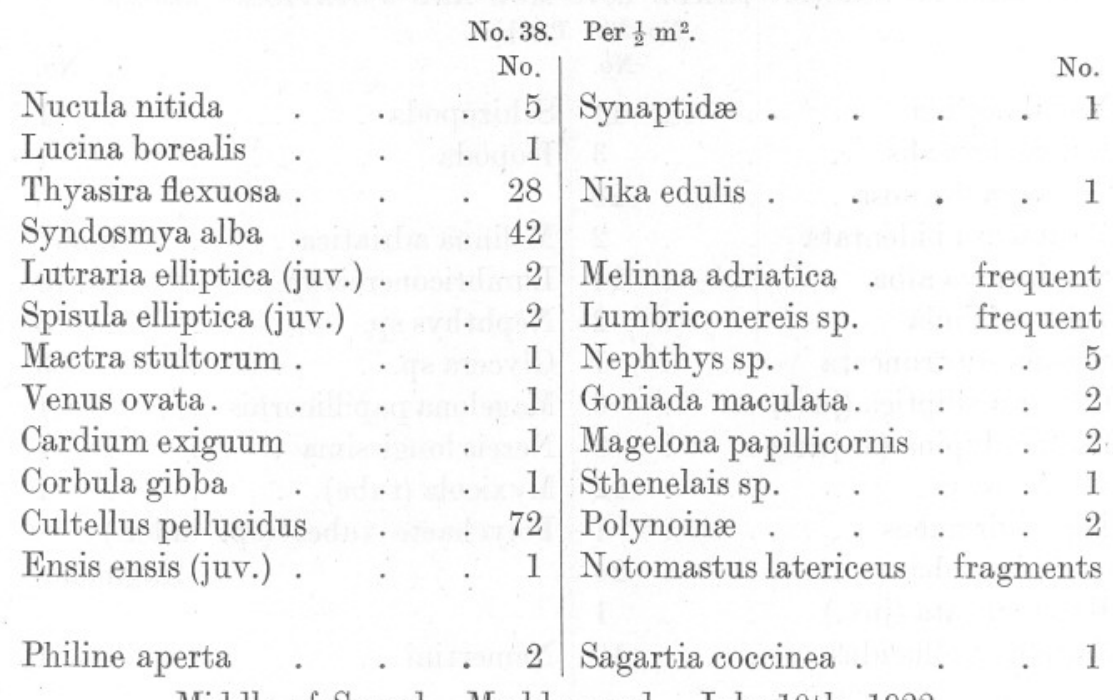

Middle of Sound. Muddy sand. July 10th, 1922.

OUTSIDE WATERS. SPVF STATIONS.

No. 111. $\operatorname{Per} \frac{1}{3} \mathrm{~m}^{2}$.

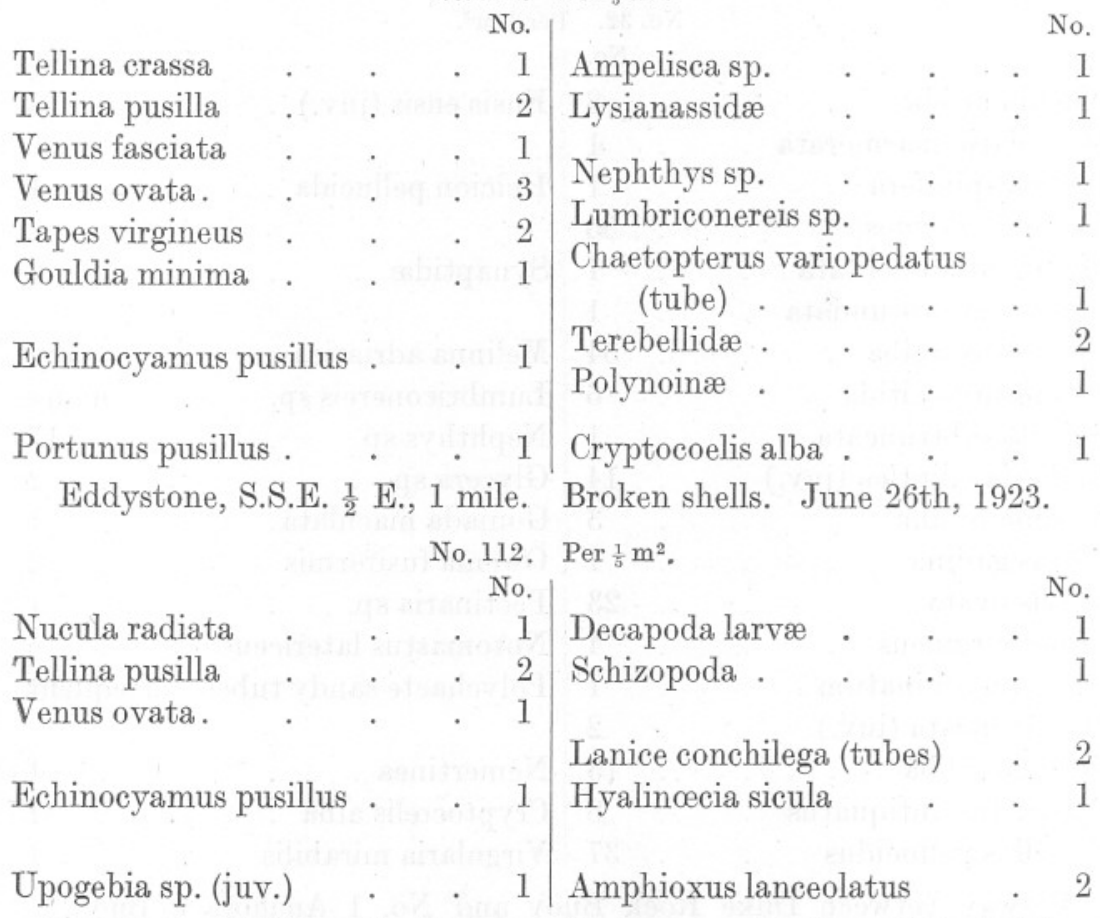

Eddystone, S.S.E. $\frac{1}{2}$ E., 3 miles. Shelly gravel. June 26 th, 1923. 
OUTSIDE WATERS, SPVF STATIONS-continued.

No. 14. Per $\frac{1}{2} \mathrm{~m}^{2}$.

No. $\quad$ No.

Venus ovata.

Urothoe marina . . . 1

Solecurtus scopula $\quad$. 1 Monoculodes carinatus . . 1

Echinocyamus pusillus . $\quad 2$ Polygordius sp. . $\quad$. $\quad$. 1

Ophiothrix fragilis . $\quad 1$ Lanice conchilega (tubes) fragments

Ophiocoma nigra . . . 1

Asterias rubens . . . 1 Amphioxus lanceolatus . . 1

Erme Head, N.E. by E., 2 miles. Clean shell gravel.

June 9th, 1922.

No. 20. Per $1 \mathrm{~m}^{2}$ 。

Nucula radiata

No. No.

Lima loscombi . . . 4 Ampelisca brevicornis . . 1

Tellina crassa . . . $\quad$. 1 Nototropis vedlomensis . . 1

Spisula elliptica (juv.) . . . 2

Venus fasciata . . . 21 Polygordius sp. . fragments

Venus ovata. . . . 13 Chaetopterus variopedatus

Tapes virgineus . . . $18 \quad$ (tubes) . $18 \quad . \quad$. 4

Gouldia minima . . . 11 Glycera sp. . . . . 13

Cardium fasciatum . $\quad$. 2 Lumbriconereis sp. . . . 4

Gari tellinella . . $\quad . \quad 4$ Polynoinæ . . . . 4.6

Cultellus pellucidus . $\quad$. 1 Pectinaria sp. 1 . . $\quad$. 2

Thracia villosiuscula . $\quad . \quad 1$ Lanice conchilega . . . . 4

Natica alderi .

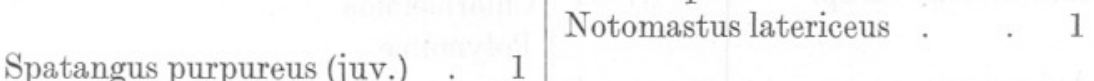

Echinocyamus pusillus . . 10 Cryptocœlis alba . . . 1

Porcellana longicornis . . 4

Portunus pusillus . . 4

Eurynome aspersa . $\quad .1$ Cellaria sp. . . fragments

Galathea sp. (juv.) $\quad$. $\quad$. $\quad 2$ Corymorpha nutans $\quad . \quad$. 1

Ebalia sp. . . . . 2

Decapoda postlarvæ . $\quad .44$ Amphioxus lanceolatus . $\quad 49$

Eddystone, S.S.E. $\frac{1}{2}$ E. $\frac{1}{2}$ mile. Clean shell gravel.

June 20th, 1922. 
OUTSIDE WATERS. SPVF STATIONS-continued.

\begin{tabular}{|c|c|c|c|}
\hline No. 81. & $\operatorname{Per} \frac{1}{2} r$ & & \\
\hline Glycimeris glyci & meris & & \\
\hline Tellina crassa & . & . & \\
\hline Tellina pusilla & . & . & \\
\hline Venus fasciata & . & & \\
\hline Venus ovata. & . & e & \\
\hline Tapes virgineus & 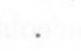 & & \\
\hline Gouldia minima & & & \\
\hline Cardium nodosu & $\mathrm{m}$. & & \\
\hline Cardium norveg & icum & & \\
\hline Gari tellinella & & & \\
\hline Solecurtus scop & & & \\
\hline Thracia villosiu & scula & & \\
\hline
\end{tabular}

Echinocardium flavescens (juv.) . . . 1

Echinoeyamus pusillus . . 3

Portunus pusillus . . . 2

Ebalia tuberosa . . . . 1

Ampelisca typica . . . 1

Maera sp. . . . . 2

Polygordius sp. . fragments

Glycera sp. . . . . 8

Polynoinæ . . . . 1

Lumbriconereis sp. ․ . 1

Aphroceras sp. . . . 1

Amphioxus lanceolatus . $\quad 18$

Eddystone, S.S.E. $\frac{1}{2}$ E. $\frac{1}{2}$ mile. Clean shell gravel. January 25th, 1923.
No. 95. Per $\frac{1}{2} \mathrm{~m}^{2}$.

No.

Nucula radiata . $\quad . \quad$. 1

Glycimeris glycimeris . . 7

Tellina crassa . . . . 4

Tellina pusilla . . . 4

Spisula elliptica (juv.) . . 2

Venus fasciata $\quad$ ? 7

Venus ovata. . . . 4

Tapes virgineus . . . . 4

Gouldia minima . . . . 5

Gari tellinella . . . 11

Echinocardium flavescens . 1

Echinocyamus pusillus . $\quad$. 8

Cucumaria sp. . . . $\quad$. 1

Ophiuroid (juv.) . $\quad$. $\quad$. 1

Atelocyclus (juv.) . . . 1

Zоæа . $\quad . \quad$. $\quad . \quad . \quad 1$

Isopoda . . . . . 1

Ampelisca spinipes . . 2

Ampelisca sp. . . . 1

Maera sp. . . . . 3

Gammaridae . . . 2

Glycera sp. . . . . 4

Lumbriconereis sp. . . 1

Chlorhæmids . . . 2

Polynoinæ . . . . 1

Polygordius sp. $\quad . \quad$. $\quad . \quad 1$

Corymorpha nutans . . 8

Amphioxus lanceolatus . 9

Eddystone, S.S.E. $\frac{1}{2}$ E. $\frac{1}{2}$ mile. Clean shelly gravel. May 9 th, 1923. 
OUTSIDE WATERS. SPVF STATIONS-continued.

No. 102. $\quad \operatorname{Per} \frac{1}{10} \mathrm{~m}^{2}$.

Glycimeris glycimeris

Tellina donacina.

Venus fasciata

Venus ovata .

Tapes virgineus

Cardium nodosum.

Gari tellinella

Solecurtus scopula

Echinocyamus pusillus .

Ophiura sp. .

Ampelisca sp.

Maera sp.

Polynoinæ

Nephthys sp.

Owenia fusiformis

Polychaetes indet. .

Knight Errant Buoy, N.N.W. $\frac{1}{4}$ mile. Coarse shell gravel with some silt. June 5th, 1923.
No. No. 52. Per $\frac{1}{2} \mathrm{~m}^{2}$.

No.

Tellina pusilla . . . 3

Tellina crassa . . . 1

Lutraria oblonga (juv.) . . 2

Spisula elliptica (juv.) . . . 47

Dosinia sp.(juv.) . . . 8

Venus fasciata . . . 3

Venus ovata. $\quad \ldots \quad \ldots \quad \ldots 1$

Gari tellinella . . . . 1

Ensis arcuata (juv.) . . 2

Echinocyamus pusillus . $\quad 1$

Eupagurus sp. (juv.) . . 1

Cirolana gallica . . . 1

Pontocrates arenarius . $\quad$. 1

Glycera sp. . $\quad$. $\quad$. $\quad$. 1

Breakwater Light, E. by N. $\frac{1}{2}$ N., $\frac{3}{4}$ mile. Small gravel with shell fragments and pieces of shale. July 31st, 1922. (b)

Glycimeris glycimeris . . 3

Tellina pusilla . . . . 1

Venus fasciata . . . 4

Venus ovata. $\quad$. $\quad 1$

Venus casina $\quad . \quad$. 1

Echinocyamus pusillus . $\quad 1$

(many dead)

Ampelisca spinipes . 1

Nephthys sp. . . . 1

Syllidæ . . . . . 1

Amphioxus lanceolatus . $\quad$. 1

Eddystone, S.W. $\frac{3}{4}$ S., $1 \frac{1}{2}$ miles. Muddy coarse shell gravel. August 14th, 1922.
$\operatorname{Per} \frac{1}{10} \mathrm{~m}^{2}$

(c) No.

Glycimeris glycimeris . $\quad$. 1

Venus ovata. $\quad . \quad$. 1

Cultellus pellucidus . . 3

Ampelisca spinipes $\quad$. $\quad$. 1

Nephthys sp. $\quad . \quad$. $\quad . \quad 1$

Lanice conchilega (tube) . 1

Mewstone, E.N.E. Tregantle, N. by E. $\frac{1}{4}$ E. Mixed sand, shells, and coarse material. August 14th, 1922. 
OUTSIDE WATERS. SPVF STATIONS-continued.

No. 65 . $\quad$ Per $\frac{1}{2} \mathrm{~m}^{2}$.

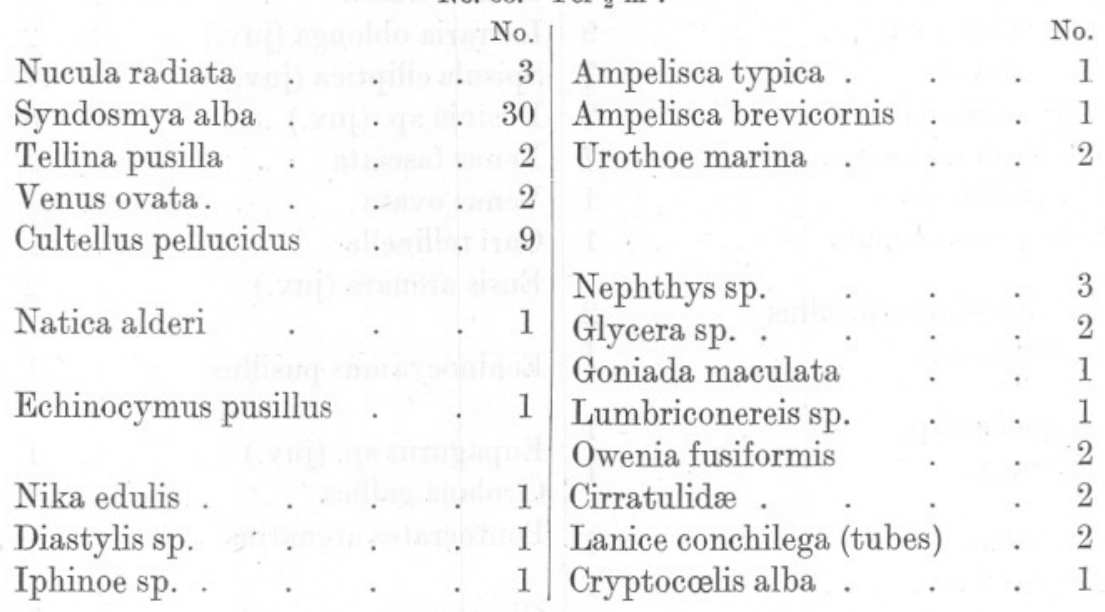

Erme Coast Guard Station, N.E. northerly. Borough Island, E.

Fine shell gravel. October 31st, 1922.

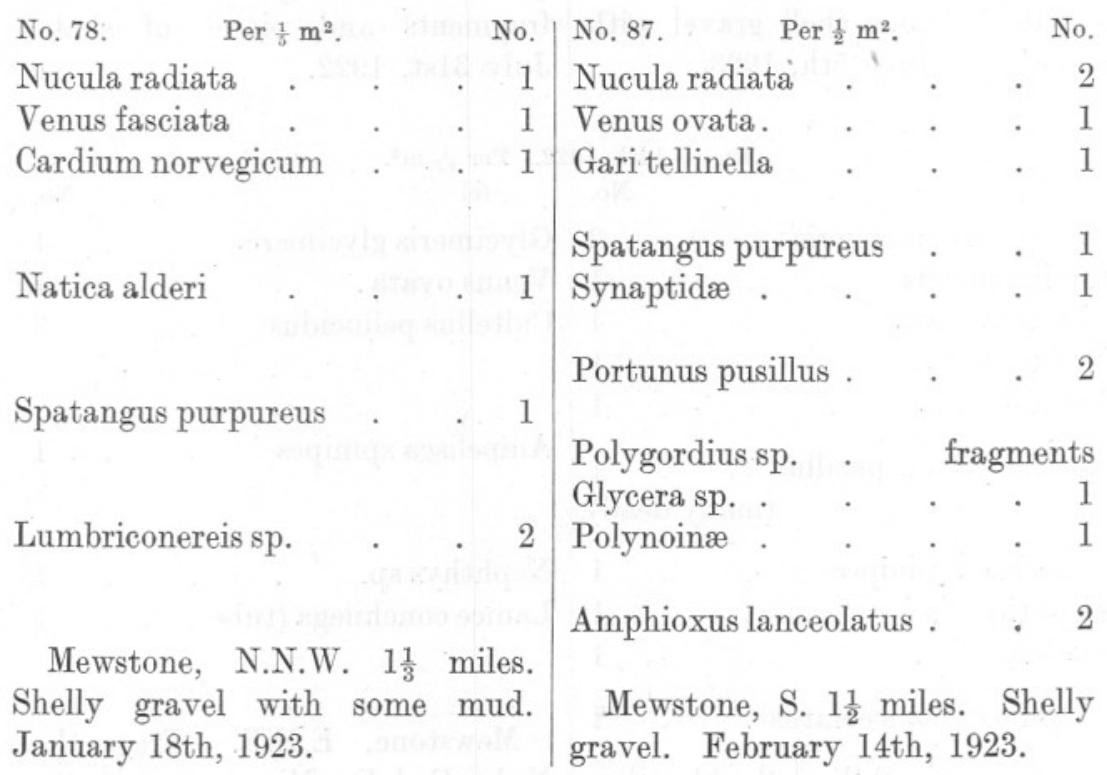


OUTSIDE WATERS. VG STULT + EC STATIONS.

No. 12. Per $1 \mathrm{~m}^{2}$.

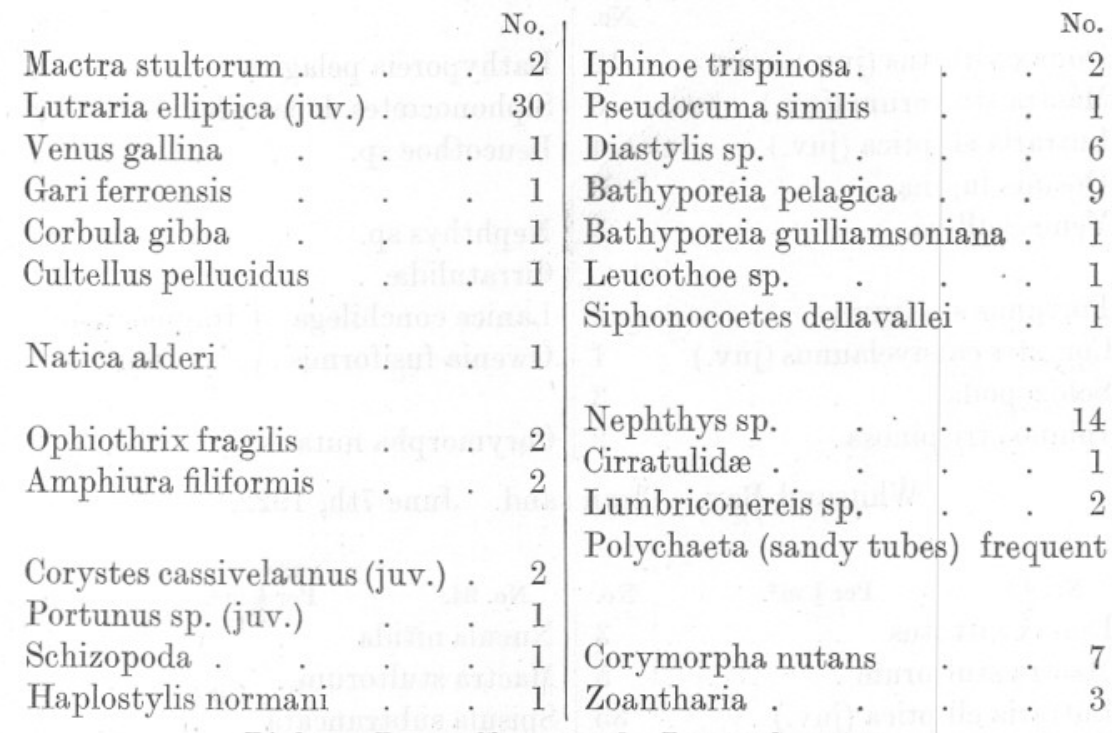

Bigbury Bay. Clean sand. June 9th, 1922.

No. 64. Per $\frac{1}{2} \mathrm{~m}^{2}$.

Mactra stultorum .

Venus gallina

Echinocardium cordatum

Iphinoe trispinosa.

Diastylis sp.

Bathyporeia pelagica

Bathyporeia guilliamsoniana .

Hippomedon denticulatus . 3

Nephthys sp.

Lanice conchilega .

Magelona papilli

gelona papilicornis . . 1

Owenia fusiformis . . 1

Phyllodocid . . . . 1

Polychaeta (sandy tubes)

fragments

Bigbury Bay. Clean sand. October 31st, 1922 .

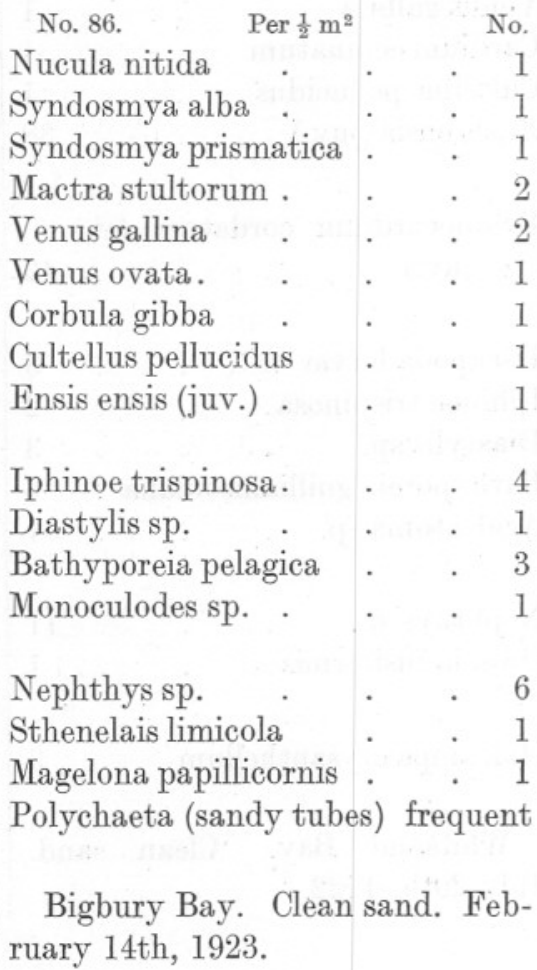


OUTSIDE WATERS. VG STULT+Ec STATIONS-continued.

No. 8. Per $1 \mathrm{~m}^{2}$.

No.

Donax vittatus (juv.) . . 12 Mactra stultorum (juv.) . 6

Lutraria elliptica (juv.) . . 4

Dosinia lupina . . . 3

Venus gallina $\quad . \quad . \quad . \quad 1$

Portunus sp. (juv.)

Corystes cassivelaunus (juv.)

Schizopoda. . . . 3

Iphinoe trispinosa.
Bathyporeia pelagica . . 3

Siphonocœtes dellavallei . 1

Leucothoe sp. . . . . 1

Nephthys sp. . . . 23

Cirratulidæ . . . . 2

Lanice conchilega ) fragments of

Owenia fusiformis $\}$ tubes

2 Corymorpha nutans . . 1

Whitsand Bay. Clean sand. June 7th, 1922.

$\begin{array}{llllll}\text { No. } 43 . & \text { Per } \frac{1}{2} \mathrm{~m}^{2} \text {. } & \text { No. } & \text { No. } 94 . & \text { Per } \frac{1}{2} \mathrm{~m}^{2} \text {. } & \text { No. }\end{array}$

Donax vittatus . . . 3 Nucula nitida . . $\quad$. 2

Mactra stultorum . . . 5 Mactra stultorum . . . 5

Lutraria elliptica (juv.) . $\quad 35$ Spisula subtruncata . . 3

Dosinia lupina . $\quad . \quad 1$ Lutraria elliptica . $\quad . \quad$. 3

Venus gallina . $\quad . \quad$. 1 Venus gallina . . . 5

Cardium echinatum . 1 Meretrix chione (juv.) . . 5

Cultellus pellucidus . $\quad . \quad 1$ Corbula gibba . . . 1

Ensis ensis (juv.) . $\quad$. $\quad .38$

Echinocardium cordatum (et juv.) . . . . 43

Echinocardium cordatum . 2

Echinocyamus pusillus . . 1

Ophiura sp. (juv.) . $\quad$. 5

Decapoda larvæ . . $\quad 35$ Schizopoda . . . 3

Iphinoe trispinosa. . . 2 Iphinoe trispinosa . . 1

Diastylis sp. $\quad 3$ Bathyporeia pelagica . . 5

\begin{tabular}{ll|l} 
Bathyporeia guilliamsoniana & 6 & Bathyporeia guilliamsoniana . 4
\end{tabular}

Acidostoma sp. . . 11 Pontocrates sp. . . . 1

Nototropis vedlomensis . . 1

Ceradocus semiserratus . . 1

Nephthys sp. . . . 11

Owenia fusiformis $\quad$. 1

Halcampa crysanthellum . 3

Nephthys sp. $\quad$. $\quad$. $\quad$. 9

Owenia fusiformis . . 1

Polychaeta (sandy tubes) . 2

Whitsand Bay. Clean sand. Whitsand Bay. Clean sand. \begin{tabular}{l|l} 
July 20th, 1922. & February 20th, 1923.
\end{tabular} 
OUTSIDE WATERS. VG STULT+EC STATIONS-continued.

No. 9. Per $1 \mathrm{~m}^{2}$.

No. $\quad$ No.

Donax vittatus . . $\quad 2$ Corystes cassivelaunus (juv.) . 1

Mactra stultorum (juv.) . 8 Bathyporeia pelagica . . 4

Lutraria elliptica (juv.) . . 14 Bathyporeia guilliamsoniana . 4

Dosinia lupina . . . 3 Leucothoe sp. . . . 1

Venus gallina . . . 7 Urothoe sp. . . . . 1

Ensis ensis (juv.) . . $\quad 3$ Hippomedon denticulatus . 1

Natica alderi $\quad . \quad$. $\quad . \quad 1$ Nephthys sp. $\quad$. $\quad . \quad 24$

Astropecten irregularis . . 1 Polychaeta sp.indet. fragments

Polychaeta, sandy tubes fragments

Portunus sp. (juv.) . $\quad$. $1 /$ Corymorpha nutans . $\quad .4$

Galathea sp.(juv.) . . $1 /$ Zoantharia . . . . 2

Whitsand Bay. Clean sand. June 7th, 1922.

No. 109. $\operatorname{Per} \frac{1}{2} \mathrm{~m}^{2}$.

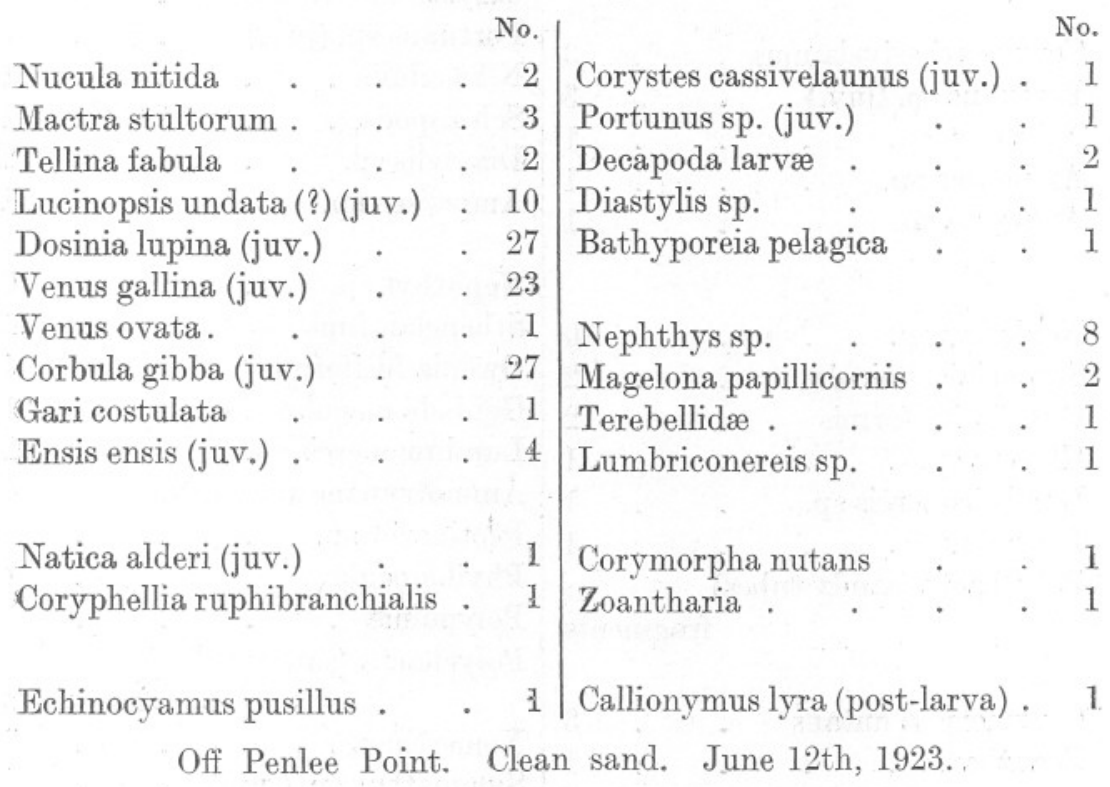


OUTSIDE WATERS. $\mathrm{b}+\mathrm{Ec}+\mathrm{FIL}$. STATIONS.

\begin{tabular}{|c|c|c|c|}
\hline Per $\frac{1}{2} m^{2}$. & No. & Per $\frac{1}{2} \mathrm{~m}^{2}$. & No. \\
\hline Nucula nitida & . 24 & Nucula nitida & 20 \\
\hline Thyasira flexuosa. & 6 & Lucina borealis & . \\
\hline Montacuta bidentata & . 24 & Montacuta bidentata & . 22 \\
\hline Diplodonta rotundata & 1 & Syndosmya alba . & . 940 \\
\hline Syndosmya alba . & . 900 & Syndosmya prismatica & . \\
\hline Spisula subtruncata & 2 & Mactra stultorum . & . \\
\hline Venus gallina & 2 & Venus gallina & . \\
\hline Venus ovata. & 1 & Venus ovata. & . \\
\hline Cardium echinatum & . & Cardium echinatum & . 15 \\
\hline Gari ferrœnsis & 1 & Corbula gibba & . \\
\hline Corbula gibba & 3 & Cultellus pellucidus & . 39 \\
\hline Cultellus pellucidus & . 14 & & \\
\hline & & Ideri & . \\
\hline Echinocardium cordatur & & Bullinella & • \\
\hline Amphiura filiformis & . 110 & Echinocardium cordatur & \\
\hline Ophiura ciliaris . & . 12 & Amphiura filiformis & . \\
\hline Ophiothrix fragilis . & . & Ophiura ciliaris . & . \\
\hline Synaptidæ . & . & & \\
\hline & & cassivelaunus & ${ }^{\circ}$ \\
\hline Corystes cassivelaunus & . & Portunus sp. (juv.) & - \\
\hline Portunus sp. (juv.) & . & dulis . & . \\
\hline Nika edulis. & . & Schizopoda . & . \\
\hline Ampelisca sp. & . & Diastylis sp. & . \\
\hline Apherusa sp. & . & Ampelisca sp. & . \\
\hline & & $\mathrm{N}$ & . \\
\hline Nephthys sp. & . 10 & limicola & . \\
\hline Sthenelais limicola & 2 & tsiformis & . \\
\hline Owenia fusiformis & 2 & da maculata. & . \\
\hline Glycera sp. . & 1 & Lumbriconereis sp. & . \\
\hline Lumbriconereis sp. & 1 & Ammotrypane aulogaste & er \\
\hline Polynoinæ . & 1 & Pectinaria sp. & . 13 \\
\hline Polychaeta (sandy tubes & & Phyllodocidæ & . \\
\hline & fragmen & $\begin{array}{l}\text { Polynoinæ } \\
\text { Polychaeta (sandy tube }\end{array}$ & es) \\
\hline Corymorpha nutans & 5 & & fragme \\
\hline Zoantharia . & . & $\begin{array}{l}\text { Nemertinea . } \\
\text { Svngnathus sp. (juv.) }\end{array}$ & $\cdot$ \\
\hline $\begin{array}{l}\text { Bigbury Bay. Borou } \\
\text { N.E. Bolt Tail, S.E. b } \\
\text { sand. June } 9 \text { th, } 1922 \text {. }\end{array}$ & $\begin{array}{l}\text { ugh Islan } \\
\text { by S. Sil }\end{array}$ & $\begin{array}{l}\text { Bigbury Bay. Borov } \\
\text { N.E. by E. Bolt Tail } \\
\text { Silty sand. October } 31\end{array}$ & $\begin{array}{l}\text { ugh Islan } \\
\text { l, S.E. } \frac{1}{2}\end{array}$ \\
\hline
\end{tabular}


OUTSIDE WATERS. b+Ec+FIL. STATIONS-continued.

No. 85. $\operatorname{Per} \frac{1}{2} \mathrm{~m}^{2}$.

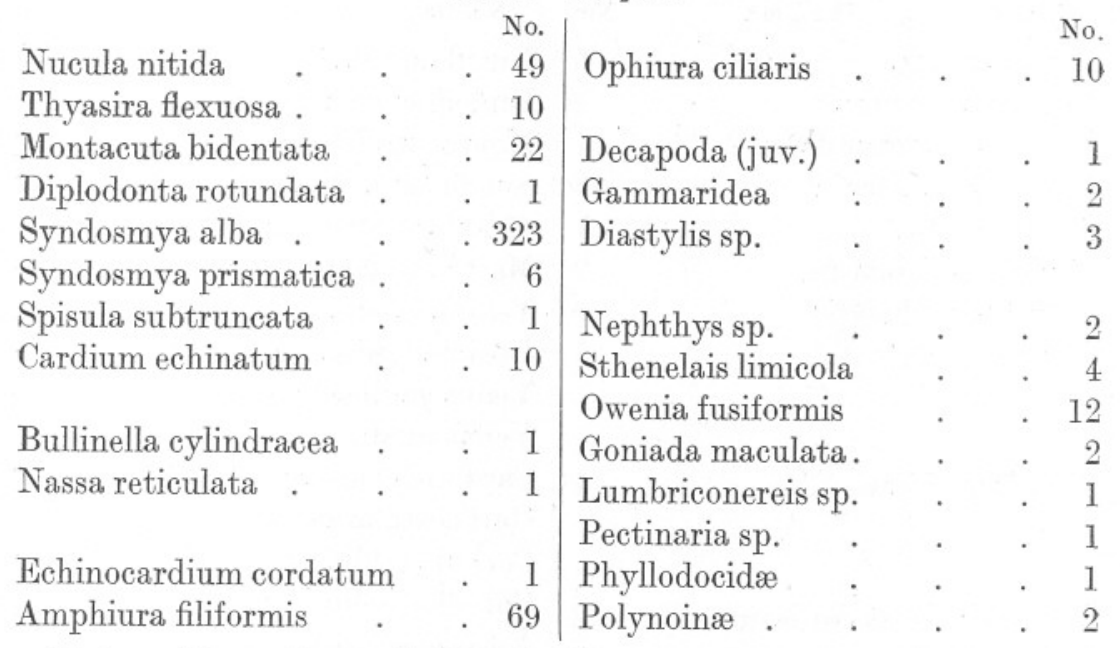

Bigbury Bay. Borough Island, N.E. by E. Bolt Tail, S.E. by S. Silty sand. February 14th, 1923.

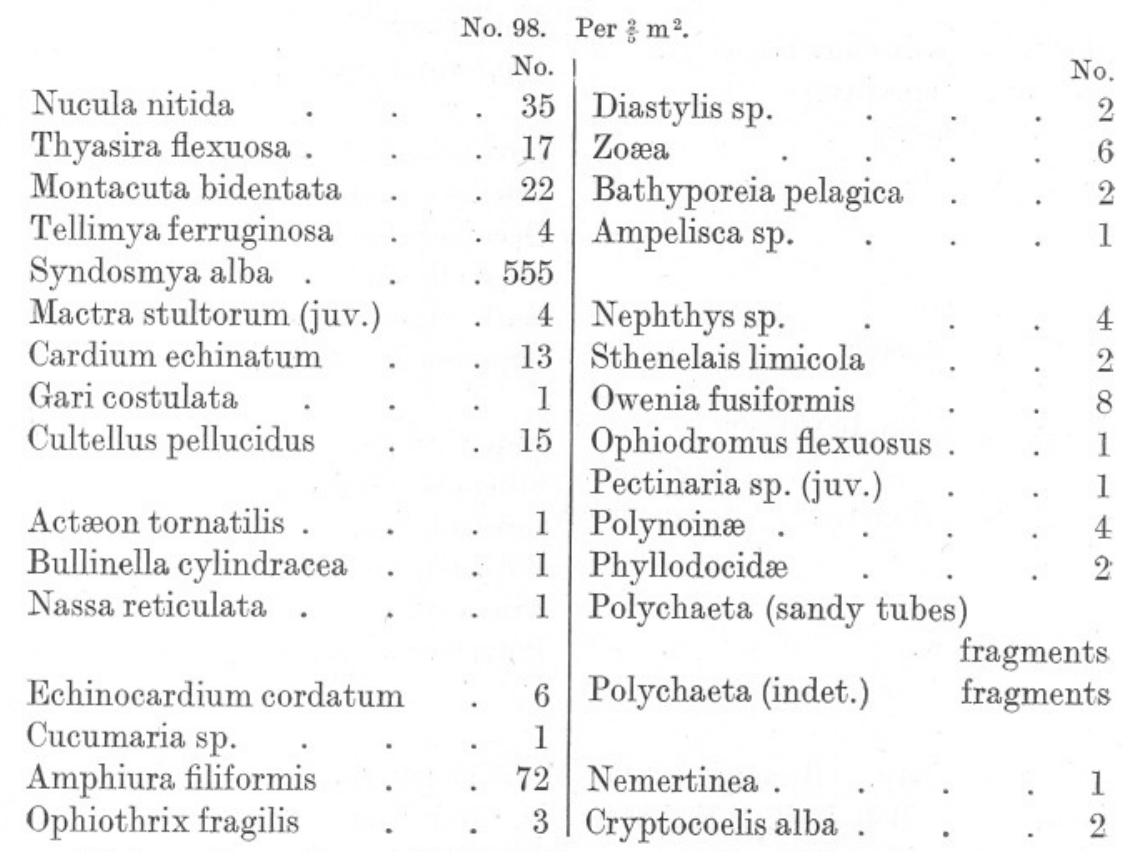

Bigbury Bay. Borough Island, N.E. $\frac{1}{2}$ E. Bolt Tail, S.E. by E.

Silty sand. May 30th, 1923. 
OUTSIDE WATERS. b+Ec+FIL. STATIONS-continued.

\begin{tabular}{|c|c|c|c|c|c|}
\hline Per $\frac{1}{2} m^{2}$ & & No. & Per $\frac{1}{2} m^{2}$. & & No. \\
\hline Nucula nitida & . & 6 & Nucula nitida & 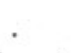 & . 195 \\
\hline Thyasira flexuosa . & . & 1 & Diplodonta rotundata $(j$ & juv.) & \\
\hline Diplodonta rotundàta & . & 1 & Montacuta bidentata & 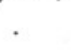 & \\
\hline Syndosmya alba. & 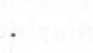 & 88 & lba. & . & 292 \\
\hline Venus ovata. & & 1 & Spisula subtruncata & & \\
\hline Cardium echinatum & . & 2 & ltorum (juv.) & & \\
\hline Cultellus pellucidus & . & 9 & abula & . & \\
\hline Ensis ensis (juv.) . & . & 1 & na (juv.) & & \\
\hline & & & a (et juv.) & . & \\
\hline & & & : & . & \\
\hline Nudibranchiata. & . & 1 & inatum & . & \\
\hline & & & (juv.) & 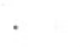 & \\
\hline & & & juv.) & . & \\
\hline Echinocardium cordatu & & 2 & llucidus & ${ }^{\circ}$ & \\
\hline Cucur & . & 1 & Ensis ensis (juv.) . & & \\
\hline filiformis & & 9 & cordatur & & \\
\hline & & & iformis & & \\
\hline Corystes cassivelaunus ( & (juv.) & 1 & (juv.) & . & \\
\hline ıs sp. (juv.) & . & 1 & fragilis & . & \\
\hline Decapoda larvæ . & . & 1 & & & \\
\hline Ampelisca sp. & 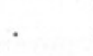 & 1 & v.) & . & \\
\hline & & & arvæ & & \\
\hline & & & Dia & . & \\
\hline Nephthys sp. & & & eia pelagica & . & \\
\hline ssiformis & & 6 & Hippomedon denticulat & & \\
\hline Polynoinæ . & & 1 & & & \\
\hline \multirow{5}{*}{ Polychaeta (indet.) } & & & $\mathrm{Ne}$ & - & \\
\hline & \multirow{2}{*}{\multicolumn{2}{|c|}{$\begin{array}{l}\text { fragments } \\
\text { fragments }\end{array}$}} & is limicola & . & \\
\hline & & & Cirratulidæ . . & . & . \\
\hline & & & Polynoinæ . . & . & \\
\hline & - & 1 & $\begin{array}{l}\text { Aricia sp. } \\
\text { Polychaeta (sandy tube }\end{array}$ & & 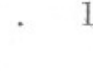 \\
\hline
\end{tabular}

Bigbury Bay. Borough Island, N.E. $\frac{1}{2}$ E. Bolt Tail, S.E. by S. Silty sand. May 30th, 1923.
Bigbury Bay. Borough Island, N. Bolt Tail, S.E. by S. $\frac{1}{4}$ S. May 30th, 1923. 
OUTSIDE WATERS. b+Ee STATIONS.

No. 48. Per $\frac{1}{2} \mathrm{~m}^{2}$.

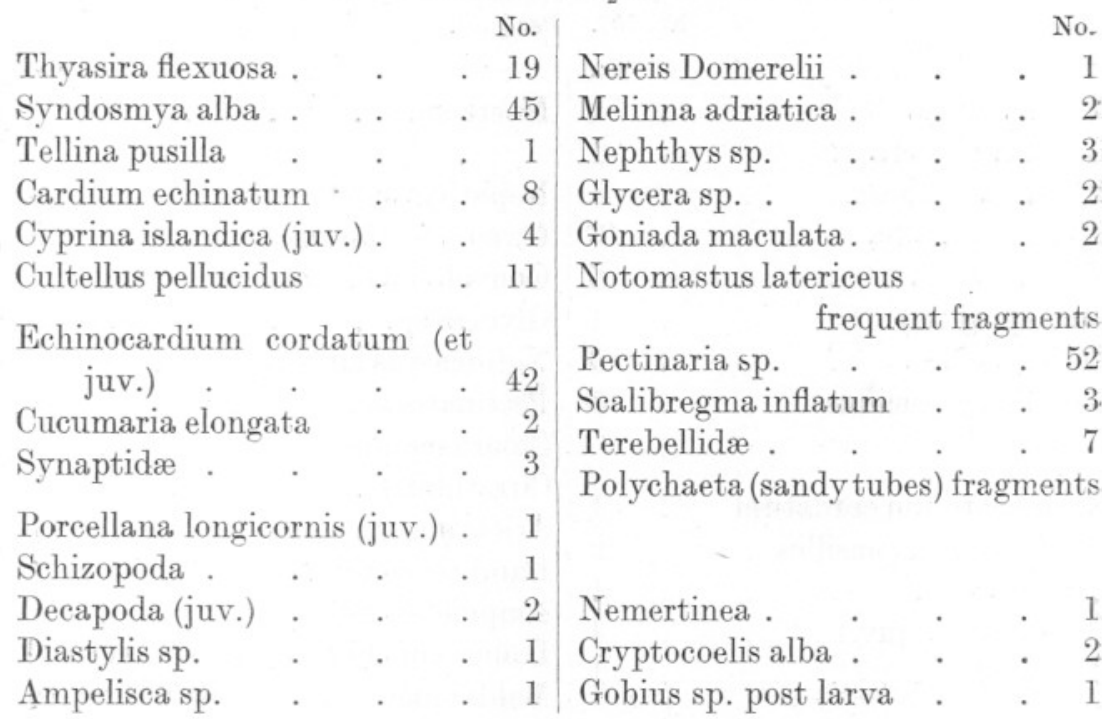

Rame Head, E. Portwrinkle, N. by E. Muddy sand.

July 25th, 1922.

No. 104. $\operatorname{Per} \frac{1}{2} \mathrm{~m}^{2}$.

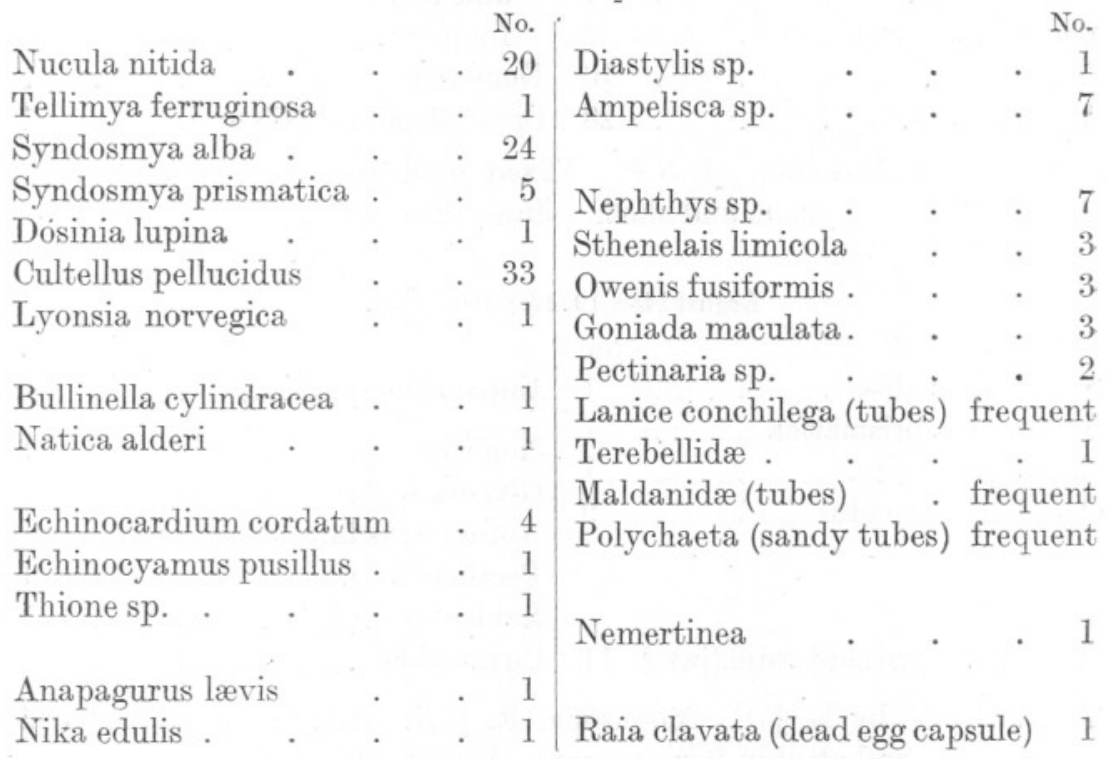

Borough Island, E. Revelstoke Pt., N.E. by N. Silty sand with some flaky shell fragments. June 12th, 1923. 
OUTSIDE WATERS. b+Ec STATIONS-continued,

No. 107. $\operatorname{Per} \frac{1}{2} \mathrm{~m}^{2}$.

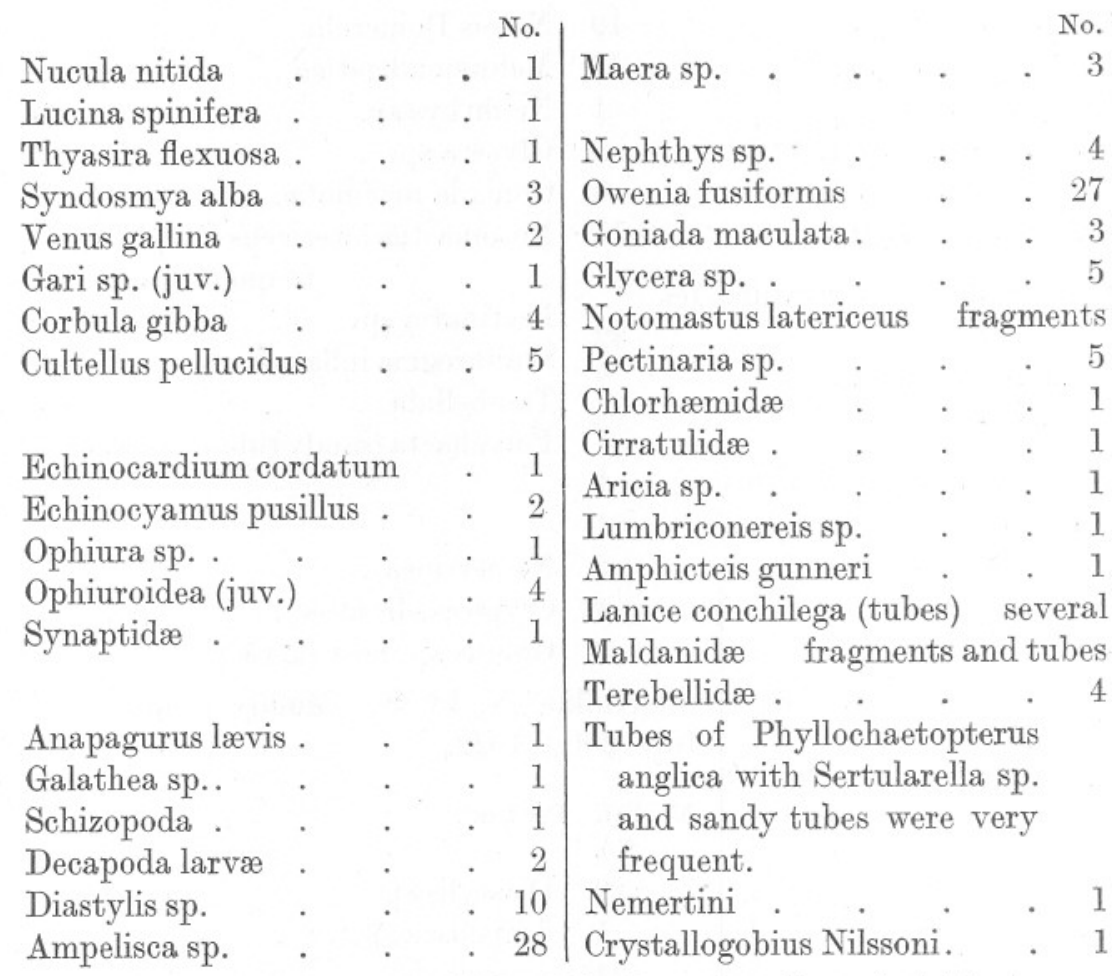

Rame, N. Mewstone, E.N.E. Mixed mud and sand, with some shale and shell. June 12th, 1922.

August 14th, 1922 (e) $\operatorname{Per} \frac{1}{10} \mathrm{~m}^{2}$.

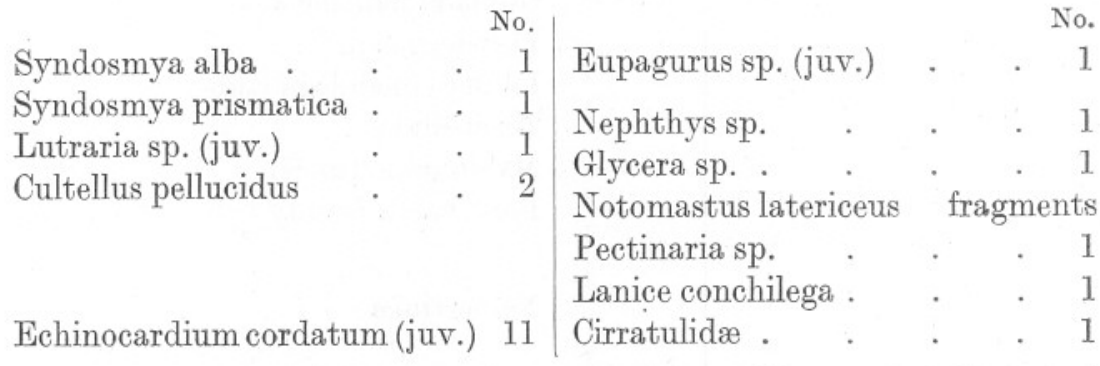

Tregantle, N. by E. $\frac{1}{4}$ E. Mewstone, E. $\frac{1}{2}$ N. Silty sand with gravel and shell in fair amount. August 14th, 1922. 
OUTSIDE WATERS. b+EC STATIONS-continued.

No. 103. $\operatorname{Per} \frac{1}{5} \mathrm{~m}^{2}$.

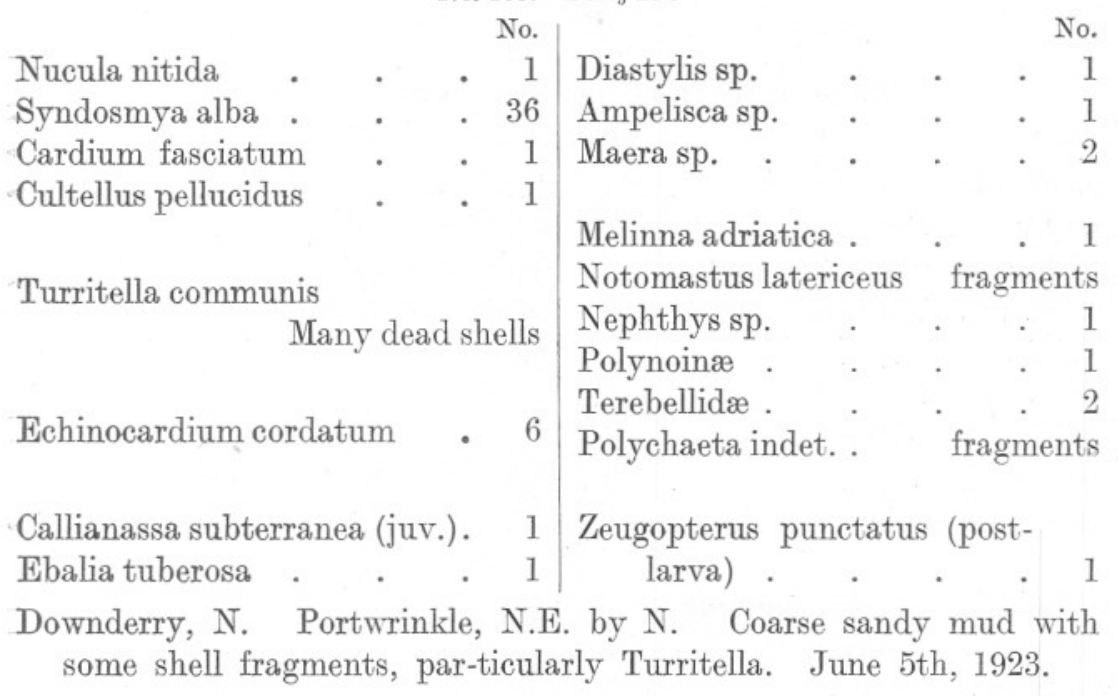

\section{OUTSIDE WATERS. (b) STATIONS.}

No. 50. Per $\frac{1}{2} \mathrm{~m}^{2}$.

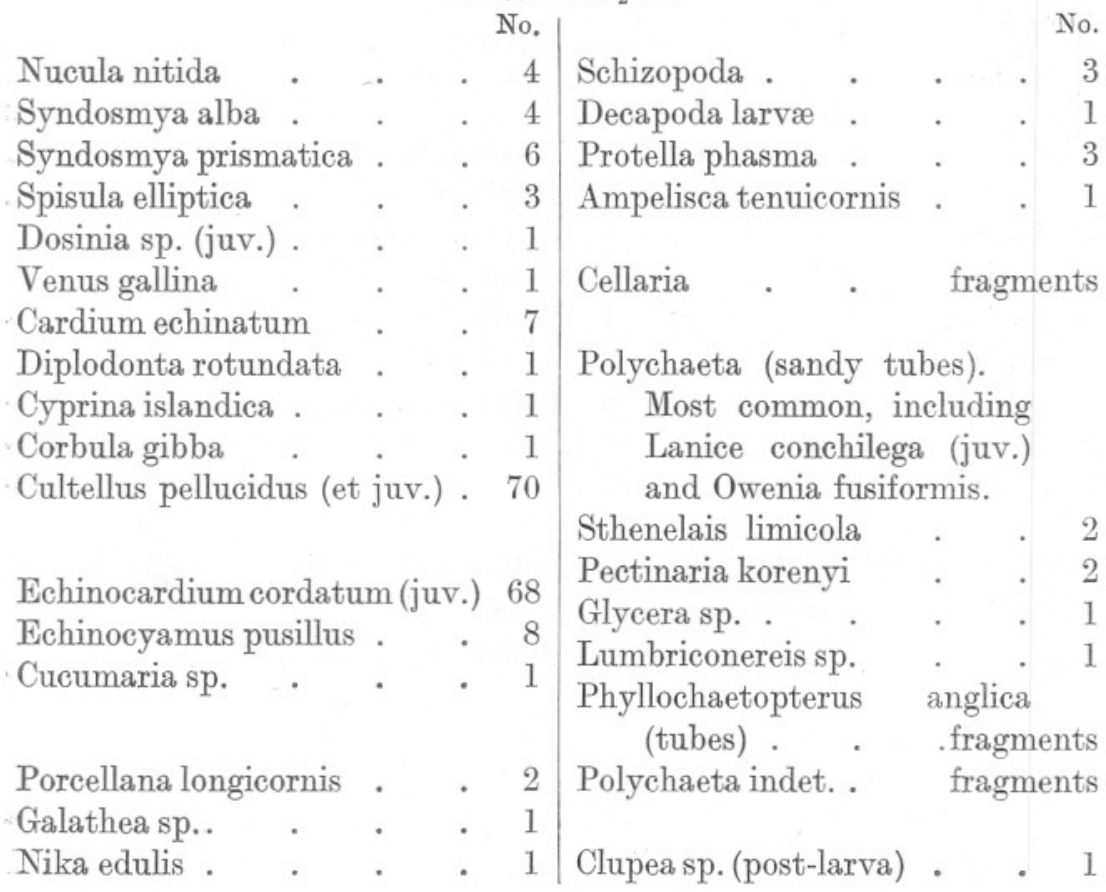

Eddystone, W., 2 miles. Fine silty sand. July 31st, 1922. 


\section{OUTSIDE WATERS. (b) STATIONS-continued.}

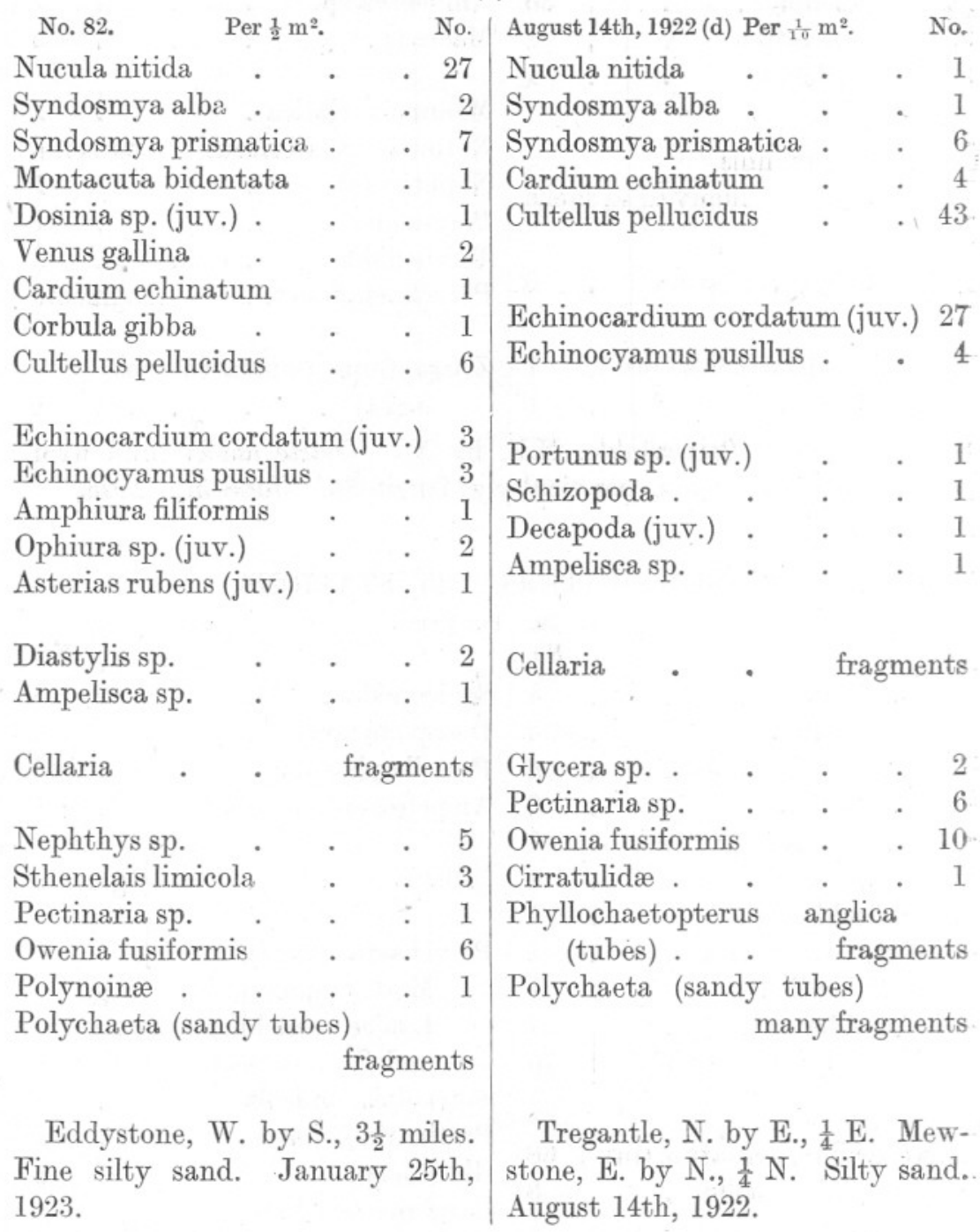


OUTSIDE WATERS. (b) STATIONS-continued.

No. 105. Per $\frac{1}{2} \mathrm{~m}^{2}$.

\begin{tabular}{|c|c|c|c|c|c|c|}
\hline & & & No. & & & No. \\
\hline Nucula nitida & . & . & 1 & Bathyporeia pelagica & . & . \\
\hline Lucina spinifera & . & . & 1 & Monoculodes sp. . & . & . \\
\hline Syndosmya alba & . & . & 1 & Melphidipella macra & . & . \\
\hline Syndosmya prism & iatica & . & 2 & Nototropis vedlomensis & s. & . \\
\hline Cultellus pellucid & & . & 1 & Monoculodes sp. . & . & . \\
\hline Echinocardium co & ordatus & & 2 & Nephthys sp. & . & . \\
\hline Echinocyamus pu & sillus & . & 1 & Sthenelais limicola & . & \\
\hline Luidia sarsi . & . & . & 1 & Lumbriconereis sp. & . & \\
\hline Ophiothrix fragili & & . & 1 & Owenia fusiformis & & \\
\hline & & & & Polynoinæ . . . & & \\
\hline Portunus sp. & . & . & 1 & Polychaeta, tubes & (mostl. & \\
\hline Anapagurus lævis & & ${ }^{\circ}$ & 1 & Lanice conchilega) & . & $\mathrm{ma}$ \\
\hline Ebalia sp. . & . & . & 1 & & & \\
\hline Schizopoda. & . & . & 2 & Nemertinea & . & \\
\hline Decapoda larvæ & . & . & 2 & Cellaria with hydroids & fragl & ment \\
\hline Diastylis sp. & . & . & 5 & Pleuronectes limanda & (post & \\
\hline Caprellidæ . & . & . & 1 & larva) . & . & . \\
\hline Ampelisca sp. & . & . & 6 & Clupea sp. (post-larva) & . & . \\
\hline
\end{tabular}

Rame Head, N.N.W. Eddystone, W. Silty sand with flaky shell fragments. June 12th, 1923.

No. 113. $\operatorname{Per} \frac{1}{2} \mathrm{~m}^{2}$.

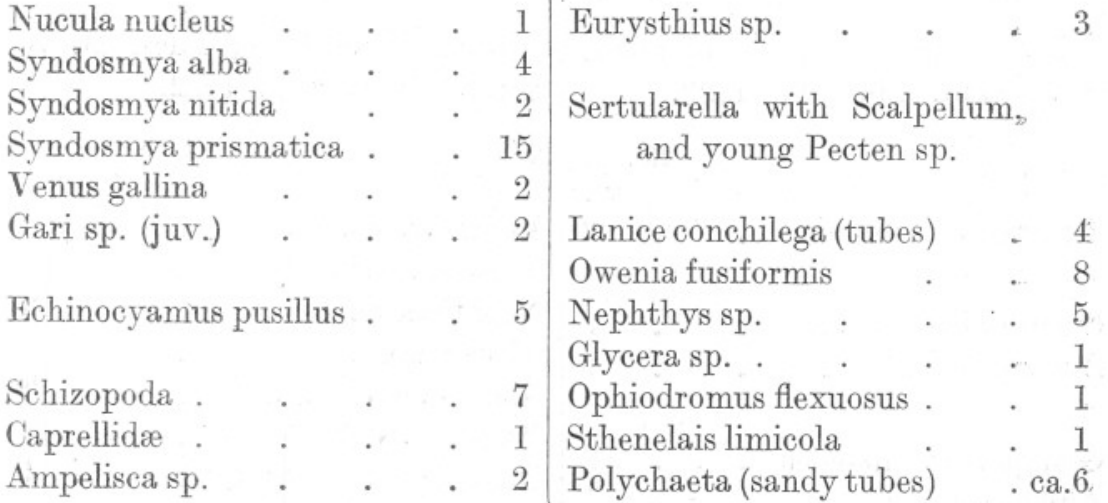

Eddystone, S.S.E. Rame, E. by N. Fine muddy sand. June 26th, 1923. 


\section{OUTSIDE WATERS. EcVG MUD STATIONS.}

No, 5.

Per $1 \mathrm{~m}^{2}$.

No. No. 53.

Per $\frac{3}{10} \mathrm{~m}^{2}$.

No. Syndosmya alba . . . 2

Solecurtus antiquatus . . 1

Corbula gibba $\quad$. $\quad$ • $\quad$. 1

Echinocardium cordatum . 1

Cucumaria elongata . . 3

Cucumaria elongata $\quad . \quad$. 7

Gonoplax rhomboides . . 1

Alphæus ruber . $\quad$. $\quad$. 1

Callianassa subterranea (juv.). 6

Corystes cassivelaunus (juv.) . 4

Porcellana longicornis (juv.) . 2

Diastylis sp. . . . 2

Melinna adriatica . . many

Notomastus latericeus . many

Nephthys sp.

Glycera sp. . . . . 7

Magelona papillicornis . . 4

Aricia sp. . . . . 1

Polychaeta indet. . fragments

Nemertinea . . . . 2

Sagartia sp. . $\quad$. $\quad$. $\quad 1$

Clupea sp. (post-larvæ) . . 3

Pleuronectes limanda (postlarvæ) . . . . 2

Rame Head, E. $\frac{1}{4}$ N., $1 \frac{3}{4}$ miles. Black mud. May 31st, 1922. Synaptidæ . . . . . 1

Alphæus ruber $\quad$. $\quad . \quad$. 1

Callianassa subterranea (juv.). 3

Nika edulis . $\quad . \quad$. $\quad 1$

Galathea sp. (juv.) . . 1

Diastylis sp. $\quad . \quad$. 1

Melinna adriatica . . many

Notomastus latericeus . many

Nephthys sp. . . . . 1

Goniada maculata. $\quad$. 1

Magelona papillicornis . . 13

Scalibregma inflatum . . 13

Ophiodromus flexuosus . . 2

Cirratulidæ . . . . 1

Sthenelais sp. . . . 2

Polynoinæ . . . . . 1

Nemertinea . $\quad . \quad$. 1

Rame Head, E., $1 \frac{1}{2}$ miles. Black mud. August 11th, 1922.

No. 93. $\operatorname{Per} \frac{1}{3} \mathrm{~m}^{2}$.

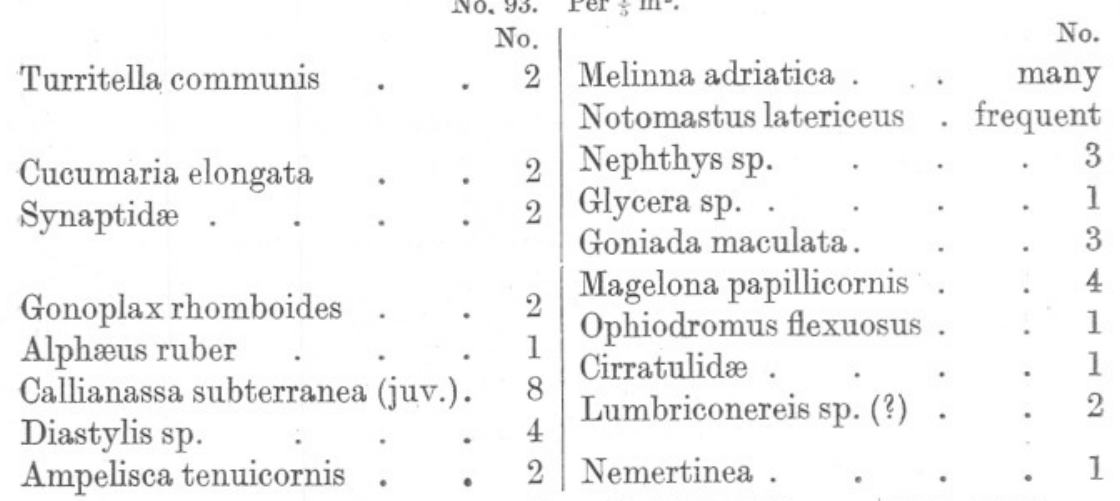

Rame Head, E. $\frac{1}{2}$ N. Tregantle, N. $\frac{1}{2}$ E. February 20 th, 1923. 
OUTSIDE WATERS. VG+TURRITELLA COMMUNIS STATIONS.

No. 96. $\operatorname{Per} \frac{1}{2} \mathrm{~m}^{2}$.

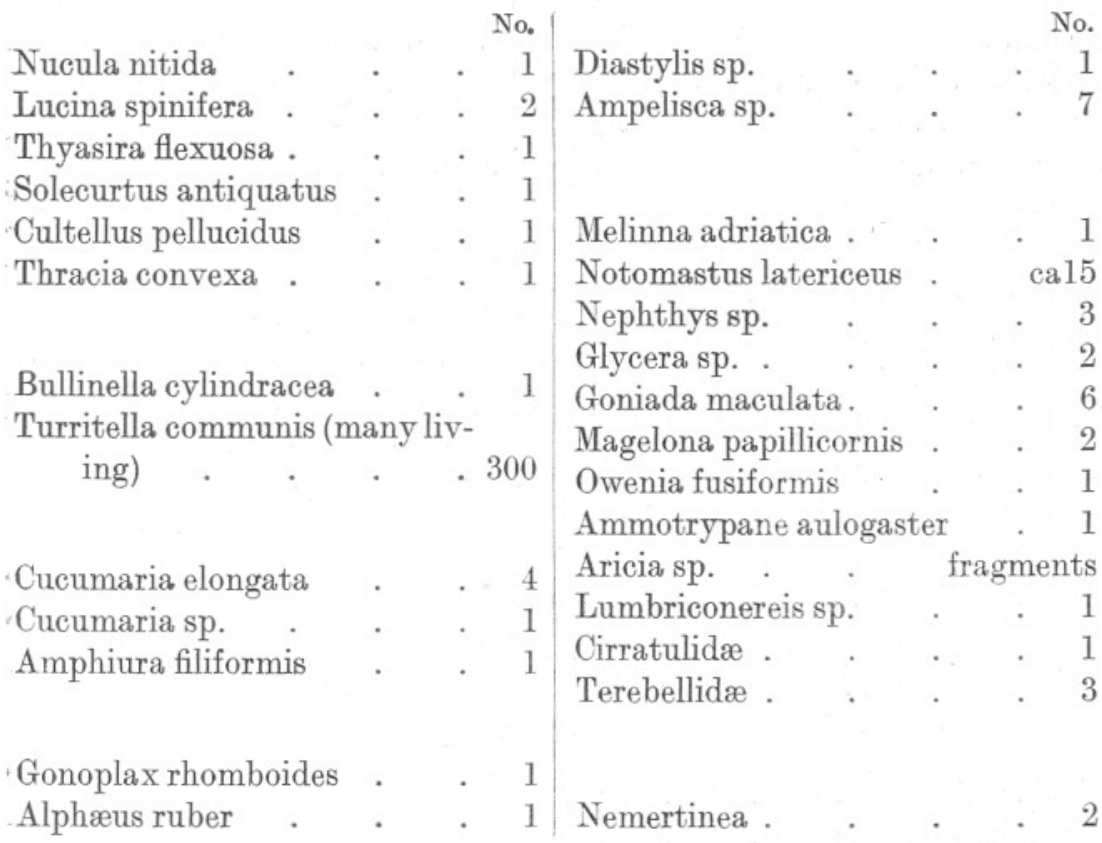

Rame Head, N.E. by E., $\frac{1}{2}$ E., $1 \frac{1}{2}$ miles. Muddy coarse sand with some shell fragments. May 9th, 1923.

No. 84. $\operatorname{Per} \frac{1}{2} \mathrm{~m}^{2}$.

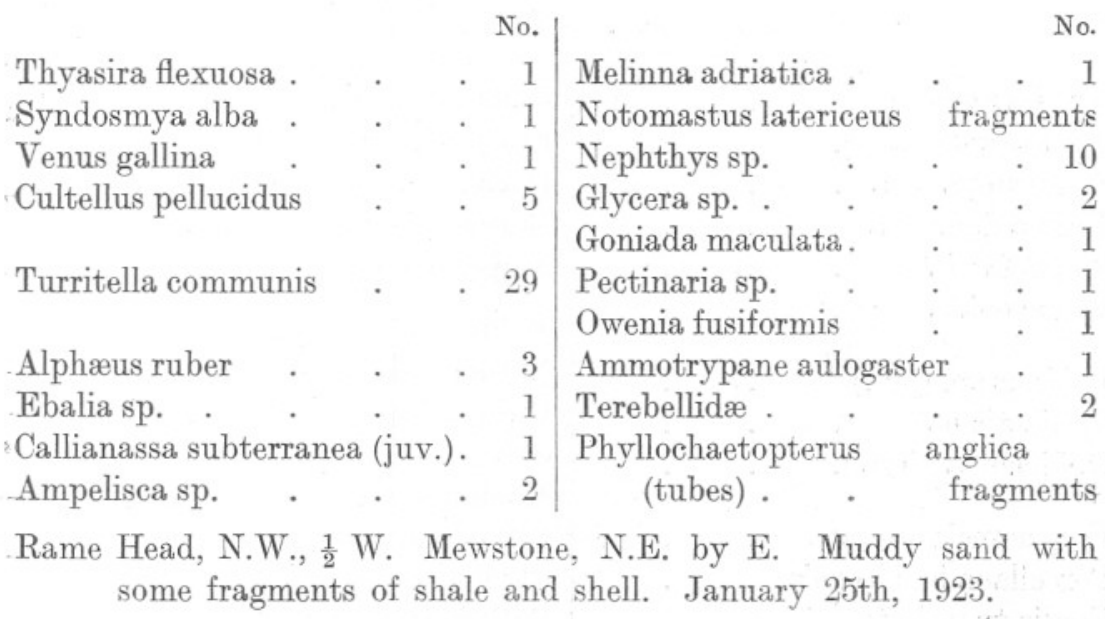


OUTSIDE WATERS. VG+NUCULA NUCLEUS STATIONS. No. 106. Per $\frac{1}{2} \mathrm{~m}^{2}$.

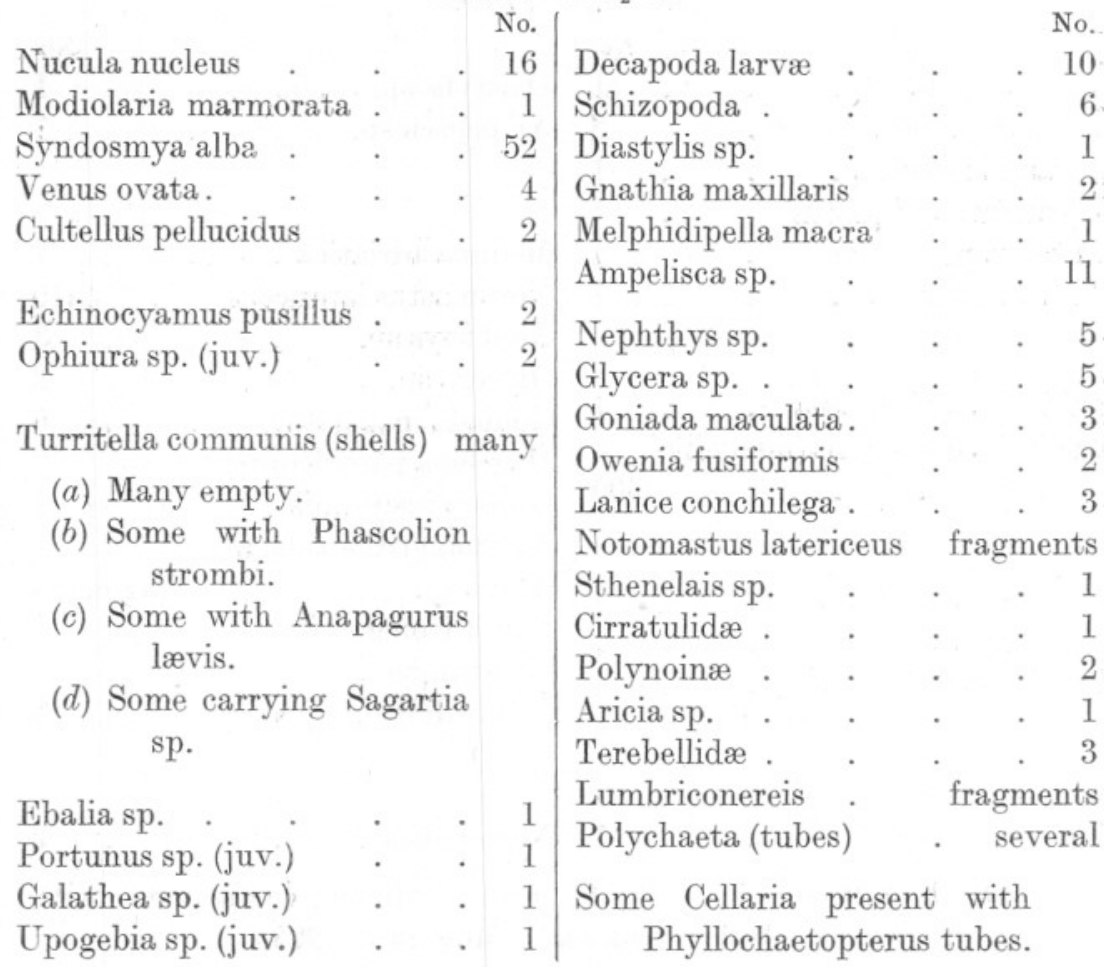

Rame Head, N.N.W. Mewstone, N.E. by N. Muddy sand with broken shells and coarse materials well represented. Dead Turritella shells most numerous. June 12th, 1923.

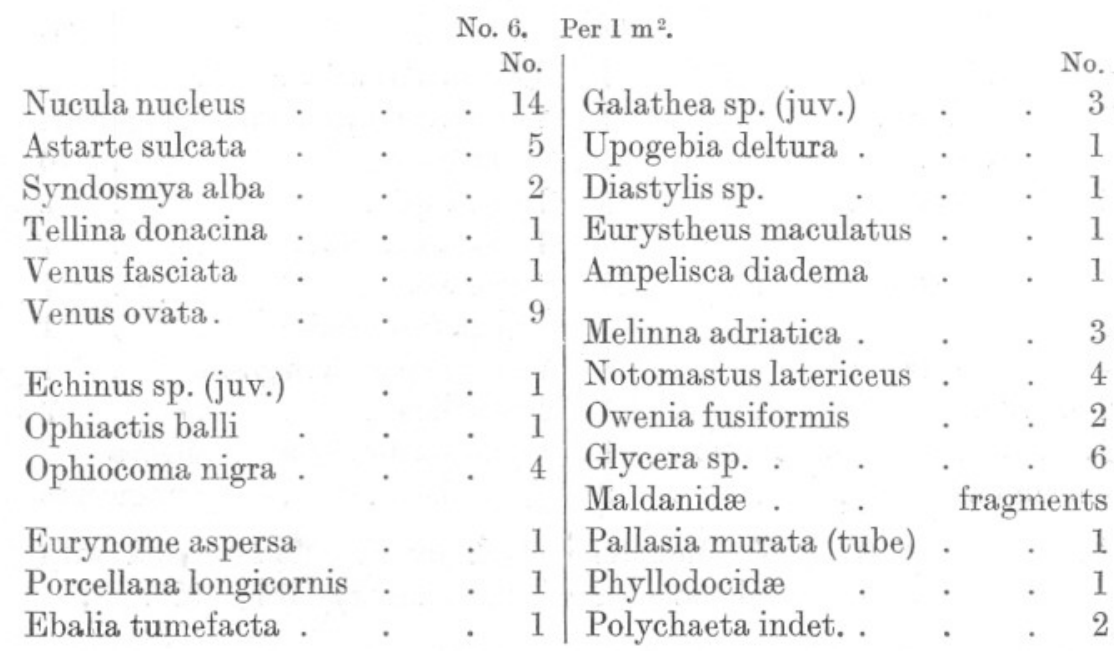

Downderry, N.N.E. Looe, N. by W., $\frac{1}{2}$ W. Muddy shingle. Difficult ground for bottom-sampler. May 31st, 1922. 
MR. J. R. BAKER'S HAULS WITH CONICAL DREDGE.

July-September, 1921.

List of all Species found in Deposits of MUD, with tables of the number of individuals of each species, per sample of 20 litres, in each locality.

\begin{tabular}{|c|c|c|c|c|c|c|}
\hline & & & 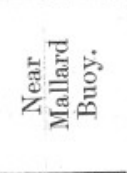 & 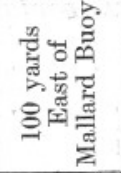 & 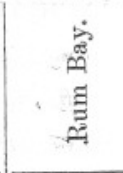 & 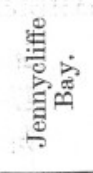 \\
\hline \multicolumn{7}{|l|}{ Coelenterata. } \\
\hline Cerianthus Lloydi & . & . & 3 & 2 & - & - \\
\hline \multicolumn{7}{|l|}{ Polychaeta. } \\
\hline Phyllodoce maculata & . & . & 8 & 2 & 4 & - \\
\hline Nereis sp. & . & . & - & 2 & - & - \\
\hline Nephthys sp. & . & . & 6 & 12 & - & - \\
\hline Lumbriconereis sp. & . & . & 24 & 20 & 5 & 8 \\
\hline Marphysa Belli. & . & $\cdot$ & 6 & - & 1 & - \\
\hline Goniada maculata & . & . & 8 & - & 17 & 18 \\
\hline Glycera sp. & . & . & - & - & 1 & 2 \\
\hline Magelona papillicornis & & . & 4 & - & 2 & - \\
\hline Cirratulus cirratus & . &. & 一 & 4 & - & - \\
\hline Melinna adriatica & . & . & 119 & 96 & c. 130 & 110 \\
\hline Capitella capitata & . & $\cdot$ & - & - & - & 4 \\
\hline \multicolumn{7}{|l|}{ Crustacea. } \\
\hline Orchomene batei. & . & $\cdot$ & - & 2 & - & - \\
\hline Galathea sp. & . & . & - & - & 1 & - \\
\hline Porcellana longicornis & . & . & 1 & - & - & - \\
\hline Macropodia rostratus & . & . & - & - & 1 & 一 \\
\hline Portunus marmoreus & . & . & - & - & 1 & - \\
\hline Pilumnus hirtellus & . & $\cdot$ & - & 2 & - & - \\
\hline \multicolumn{7}{|l|}{ GASTROPODA. } \\
\hline Philine aperta . & . & . & - & 6 & 22 & 一 \\
\hline \multicolumn{7}{|l|}{ LAMELLIBRANCHIATA. } \\
\hline Nucula nitida . & . & . & 2 & - & - & 2 \\
\hline Glycimeris glycimeris & . & . & - & 2 & - & - \\
\hline Astarte sp. & . & $\cdot$ & 1 & - & - & - \\
\hline
\end{tabular}


MR. J. R. BAKER'S HAULS WITH CONICAL DREDGE-continued.

\begin{tabular}{|c|c|c|c|c|c|c|}
\hline & & & 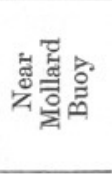 & 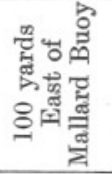 & 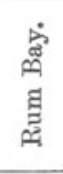 & 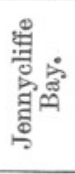 \\
\hline \multicolumn{7}{|c|}{ LAMELLIBRANCHIATA (contd.). } \\
\hline Lucina borealis . & . & . & - & 2 & 1 & - \\
\hline Thyasira flexuosa & . & . & 12 & 2 & 2 & 20 \\
\hline Syndosmya nitida & . & . & 2 & 16 & 4 & 6 \\
\hline Syndosmya alba. & . & . & - & 18 & 1 & 2 \\
\hline Spisula elliptica & . & . & - & 4 & - & - \\
\hline Dosinia lupina . & . & . & - & 2 & - & - \\
\hline Venus gallina & . & . & 5 & 8 & 4 & - \\
\hline Tapes sp. . . & . & . & 2 & 6 & - & - \\
\hline Cardium sp. & . & . & - & 2 & 1 & - \\
\hline Corbula gibba & . & . & - & 2 & - & - \\
\hline Solecvrtus antiquatus & . & . & - & 2 & - & 2 \\
\hline Cultellus pellucidus & . & . & 1 & 4 & 5 & - \\
\hline \multicolumn{7}{|l|}{ OPHIUROIDEA. } \\
\hline Ophiura albida . & . & $\cdot$ & - & - & 1 & - \\
\hline
\end{tabular}

List of all Species found In Deposits of SAND, with tables of the number of individuals of each species, per sample of 20 litres, in each locality.

\begin{tabular}{|c|c|c|c|c|c|c|}
\hline & & 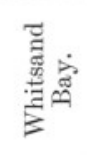 & 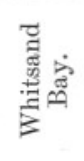 & 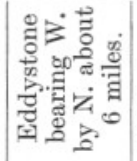 & 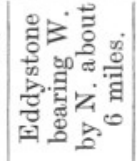 & 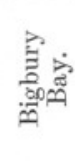 \\
\hline \multicolumn{7}{|l|}{ Polychaeta. } \\
\hline Sthenelais boa & & - & - & - & - & 5 \\
\hline Nephthys sp. & & 6 & 13 & 3 & 6 & 7 \\
\hline Lumbriconereis sp. & . & - & - & - & - & 1 \\
\hline Glycera siphonostoma & . & - & 一 & 3 & 4 & - \\
\hline Owenia fusiformis. & . & - & - & 3 & - & - \\
\hline Lanice conchilega. & & - & - & 4 & 2 & - \\
\hline Capitella capitata . & . & 2 & - & - & - & - \\
\hline Nicomache lumbricalis & . & - & - & 1 & - & - \\
\hline
\end{tabular}


MR. J. R. BAKER'S HAULS WITH CONICAL DREDGE-continued.

\begin{tabular}{|c|c|c|c|c|c|c|c|}
\hline & & & 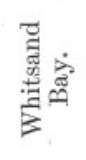 & 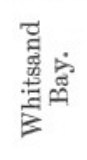 & 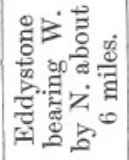 & 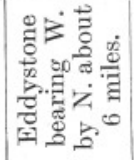 & 密完 \\
\hline \multicolumn{8}{|l|}{ Crustacea. } \\
\hline Ampelisca spinipes & & . & 2 & - & - & 2 & - \\
\hline Ampelisca tenuicorr & nis & . & - & - & 1 & 2 & 1 \\
\hline Maera othonis & . & . & - & - & - & 2 & - \\
\hline Bathyporeia norveg & ica & . & 12 & - & - & - & - \\
\hline Hippomedon dentic & culatus & & - & 1 & - & - & - \\
\hline Siphonocoeies Colle & etti & . & - & - & 1 & - & - \\
\hline Iphinoe trispinosa & & . & 2 & 3 & - & - & 1 \\
\hline Nika edulis & . & . & - & - & 1 & - & - \\
\hline Galathea strigosa & . & . & - & - & 1 & 6 & - \\
\hline Porcellana longicor & mis & . & - & - & 1 & - & - \\
\hline Portunus pusillus & . & . & - & - & 1 & - & - \\
\hline \multicolumn{8}{|l|}{ Gastropoda. } \\
\hline Nassa reticulata & . & . & - & 1 & - & - & - \\
\hline \multicolumn{8}{|l|}{ LAMELLIBRANCHIATA. } \\
\hline Donax vittatus & . & . & 2 & - & - & - & - \\
\hline Pecten sp. juv. & . & . & 一 & - & 1 & - & - \\
\hline Lucina borealis & . & . & - & - & - & 2 & - \\
\hline Tellina donacina & . & . & - & - & 1 & - & - \\
\hline Syndosmya prismat & itica & . & - & - & - & 2 & - \\
\hline Spisula solida & . & . & - & - & - & - & 1 \\
\hline Meretrix chione & . & . & 2 & - & - & - & - \\
\hline Dosinia lupina & . & . & - & - & 2 & 6 & - \\
\hline Venus gallina & . & . & 2 & 3 & - & 6 & 7 \\
\hline Corbula gibba & . & . & - & - & - & - & 1 \\
\hline Ensisensis. & . & . & - & 1 & - & - & 3 \\
\hline Cultellus pellucidus & & . & - & - & 3 & 2 & 10 \\
\hline \multicolumn{8}{|l|}{ ECHINODERMATA. } \\
\hline Amphiura filiformi & & $\cdot$ & 一 & - & 1 & - & - \\
\hline Ophiura albida & - & . & - & 一 & - & 4 & 2 \\
\hline Echinocardium sp. & & . & - & 1 & 1 & - & 1 \\
\hline Cucumaria sp. & . & . & - & - & 1 & - & - \\
\hline
\end{tabular}


List of all Species found in Deposits of SHELL GRAVEL, with tables of the number of individuals of each species, per sample of 20 litres, in each locality.

\begin{tabular}{|c|c|c|c|c|c|c|}
\hline . & & & 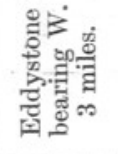 & 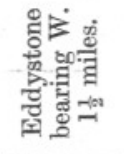 & 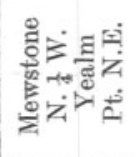 & 焉 \\
\hline \multicolumn{7}{|l|}{ Polychaeta. } \\
\hline Harmotho setosissima & & . & - & 2 & 一 & 2 \\
\hline Nephthys sp. . & . & . & - & 一 & - & 2 \\
\hline Lumbriconereis sp. & . & . & 1 & - & - & - \\
\hline Glycera lapidum & . & . & - & 2 & 1 & 2 \\
\hline Glycera Ehlersi . & . & . & - & 2 & - & - \\
\hline Glycera siphonostoma . & . & . & - & - & 1 & - \\
\hline Hyalonøcia sicula & . & . & 2 & - & 1 & - \\
\hline \multicolumn{7}{|l|}{ Crustacea. } \\
\hline Maera othonis . & . & . & - & 4 & - & - \\
\hline Conilera cylindracea. & . & . & 1 & - & - & 2 \\
\hline Eulima polita . & . & . & 一 & - & 1 & - \\
\hline Galathea sp. juv. & . & . & - & 6 & - & - \\
\hline Porcellana longicornis . & . & . & 1 & 4 & - & 2 \\
\hline Craspedochilus onyx . & . & . & - & 2 & - & - \\
\hline Trophon muricatus & . & . & - & 2 & - & - \\
\hline \multicolumn{7}{|l|}{ LAMELLIBRANCHIATA. } \\
\hline Nucula sp. $\quad$. & . & . & 1 & - & 3 & - \\
\hline Glycimeris glycimeris & . &. & 1 & 4 & - & 一 \\
\hline Lucina borealis . & . & . & - & 2 & - & - \\
\hline Tellina pusilla . & . & . & - & - & - & 4 \\
\hline Dosinialupina . & . & . & - & - & 1 & 10 \\
\hline Venus fasciata . & . & . & 3 & 4 & - & 4 \\
\hline Gouldia minima & . & . & - & - & - & 2 \\
\hline Tapes sp. . & . & . & 1 & 2 & - & - \\
\hline Cardium sp. juv. & . & . & - & - & - & 4 \\
\hline Psammobia tellinella & . & . & 1 & - & 1 & 1 \\
\hline Corbula gibba . & . & . & - & - & - & 1 \\
\hline \multicolumn{7}{|l|}{ ECHINODERMATA. } \\
\hline Ophiura albida . & . & . & - & - & 1 & - \\
\hline Ophiothrix fragilis & . & . & - & - & 一 & 1 \\
\hline Echinus sp. juv. & . & . & 1 & - & - & - \\
\hline Echinocyamus pusillus & & . & 1 & - & 1 & 2 \\
\hline \multicolumn{7}{|l|}{ Chordata. } \\
\hline Amphioxus lanceolatus & & . & 4 & - & 2 & - \\
\hline
\end{tabular}

